\title{
Exstasis divini amoris
}

\author{
The Macrocosm
}

Broadly speaking, following Propositions 20-21, Berthold demarcated four internally ordered ranks (maneries) within Proclus' cosmology of natural providence: (1) that of the One, which includes the gods or primordial causes; (2) of Intellect, which includes everything beneath the primordial causes down to and excluding heavenly souls; (3) of Soul, including both heavenly ("whole") and human ("partial") souls; (4) and of Body or Nature, embracing the world of generation or becoming. ${ }^{1}$ He largely but not exclusively interpreted the interactions within and between these levels through a theory of causality he adapted from Dietrich of Freiberg, who had distinguished between three kinds of causes (essential, substantial, and accidental). ${ }^{2}$ Directly in line with Dietrich, Berthold also maintained that, in any of these three kinds of causes, one finds that an "interior transfusion" is the principle of any activity directed to the outside - this is true of all four maneries, of bodies as much as of the Trinity. ${ }^{3}$ But in a significant departure from Dietrich, Berthold maintained that only a Platonic perspective on causality and universality, which places the One and the Good at the foundation of the cosmos, can adequately account for this interior dynamism and the order that flows from it. Therefore, we must first grasp the fundamental distinction in Berthold's view between the Aristotelian and the Platonic understandings of first principles in metaphysics and theology, with which he began his remarks on Proposition 1 of the Elementatio. Upon that basis we shall find that the philosophy of the Expositio can indeed be regarded, as Loris Sturlese remarked, as a "thinking through" of Dietrich's metaphysics within the context of the Elementatio theologica and Berthold's understanding of the revision of first principles it required. ${ }^{4}$ The result of this, as we glimpsed in Berthold's subtle but decisive transformation of Dietrich's

1 On the political and literary origins of the term maneries, see D. Calma, "Maneries", in I. Atucha et al. (eds), Mots médiévaux offerts à Ruedi Imbach (Porto: Fédération Internationale des Instituts d'Études Médiévales, 2011), p. 433-444.

2 Dietrich of Freiberg, De visione beatifica, 3.2.9.4, p. 9o, l. 2 - p. 93, l. 104.

3 Dietrich of Freiberg, De intellectu et intelligibili, I.5.1 - I.9.2, p. 139, l. 59 - p. 142, 1. 93.

4 Sturlese, Homo divinus, p. 143: "Als Berthold die Entscheidung traf, die Philosophie Dietrichs in Form eines Prokloskommentars zu durchdenken [...]". 
methodology and theology in the Expositio tituli and the Praeambulum, was a philosophy that placed the ecstatic before the substantial and the non-reflexive prior to reflexivity both in the cosmos and in the human soul.

By the end of the Praeambulum it became clear that Berthold was less interested in drawing a boundary between Christianity and pagan Platonism than between the Platonic divine science and Aristotelian metaphysics. This contrast between the two traditions is carried on as a leitmotif of the Expositio. ${ }^{5}$ The problem, as we will now see, was not with Aristotle's philosophy as a whole, but rather with its account of the immaterial world. ${ }^{6}$ Berthold largely accepted Aristotelian natural philosophy as it applies to the world of becoming. But when the relationship of potency and act in that domain was extended to apply to the order of the separate substances, according to Berthold the consequences were dire: metaphysics became content to function as a sort of logical game that had jettisoned any attempt to reach the realities themselves or to make its practitioner disposed to receive them. For Berthold, realising Aristotle's ambitions for a science of the separate substances, whose transitory contemplation is the highest felicity in this life, required a revision in first principles.

At the outset of his commentary on Proposition 1 ("Every plurality in some way participates the One"), ${ }^{7}$ Berthold announced that Plato and Aristotle have opposed ways of accounting for the origin of distinction and plurality (ratio distinguendi). ${ }^{8}$ According to Berthold, Aristotle's mistake was not that "act separates and distinguishes" (Metaphysics VII.13, 1039a7) but the belief that this was universally the case. As the Dominican presented it, Aristotle arrived at this position through a thoroughly physicalist orientation to the question of substance: "in the foundation of nature, namely prime matter, nothing is

5 Passages may be classified according to the following themes: on abstract metaphysics and real divine science $(1 \mathrm{~A}, 11 \mathrm{~A})$; on abstract and separate universals $(16 \mathrm{D}, 67 \mathrm{C}, 135 \mathrm{~K}$, and $136 \mathrm{D}-\mathrm{E})$; on the soul as self-moving (17A-B); on the ideas $(177 \mathrm{H}$ and $178 \mathrm{~B})$.

6 For a similar criticism of Aristotle made by Proclus, unbeknownst to Berthold, see C. Steel, "Why Should We Prefer Plato's Timaeus to Aristotle's Physics? Proclus' Critique of Aristotle's Causal Explanation of the Physical World", in Bulletin of the Institute of Classical Studies. Supplement 78(2003), p. 175-187.

7 Proclus, Elementatio theologica, prop. 1, p. 3, l. 1: Omnis multitudo participat aliqualiter uno.

8 Berthold of Moosburg, Expositio, 1A, p. 72, 1. 48 - p. 74, l. 125. 
distinct". If act always determines potency, then prime matter must be "one by privation" of act.

In Berthold's reconstruction of the Aristotelian approach, we move from this assumption about act and potency to a metaphysical reduction to being as the first principle. Since act is in some sense "opposed" to potency, Berthold presented what he described as a summary of Aristotle's arguments in Metaphysics $\mathrm{x}$ about the most fundamental opposition or contradiction, from which arise the notions of act and potency as well as "one" and "many". ${ }^{9}$ His tacit and direct source here was Dietrich of Freiberg's De natura contrariorum, which used Aristotle's text extensively to explain the nature of contraries that are the basis of physical change in the elements apprehended by our senses. ${ }^{10}$

According to Aristotle, the opposition of potency and act is logically dependent on the more fundamental opposition of privation and positive possession (privatio et habitus). To understand what Berthold meant by this, we can look more closely at Dietrich's analysis of Aristotle's arguments. ${ }^{11}$ Contraries are what differ maximally within a genus, which is "the common nature" that the notion of contrariety presupposes as the basis for comparison. While a genus as a common nature implies some kind of formal content, it is also capable of further determination by differentiae that are more formal than it; the genus thus becomes "the subject", broadly speaking, of affirmation and negation. The genus in this perspective is an aptitude for either affirmation or negation; or, in other words, it is what positively relates to the common term in question ( $\mathrm{hab}$ itus) or what is remote from it (privatio). This is what Berthold assumed when he wrote that this "first contrariety" of privation and habitus has "originated from the first opposition as such" which (following Dietrich) he identified as contradiction (contradictio) or affirmation and negation in a given subject. "Contradiction" is more absolute than "contrariety" because the latter admits of degrees and intermediary states, and these presuppose contradiction as their measure. With contradiction, then, we arrive at the "first and original reason of every distinction", namely, "the contradictory opposition of being to non-being as such". Tellingly, Berthold did not include the portion of Dietrich's argument emphasising that affirmation and negation must not be understood in a strictly propositional or logical sense, but as "real, simple intentions concerning being" - for Dietrich, only in this way can they give rise to the real

9 Berthold of Moosburg, Expositio, 1A, p. 73, l. 88-89.

10 Dietrich of Freiberg, De natura contrariorum, 1.1, p. 83, 1. 2-3: Considerandum de vocatis elementis, inquantum invenitur in eis principium transmutationis physicae [...].

11 Dietrich of Freiberg, De natura contrariorum, 2.1-3.5, p. 83, l. 12 - p. 85, l. 91. 
intentions of "one" and "many".12 But this was not the Aristotle Berthold was resisting.

Berthold continued to rely on Dietrich to explain how, for Aristotle, the notions of "one" and "many" are "the primary modes of being" deduced from the absolute opposition (that is, the contradiction of affirmation and negation or of being and non-being). The notion of "one" (ratio unius) removes the distinction (removetur distinctio) that occurs between being and non-being as such, since what is one is simultaneously "indistinct in itself and distinct from anything else". ${ }^{13}$ That is, what is indistinct in itself contains no division or distance (remotio). In this sense the distinction that is effected by the opposition of being and non-being is removed or negated. But when the ratio unius is presupposed and the distinction of affirmation and negation is posited (ponitur distinctio), then we have the notion of "many" (ratio multi). For "many" implies that there is one thing and another thing, and that this one is not that one.

Again following Dietrich, Berthold clarified that the opposition of affirmation and negation is found in every intention of being. Therefore, it is not "exceeded by being itself" but is coterminous with it, for being is not a genus. So too the first modes that arise from the opposition of "one" and "many" do not divide any "common intention" but are "a simple enumeration of beings". This implies that the amplitude of the ratio unius is coextensive to that of the ratio entis. However, in any determinate genus of being, the modes that arise from the opposition of privation and habitus are themselves determinate. Three examples of this are given by Berthold in 1A. (1) If the formal intention of the genus is something analogically common, as "healthy" is said of an animal and of urine, then we speak of the determinate modes of identity and diversity (diversitas). Dietrich had argued that this term "diversity" is appropriate because, in the case of analogical commonality, the intention of being is not truly one (non tamen vere una), since the terms do not really and truly share the common nature..$^{14}(2)$ If the formal intention of the genus is univocally common, then we have a clear case of the privation and habitus of a common nature, whose modes are identity and "difference" (differentia). For example, plants and animals univocally share the identical genus of "animated body"

12 Cf. Dietrich of Freiberg, De natura contrariorum, 13.1, p. 93, l. 47-55. Cf. V. Decaix, "Les transcendentaux et l'un. Dietrich de Freiberg à l'école de Thomas d'Aquin", in Bochumer philosophisches Jahrbuch für Antike und Mittelalter 16(2013), p. 146-162, at p. 154-16o, on the similarities of Dietrich's derivation of the notion of "one" to the approach taken by Aquinas.

13 Cf. Dietrich of Freiberg, De natura contrariorum, 16.2, p. 95, l. 30-35.

14 Dietrich of Freiberg, De natura contrariorum, 19.2-20.1, p. 97, 1. 105 - p. 98, 1. 10. 
but "differ" in species. ${ }^{15}$ (3) Finally, if privation is somehow intrinsic to one pair of the opposition, as the colour black is inherently the privation of the colour white, then we speak of the determinate modes of "likeness" and "contrariety" (similitudo, contrarietas). ${ }^{16}$

Berthold included these examples of determinate genera and their modes because they provided a catalogue of the kinds of unity and plurality that populate a world in which act or habitus always determines potency. Plato, however, followed another path (via) concerning the origin of plurality:

Although [Plato] conceded that distinction is the formal cause of plurality, yet according to him act only distinguishes in material things, and not everywhere, that is, not in the entire universe of things. ${ }^{17}$

In material things, it is indeed the case that what is more common - either in reality (prime matter) or in reason, whether it be analogical (being as such) or univocal - is more potential and is distinguished or "determined" by act and specific differentiae. But it is otherwise in the immaterial order, where the more common or "more universal" is more actual (activius); here, we are in the domain of the universality of separation (universalitas separationis) or the theological universal (universale theologicum), while regarding material things we speak only of the universality of predication (universalitas praedicationis) or the logical universal (universale logicum).

This is the fulcrum around which the discord of Plato and Aristotle turns in the Expositio. Berthold explained that Aristotle, failing to observe this distinction of universality, understood being (ens) as a transcendental (transcendens) and "the first of all intentions", which does not have existence outside the soul (non habens esse in rerum natura extra animam). He reached the priority of ens by a logical abstraction according to the dictates of the universality of predication. Now, a transcendental is an intention that is not confined to a particular genus or category. ${ }^{18}$ As we have seen, since the notions of "one" and "many" are not confined to any determinate genus, they too for Aristotle must be transcendentals, which do not exist outside the soul (transcendentia, quarum esse etiam

15 Dietrich of Freiberg, De natura contrariorum, 21.1-23.2, p. 98, 1. 16 - p. 99, l. 42.

16 Dietrich of Freiberg, De natura contrariorum, 24.1-3, p. 99, l. 50 - p. 10o, l. 71.

17 Berthold of Moosburg, Expositio, 1A, p. 73, l. 90-94: Plato vero alia via incedit circa multitudinis originem, qui, licet concedat distinctionem esse formalem causam multitudinis, tamen actus secundum eum non ubique, hoc est in tota rerum universitate, distinguit nisi in solis materialibus.

Berthold of Moosburg, Expositio, 11A, p. 185, l. 24-25; 136E, p. 7, l. 140 - p. 8, l. 161. 
non est extra animam). The entire deduction of the modes of the opposition of affirmation and negation - metaphysics as the science of being and its properties - was thus regarded by Berthold as a purely logical exercise, which remains valid if its application is restricted to those boundaries. For Berthold, unlike for Dietrich, Aristotle's deduction in Metaphysics x tells us nothing about the real origin of diversity. This is why it was necessary to follow Plato's more counterintuitive approach. As Eustratius reported, Plato posited the ineffable Good as the common cause of all things, prior to the difference of being and non-being (super ens et non ens). Distinction arises from the fact that what comes from the principle (principiatum) its less actual than its source, and to that extent it falls short (recessum) of the first principle as such. ${ }^{19}$

In Proposition 11 ("All beings proceed from one first cause"), ${ }^{20}$ we find a convergent account of the Aristotelian approach to first principles. This time the transcendentals were more directly Berthold's focus. According to Berthold, Aristotle held that being (ens) is "the first and most formal of all intentions" because it is the last in "resolution."21 As Wouter Goris has shown, Berthold's notion of the resolution to ens moved through two levels: the first followed the argument of the Posterior Analytics to reach the principle of non-contradiction, and another taken from Avicenna that led to the non-complex first principle of knowing. ${ }^{22}$ As in Proposition 1, Berthold aimed to prove that Aristotle arrived to the primacy of ens through a reflection on the first principles of logical analysis, always with the assumption that act determines potency. With this logical primacy of being, the other transcendentals, "one, good, true, thing, and something" are seen further determinations of or additions to the notion of ens. These additions, Berthold never tired of repeating, are purely rational and have their reality only in the understanding.

Berthold then drew the critical conclusion that haunts Aristotle throughout the Expositio, turning against him the words of Averroes' commentary on

19 A similar argument about act and potency, which used the language of accessus and recessus and appealed explicitly to the Elementatio theologica, was made by Godfrey of Fontaines in favour the real identity of essence and existence in the separate substances. See Wippel, The Metaphysical Thought of Godfrey of Fontaines, p. 9o-97.

20 Proclus, Elementatio theologica, prop. 11, p. 8, l. 1: Omnia entia procedunt ab una causa prima.

21 Berthold of Moosburg, Expositio, 11A, p. 185, l. 28 - p. 186, l. 53. This terminology derived from Dietrich: De ente et essentia, ed. R. Imbach, in Opera omnia, vol. 2, I.2.2, p. 28, l. 78-78; id., De natura contrariorum, 15.1, p. 94, 1. 3-4; id., De quiditatibus entium, 1.3, p. 99, 1. 12-13; id., De origine rerum praedicamentalium, 1.7, p. 139, 1. 75-76.

22 W. Goris, "Das Gute als Ersterkanntes bei Berthold von Moosburg", in W. Goris (ed.), Die Metaphysik und das Gute. Aufsätze zu ihrem Verhältnis in Antike und Mittelalter, Jan A. Aertsen zu Ehren (Leuven: Peeters, 1999), p. 139-172, at p. 151-156. 
Metaphysics x: "being" and "one" are "universal categories which do not have being outside the soul". ${ }^{23}$ In the judgement of Jan Aertsen, this is the most remarkable aspect of Berthold's account of Aristotle. ${ }^{24}$ When confronted with Aristotle's explicit declaration that "good" and "bad" are in things (bonum et malum sunt in rebus), Berthold conceded that, while this is true of things subjectively (subiective), the transcendental notions of "good" and "bad" themselves for Aristotle still exist only in the soul as concepts (conceptibiliter sunt in anima). What he likely meant was that "good" and "bad" are attributes that "subjectively" presuppose something already constituted in actual being. Berthold perhaps had in mind Nicomachean Ethics I.6, where Aristotle rejected the existence of any ideal Good that would be distinct from its different meanings in the various genera of being; any universal Good apart from these instances could only be an abstraction. Indeed, Berthold immediately cited Eustratius' criticism of this argument as "sophistic", given that Aristotle himself affirmed at the beginning of the Ethics that "the Good is what all things desire". ${ }^{25}$ For Dionysius, as Berthold noted, this universal desire is precisely one of the reasons the Good should be placed beyond the difference of being and non-being, because it extends its causal power to both what is and what is not. ${ }^{26}$

Therefore, according to Berthold, when Proclus stated in Proposition 11 that being is the immediate effect of the first cause, he meant something very different from Aristotle, for Proclus has understood being as being (ens in eo, quod ens) in the "Platonic" way. In Berthold's view, Aristotle worked with two meanings of ens. It either referred to being in its generality, insofar as it abstracts both from motion and change (physical being) and from mathematical being (this is what Aristotle studied in the Metaphysics) or it referred to being as it is constituted from its intrinsic principles, that is, after one has removed the extrinsic principles of efficient and final causality from one's consideration of being (this is what Aristotle studied in Metaphysics XII, where he focused only on the intrinsic principles of matter and form in substance). ${ }^{27}$ The Platonists, however, gave "being as being" three additional senses, each of which referred

23 Berthold of Moosburg, Expositio, 1D, p. 77, 1. 218-19: Ens et unum praedicamenta universalia sunt, quae non habent esse extra animam.

24 Aertsen, Medieval Philosophy as Transcendental Thought, p. 548.

25 Berthold of Moosburg, Expositio, 11A, p. 187, l. 68-80.

26 Berthold of Moosburg, Expositio, 11A, p. 187, l. 81-86.

27 Berthold of Moosburg, Expositio, 11B, p. 188, l. 100-117: [...] Et secundum hanc generaliorem entis rationem Aristoteles prosequitur de ipso in sua Metaphysica. [...] Et istum modum entis ponit Aristoteles XII Metaphysicae, ubi etiam dicit Commentator, quod res habet rationem entis in eo, quod ens, inquantum subsistit ex his intrinsecis suis principiis, scilicet materia et forma. 
to the ordered series of real intentions that are found in the universe. In the broadest sense, it refers to the entire order of being and the higher principles that constitute it (goodness and infinity); more strictly, it refers to the primordial cause of being; finally, most strictly, it refers to anything contained within the order generated by that primordial cause. ${ }^{28}$ According to Berthold, Proposition 11 could be interpreted relative to all three Platonic senses of "being as being", but more properly it should be understood to the final sense. Either way, Proclus was describing being as it really is in the nature of things, where what is more universal in its influence or more indeterminate is prior to what is more determinate or less universal. By indicating a more adequate interpretation of the proposition, in which the phrase "from one first cause" ( $a$ b una prima causa) would refer to the order of beings descending from the primordial cause of being, Berthold was signalling how thoroughly Proclus differed from the later standpoint of the Liber de causis and its unequivocal affirmation that the first of created things is being (Proposition 4: prima rerum creatarum est esse et non est ante ipsum creatum aliud).

For the remainder of the Expositio, whenever Berthold explicitly compared Plato and Aristotle, it was most frequently on the question of abstraction and separation or, in other words, on the logical universality of predication and the theological universality of separation (see, e.g., $16 \mathrm{D}, 67 \mathrm{C}, 135 \mathrm{~K}$, and $136 \mathrm{D}-$ E). Berthold's source for this distinction once again was Dietrich of Freiberg, who maintained that "abstraction is the work of reason" but "separation is the work of nature". ${ }^{29}$ But with Berthold, especially owing to his interpretation of Dionysius' De mystica theologia through Proclus, this distinction took on a soteriological valence entirely absent in Dietrich. As Berthold has presented it, the metaphysics of being is founded on a physicalist approach to the relation of act and potency that ultimately accounts for the origin of diversity through a merely logical reflection: in the physical world, act determines potency; in metaphysics, the most formal intentions and the categories of our understanding are merely notional additions to being. The kinds of plurality we are left with are catalogued only according to the different kinds of predication.

To reason only according to logical universals was, therefore, to remain in the familiar order of what is "according to us". From this point of view, lurking behind the metaphysics of being is the spectre of solipsism. The assumption was never far from Berthold's mind that Proclus and Dionysius were talking

28 Berthold of Moosburg, Expositio, 11B-C, p. 188, l. 118 - p. 189, l. 166.

29 Dietrich of Freiberg, De animatione caeli, 36.1, p. 42, 1. 64-67. 
about the same thing when Proclus subordinated Aristotle to Plato while outlining the hierarchy of modes of cognition in De providentia et fato, and when Dionysius introduced the mode of mystical theology:

Indeed, these cognitive principles relate only to beings, although according to different reasons. However, many divine things are above being. For this reason, in chapter 1 of the Mystical Theology, [Dionysius] calls 'unlearned' those 'who are sealed off in beings and believe that there is nothing supersubstantially beyond beings, but they presume to know, with that cognition that is according to themselves, him, who makes the shadows his hiding place. Consequently, it is impossible that we should receive those things that are above us according to our ownness [iuxta proprietatem nostram ] and thus compare things divine with a reason that has been reared on the senses. ${ }^{30}$

The Platonists attend to the things established in nature (res rata in natura) rather than logical categories (esse in anima). ${ }^{31}$ Their orientation to reality is, in other words, primarily an ecstatic one. The fundamental boundary between doing theology "according to ourselves" and "not according to ourselves" corresponded to the difference between logical and theological universals. To think the immaterial, the categories of thinking that are at home in the physical world must be reversed. But it is important to bear in mind that, for all of this, Berthold did not denigrate the material world or natural philosophy. The invisible things of God are always sought first of all through the creation of the world, whether the world is regarded as an obscure "vestige" of them or a more transparent "sign". It would be better to say that, for Berthold, Aristotle's natural philosophy would in fact be better served by grounding it in the divine science of the Good.

Here Berthold owed something further to Dionysius, and his notion that the divine light or "thearchic ray" reaches the human mind through

30 Berthold of Moosburg, Expositio, Praeamb. C, p. 64, l. 395 - p. 65, l. 421: Verum quia ista principia cognitiva non sunt nisi entium, licet secundum diversas rationes, pleraque autem divinorum sunt superentia [...] unde et in Mystica theologia cap. 1 indoctos vocat, 'qui in existentibus sunt firmati nihil super existentia supersubstantialiter esse opinantes, sed putantes scire ea, quae secundum ipsos, cognitione eum, qui ponit tenebras latibulum suum. Cum ergo hoc sit impossibile, scilicet quod iuxta proprietatem nostram ea, quae sunt super nos, accipiamus et hoc comparantes divina rationi connutritae sensibus. Cf. Expositio, $71 \mathrm{D}$, p. 35, l. 123-127, cited above in Introduction, section 3, n. 15 o.

31 See, for example, Berthold of Moosburg, Expositio, 1A, p. 74, l. 106-109; 11A, p. 186, l. 54-55; 16D, p. 28, l. 143; 51A, p. 113, l. 19; 64D, p. 196, 1. 120. 
the material world precisely to lure it outside itself. When commenting on what Dionysius meant when he says that the divine science proceeds "not according to ourselves", Berthold cited this famous dictum from De caelesti hierarchia:

It is impossible for the thearchic ray to illumine us from above unless it envelops itself, in order to elevate us, with various sacred veils that are according to us [quae sunt secundum nos], arranged naturally and familiarly by the paternal providence. ${ }^{32}$

These veils include the spectacles (theorias) spoken of by two commentators on Dionysius, John the Scot and John the Saracen. These are summoners (appellantes), beckoning to the created intellect through "lights" scattered in creatures in the mode of "vestiges, images, and signs" (as in the oblique and the direct motions) to draw it to God. The final ascent to God, however, as Berthold made clear by turning from this tacit citation of Albert's Summa theologiae to the De mystica theologia itself, is only attained by those who go beyond these veils and theophanies into the divine darkness. ${ }^{33}$ This, for Berthold, is God's way of drawing the soul out of the solipsism to which it so instinctively inclines, and that has expressed itself detrimentally in the metaphysics of being. Berthold's interpretation of Proposition 1 thus was a first and decisive indicator of the path for the desirous soul to follow through the veils.

32 Berthold of Moosburg, Expositio, Prol. 16, p. 25, l. 66o-664: Et notandum, quod [Dionysius] dicit 'non secundum nos' etc. (hoc est inquantum humani), quia 'neque possibile est aliter nobis supersplendere thearchicum radium nisi varietate sanctorum velaminum sursum active circumvelantum et his, quae sunt secundum nos, providentia paterna connaturaliter et familiariter apparantum. Cf. Dionysius, De caelesti hierarchia, 1.2, 121B-C.

33 Berthold of Moosburg, Expositio, Prol. 16, p. 25, 1. 671-674: 'solum non velate et vere apparet' omnia transcendentibus et introeuntibus caliginem. In this respect, Berthold anticipated the interpretation of Dionysius we find in authors like Denys the Carthusian (d. 1471), who criticised earlier commentators, including Aquinas, for holding too narrowly to the principle that God only appears to the created intellect in veils and for passing over precisely these passages from De mystica theologia. See K. Emery, "Sapientissimus Aristoteles and Theologicissimus Dionysius. The Reading of Aristotle and the Understanding of Nature in Denys the Carthusian", in A. Speer, A. Zimmermann (eds), Mensch und Natur im Mittelalter (Berlin: De Gruyter, 1992), p. 572-606, at p. 579-59o; id., "A Complete Reception of the Latin Corpus Dionysiacum. The Commentaries of Denys the Carthusian", T. Boiadjiev, G. Kapriev, A. Speer (eds), Die Dionysius-Rezeption im Mittelalter (Turnhout: Brepols, 200o), p. 197-247, at p. 229-231. 


\section{Creation}

The former [existence] is for the sake of the latter [order], because an isolated essence does not properly have the notion of 'good' unless it is ordered. ${ }^{34}$

Therefore, goodness is the essential mode or intention of any given thing. ${ }^{35}$

Berthold often illustrated the most fundamental principles of Proclus' philosophy using analogies from the physical world. For him it seems that the fundamental metaphysical registers of unity and goodness could each be illustrated through a specific metaphor or image, and each image required the other to be properly understood. In the register of unity, we can see that Berthold preferred the analogies of the containment of all numbers in the monad or of all radii of a circle in its centre. ${ }^{36}$ In the register of goodness, he used the analogy of the spontaneous generative activity of the sun as the clearest example of the self-diffusivity of the Good, in its action that is prior to the finite division of choice and necessity. ${ }^{37}$ One image without the other would give the impression of either stasis (numerical relations without dynamism) or chaos (generative power without order). Therefore, it was fitting that in the commentary on Proposition 30 ("Everything that is produced immediately from another, remains in the producer and proceeds from it"), ${ }^{38}$ which in effect summarised the entire process of procession and return, the two analogies were combined in Berthold's only explicit citation of Eriugena's Homilia on the Prologue

34 Berthold of Moosburg, Expositio, 25H, p. 148, 1. 389-394: Quod omne perfectum citra primum agat per intentionem diffundendi bonitatem suam et sic procedat in generationem secundum ultimum potentiae suae, patet ex eo, quod bonum in recipiente est duplex, scilicet absolutum, quod est esse, et respectivum sive bonum in ordine. Et primum est propter secundum, quia absoluta essentia non habet rationem boni proprie, nisi prout est ordinata.

35 Berthold of Moosburg, Expositio, 7 A, p. 141, l. 96: Bonitas igitur est uniuscuiusque rei essentialis modus sive intentio.

36 Berthold of Moosburg, Expositio, 1F, p. 79, l. 296 - p. 8o, l. 308; 2A, p. 82, l. 34 - p. 83, l. 35; 2C, p. 86, l. 144-145; 3A, p. 92, l. 27 - p. 93, l. 32; 9 E, p. 173, l. 230-232.

37 Berthold of Moosburg, Expositio, ${ }_{5}$ C, p. 119, l. 222-224; 8E, p. 163, l. 224-236; 18A, p. 44, l. 26 29; 18B, p. 47, l. 135 - p. 48, l. 152; 18D, p. 52, l. 297 - p. 53, l. 323; 22A, p. 102, l. 14O-145; 23E, p. 119, l. 250-256; 25 I, p. 149, l. 436 - p. 15o, l. $440 ; 152 \mathrm{C}$, p. 142 , l. 7o. On this conception of freedom in Berthold, as he extracted it and amplified it from Albert the Great and Ulrich of Strassburg, see W. Goris, "Metaphysical Freedom. From Albert the Great to Berthold of Moosburg", forthcoming.

38 Proclus, Elementatio theologica, prop. 30, p. 20, 1. 1-2: Omne quod ab aliquo producitur immediate manet in producente et procedit ab ipso. 
of John (which he attributed to Origen). ${ }^{39}$ When employing either image, Berthold would often introduce it as an "elegant", "careful", or "beautiful" illustration of a metaphysical argument. ${ }^{40} \mathrm{He}$ of course found the comparison of God to the sun in numerous sources including Dionysius, Proclus, Avicebron, Albert the Great, and Ulrich of Strassburg, and although he was not familiar with Plato's famous analogies of the Sun, Line, and Cave in the Republic, he nevertheless recognised the principle that "the Good is diffusive of itself and being" had its origin in Plato, who wrote in the Timaeus that "jealousy is far removed from what is best" (ab optimo porro invidia longe relegata est) - this principle, he maintained, "must be pondered with diligence".41

Berthold also found it necessary to use both images in his commentary to Proposition 125 on the spontaneous causal activity of the gods:

Every god, from wherever it begins to show itself in an order, proceeds through all secondaries, and indeed always multiplies and distributes its outflowings, but always retains the characteristic of its own hypostasis. ${ }^{42}$

Evidently the term that stood out to him here was emicare, "to appear suddenly" or "to break forth", since he devoted the entire discussion of the suppositum (the authoritative, doctrinal background presupposed by Proclus) to "the conditions of light" and how "these are found in the divinising nature". ${ }^{43} \mathrm{He}$ argued that the three conditions of light were described in the analogy of the sun from Dionysius. (1) Light acts through its essence: "our sun does not reason

39 Berthold of Moosburg, Expositio, 3oD, p. 196, 1. 206-215: 'Conspice, quomodo omnium rerum, quas mundi huius sensibilis globositas comprehendit, causae simul et uniformiter in isto sole, qui est maximum mundi luminare, subsistunt, quomodo numerositas herbarum et fructuum in singulis seminibus simul continentur, quomodo multiplices rerum in arte artificis unum sunt et in animo disponentis vivunt, quomodo infinitus linearum numerus in uno puncto unum subsistit! Et huiusmodi naturalia perspice exempla, ex quibus velut physicae theoriae pennis poteris arcana verbi mentis acie inspicere et, quantum datur humanis rationibus, videre, quomodo omnia, quae per verbum facta sunt, in ipso vivunt et facta sunt!' This is a collection of phrases from chapters 9 and 10 of the Homily.

For example, beside the text of Proclus' De decem dubitationibus cited at Expositio, $122 \mathrm{~F}$, p. 119, l. 175-180 in Ms Basel, Universitätsbibliothek, F.IV.31, f. 5orb, Berthold has written puta pulchrum exemplum.

41 Berthold of Moosburg, Expositio, 7A, p. 139, l. 17-23; 13B, p. 212, l. 111-112.

42 Proclus, Elementatio theologica, prop. 125, p. 63, l. 1-4: Omnis deus, a quocumque inceperit ordine emicare se ipsum, procedit per omnia secunda, semper quidem plurificans suas derivationes et partiens, servans autem proprietatem proprie ypostaseos.

Berthold of Moosburg, Expositio, 125, p. 147, l. 11-13. 
or choose" but shines by virtue of its very being. (2) Light shines universally: "it illumines all things capable of participating its lights", each according to their capacity. (3) Light shines unceasingly. ${ }^{44}$

These were not only metaphors for Berthold, who held that there was a deeper continuity between the laws describing the diffusion of physical light and the principles of the diffusion of the highest Good. As he noted here, since every essence flowing into another (influens in aliam) either is light or has the nature of light, and since the Good is self-diffusive, "the Good therefore is light or has the nature or characteristic of light". ${ }^{45}$ We are then given several passages from Dionysius where the Good is likened to the sun, whose causal activity Berthold described as a exseritio, a "revealing" or a "stretching-forth".46 The light of the Good redounds through the primordial causes or gods, the rays of goodness (radii bonitatis), who imitate its causal activity within their own domains.

This account of divine diffusion and manifestation was then balanced in Proposition 125 by a discussion of the gods' remaining. ${ }^{47}$ Here Berthold used metaphors from the Clavis physicae to illustrate his point: the first causes in themselves are one and are not separated from one another, but they are divided in their effects; "just as in the monad all numbers are one [and] simple", so all the primordial causes are one individual in the divine Word. ${ }^{48}$ We should not marvel, the Clavis continued, that this escapes the finest point of our mind (mentis nostrae aciem fugiat) which is already overwhelmed by instances of this in the concentrated and generative power of seeds, which burst forth into variegated forms, colours, and fragrances.

Elsewhere, following the same lead from the Clavis, Berthold extended this principle about the ineffable abundance found among things in his comments to Proposition 121 ("Everything that is divine has an essence that is goodness, a unifical potency, and a cognition hidden and incomprehensible to all

44 Berthold of Moosburg, Expositio, 125A, p. 147, l. 16 - p. 148, l. 31. Cf. Dionysius, De divinis nominibus, 4.1 and 4.4 .

45 Berthold of Moosburg, Expositio, 125B-C, p. 148, l. 33 - p. 149, l. 78.

46 The verbal form of this noun (exsero, exserere) was used in a similar context by Albert the Great. See, for example, Albert the Great, De causis et processu universitatis a prima causa, lib. I, tr. 2, c. 2, p. 27, 1. 22-58. It was taken up by Ulrich of Strassburg, De summo bono. Liber 4, Tractatus 1-2,7, ed. S. Pieperhoff (Hamburg: Meiner, 1987), lib. IV, tr. 1, c. 5 (5), p. 28, l. 42-50.

47 Berthold of Moosburg, Expositio, 125D-F, p. 149, l. 83 - p. 152, l. 176.

48 Berthold of Moosburg, Expositio, 125F, p. 152, l. 164-173, cited Dionysius, De divinis nominibus, 5.6 for the same analogy. 
secondaries altogether"), ${ }^{49}$ to declare that any essence (usia), creaturely or divine, is incomprehensible:

In all things that exist, usia is altogether incomprehensible in itself, not only to sense, but even to intellect. 'For just as God, as he is in himself beyond every creature, is not comprehended by intellect, so likewise the creature in its hidden depths is known to be incomprehensible. Whatever is perceived by bodily sense or considered by intellect in any creature is nothing other than some accident of some incomprehensible essence. What is known through quality, or quantity, or form, or matter, or any accident is not what it is, but that it is'. ${ }^{50}$

Berthold did not explain precisely how he interpreted the Clavis on this point, though a comparison with other passages in the Expositio can offer some further clarification. To be sure, he did not view it within the broadly Aristotelian perspective of the ten categories, even though these were integral to Eriugena's original argument in Periphyseon I and remained central to the Clavis. Rather, it seems likely that Berthold would have understood this assertion within the context of his doctrine of participation, according to which the essences of creatures are constituted by different formal intentions. ${ }^{51}$ Of these intentions, he identified goodness or unity as the deepest or most essential mode. ${ }^{52}$ It is

49 Proclus, Elementatio theologica, prop. 121, p. 6o, 1. 1-3: Omne divinum existentiam [Berthold: essentiam] quidem habet bonitatem, potentiam autem unialem et cognitionem occultam et incomprehensibilem omnibus simul secundis.

50 Berthold of Moosburg, Expositio, 121E, p. 107, l. 68-75, citing Honorius Augustodunensis, Clavis physicae, c. 6, p. 5, l. 12 - p. 6, l. 19: Usia in omnibus, quae sunt, omnino per se ipsam incomprehensibilis est non solum sensu, sed etiam intellectu. 'Quia sicut Deus ultra omnem creaturam in se ipso nullo intellectu comprehenditur, ita etiam in secretis suis creatura incomprehensibilis cognoscitur. Quidquid autem in omni creatura vel sensu corporeo percipitur vel intellectu consideratur, nihil est aliud nisi quoddam accidens unicuique incomprehensibili essentiae, nam aut per qualitatem aut quantitatem aut formam aut materiam vel quodlibet accidens cognoscitur, non quid est, sed quia est'.

51 See the centrality of goodness in the citations of the Clavis at Berthold of Moosburg, Expositio, 2A, p. 82, 1. $12-$ p. 83, 1. 38. The notion that the essence of the first cause is diffused intentionally (intentionaliter) through the universe likely came to Berthold through Dietrich of Freiberg, De cognitione entium separatorum, 79.3, p. 242, 1. 36-46. See 4.5, n. 268, below.

52 Cf. Berthold of Moosburg, Expositio, 3D, p. 97, l. 192-198: ea, quae fiunt unum per creationem, sic fiunt unum, ita, quod ipsum fieri unum est eis esse unum, cum inquantum huiusmodi sint unum tantum, quod est uniuscuiusque eorum essentia; $5_{5}^{\mathrm{B}}$, p. 118, l. 19o-192: licet, ut solum a primo procedunt, stent sub unitate intentionis (scilicet boni), quae etiam est cuiuslibet essentia; 7 A, p. 141, 1. 70-73 and p. 143, 1. 170-171. 
as good or one that a creature is related immediately to the creative activity of God.

To understand this point, we may begin by looking at his comments on Proposition 7 ("All that is productive of another is greater than the nature of that, which is produced"), ${ }^{53}$ which Berthold regarded as "almost the foundation of the whole edifice of this science". ${ }^{54}$ Its proof must establish that what is produced depends on the producer not only for its existence but also for whatever causal power it has. The celebrated maxim of Dionysius, which Berthold traced to the Timaeus, served that purpose well. The Good is not only diffusive of existence (esse) but also itself (sui) - in other words, the Good communicates the very power of self-diffusivity. Explicating the notion of "good" (ratio boni) any further was, however, no straightforward matter. Since it cannot be defined through anything prior to itself, it must be known through its effects or proper modes. ${ }^{55}$ Even the name "the Good" does not capture its quiddity, if it even has one, but rather reflects how we bless (sanctificamus) the origin of all with the noblest name at our disposal. Berthold's description, rather than definition, of the Good was this:

'Good' is the essence of any given thing according to the reason by which it primarily subsists formally from the universally first cause, [subsisting] either as such or according to some determinate mode participated from that, which subsists as such. ${ }^{56}$

Berthold glossed this description extensively. ${ }^{57}$ By "the essence of any given thing", he had in mind the arguments made by Dionysius, that if you remove the good from something, you remove the thing altogether. According to the Areopagite, even privation and non-existence depend upon the Good. In this respect, "good" is the most formal or essential aspect of a thing because all other determinations presuppose it, ${ }^{58}$ just as "being" was regarded as fundamental

53 Proclus, Elementatio theologica, prop. 7, p. 6, 1. 1-2: Omne productivum alterius melius est quam natura eius quod producitur.

54 Berthold of Moosburg, Expositio, 7A, p. 139, l. 9-10.

55 Berthold of Moosburg, Expositio, 7A, p. 140, l. 40 - p. 141, l. 69.

$5^{6}$ Berthold of Moosburg, Expositio, 7A, p. 141, 1. 70-73: bonum est uniuscuiusque rei essentia secundum eam rationem, qua primo formaliter a causa universaliter prima subsistit vel simpliciter vel secundum aliquem determinatum modum participatum ex eo, quod subsistit simpliciter.

57 Berthold of Moosburg, Expositio, 7A, p. 141, l. 74- p. 143, l. 167.

58 A parallel argument at Expositio, 21D, p. 84, 1. 295-312, makes it clear that here he was extending Averroes' critique of Avicenna, who held that a thing is one by an addition to its common nature. "One" and "good", Averroes argued, are not accidental to a thing. 
from the standpoint of the universality of predication. This priority of "good" is not so clear if we take as our starting point a given object of everyday experience, in which the notions of "being", "one", and "good" indeed seem to coincide. But if we consider these notions "absolutely" or in themselves, according to Berthold, then we see that "good", in its orientation to the final cause or end as intended by the principle, can precede the subject in which it inheres. ${ }^{59}$ Berthold at this stage would invoke the creative etymology of bonitas as a derivation from the Greek boo-boas, meaning, "I call out, you call out" (clamoclamas). ${ }^{60}$ The Good calls all things immediately into being. Where there are necessarily lower traces of this causality that are unable to subsist as good simpliciter (as only the gods or primordial causes can), the Good determines or contracts its causal power through these gods or primordial causes, which are nearer to it, in order to strengthen the lower to realise its perfection.

Although we find ourselves at metaphysical bedrock of the Expositio and can only rely on descriptions and metaphors instead of precise definitions, it is important nevertheless to be as clear as possible about what Berthold was aiming for. It was not, as these statements from Dionysius initially could be taken to imply, that the creative activity of the Good was responsible for a thing's potential for existence. According to Berthold, that very potentiality for existence is a function of the subsequent limitation of the causality of the Good through the primordial cause of power (virtus) or infinity (infinitas), which is the principle immediately subordinate to the Good. ${ }^{61}$ Even the orientation toward existence presupposes a more spontaneous creative activity. One way to clarify this difficult notion is to consider that the effect of the primordial cause of power or infinity, for Berthold, is a determinate potentiality for subsistence. What this presupposes is the more holistic causality of the Good, which is perhaps better understood as providing the relational context or the dynamic universal structure within which the essence will exercise its function. ${ }^{62} \mathrm{~A}$ thing exists for the sake of its function, which is its perfection. ${ }^{63}$

59 Berthold of Moosburg, Expositio, 7A, p. 141, l. 97 - p. 142, l. 133.

6o Berthold of Moosburg, Expositio, 7B, p. 146, 1. 276-282. On the use of this etymology in Eriugena, Albert the Great, and Ulrich of Strassburg, see De Libera, Métaphysique et noétique, p. $186-187$.

61 Berthold of Moosburg, Expositio, 3B, p. 94, 1. 77-92. See 4.4, n. 193, below.

62 Berthold of Moosburg, Expositio, 7A, p. 144, l. 181-182: boni determinatio non est aliud nisi boni diversa in diversis participatio.

63 Berthold of Moosburg, Expositio, 13F, p. 218, l. 307-312. Cf. Dietrich of Freiberg, De intellectu et intelligibili, I.1.1, p. 137, 1. 3-6: Sicut dicit Philosophus in II De caelo et mundo, unaquaeque res est propter suam propriam operationem. Cuius dicti ratio est, quia propria operatio est pertinens ad perfectionem rei et habet rationem boni et finis, propter quem res est, sine quo omnis res esset frustra. 
But this perfection is not entirely self-serving. Berthold gave a strong interpretation of Dietrich of Freiberg's declaration that a separated and isolated essence (absoluta essentia) does not have the notion of the good (ratio boni), but only insofar as it is ordered to something outside itself. ${ }^{64}$ In this view, at the level of the singular or the individual, relationality precedes substantiality; the totality is prior, and the parts have their function and possibility only with respect to the whole.

We have seen already how, in Berthold's view, Plato's theorems direct the soul outside itself to the things in nature (res rata in natura) and away from the abstractions that have their reality only in the soul (esse in anima) that the mind exclusively clings to so long as it is "sealed off in beings". The progress of intellectual perfection culminates in the non-discursive and operative union with the One. We glimpse now, in Berthold's commentaries on Propositions 1 and 7 , how the habit of supersapientia is already underway as one sets out along the oblique motion from rational starting points that are oriented toward the One and the Good. That is, the soul's adjustment of its thinking to the realities outside it, even at these initial stages, anticipates that divinising end precisely because it mirrors the most fundamental disposition of the One or Good itself. In Proposition 1, when Berthold first explained the Platonic perspective on the origin of plurality, he stated that it must be sought ultimately with reference to "the disposition of the first cause" that led it to produce. ${ }^{65}$ For this he turned directly to Dionysius: the first cause is drawn out of itself by "the ecstasy of divine love" (exstasis divini amoris), which disposes the cause to communicate not just one but all possible modes of its goodness. ${ }^{66}$ This generative ecstasy at the ground of reality "necessarily" institutes a plurality, because only diverse gradations of unity and goodness are "the perfect demonstration of wisdom". Similarly, in Proposition 7, Berthold argued that his description of goodness as the essential mode of any given thing was compatible with the Platonic understanding of creation as "the immediate procession of plurality from the first cause". 67

64 See Berthold of Moosburg, Expositio, 25H, p. 148, l. 389-394, cited at n. 34, above. Cf. Dietrich of Freiberg, De intellectu et intelligibili, I.10.3, p. 143, 1. 22-38.

65 Berthold of Moosburg, Expositio, 1C, p. 75, 1. 151 - p. 77, 1. 208.

66 Berthold of Moosburg, Expositio, 1 C, p. 76, 1. 197-200: exstasis divini amoris est causa multitudinis rerum creatarum, exstasis, inquam, quae non sinit ipsum esse sine germine, sed disponit ipsum ad communicandum se omnibus modis, quibus est possibile communicare bonitatem suam. This was a tacit citation of Albert the Great, Summa theologiae, ed. A. Borgnet, Opera omnia, vol. 32 (Paris: Vivès, 1895), pars II, tr. 1, q. 3, m. 3, a. 1, p. 25a, which Berthold embellished with Dionysius, De divinis nominibus, 4.13, 712A-B. Berthold of Moosburg, Expositio, 7A, p. 143, l.162-163. 
The Platonic account of creation is discussed at greatest length in Proposition 5 ("Every plurality is set beneath the One"). ${ }^{68}$ Berthold began there by outlining the Peripatetic doctrine of the procession of all things from the One. ${ }^{69}$ His major Peripatetic authority was Avicenna's Liber de philosophia prima sive scientia divina IX.4. Avicenna was frequently cited in seminal works by William of Auvergne and Thomas Aquinas as an example of an erroneous doctrine of mediated creative causality, according to which God creates the highest separate intelligence, which then creates the second separate intelligence, the first heavenly soul, and the first heavenly body, and so on, until we reach the world of generation and corruption. In this view, since a simple one can only produce a simple effect, diversity must arise through the distinct, comparative activities of the first created intellect. Using Ulrich of Strassburg's De summo bono, Berthold explained the logical ordering of these activities as follows. (1) The first created intellect contemplates the completely necessary existence (necesse esse) of God, from whom it proceeds. It then contemplates itself as having come from the necessary existent and thus understands itself as necesse esse, for it beholds itself in the light of God's intellect. In so doing, the intellect constitutes another intellectual substance beneath itself as an intellectual light, which however is diminished because it does not possess the abundance of the first light. (2) The first created intellect then contemplates itself insofar as it is in act, and thus the light of God's intellect falls (occumbit) within it. The intellect then extends its light to another being below it, and thereby constitutes the first heavenly soul and the immediate mover of the outermost sphere. (3) The first created intellect then contemplates itself according to the possibility that exists within it, which it receives from itself and not from the necessary existent. As it thinks itself as possible, it produces the heavenly body of the outermost sphere.

The Platonists, according to Berthold, with Dionysius as their chief representative, would not be satisfied with this account. ${ }^{70}$ Although they hold even more strictly to the unicity of the first principle, which is not only "one per $s e$ " but is "the One as such and absolutely self-identical", they are still able to

68 Proclus, Elementatio theologica, prop. 5, p. 4, l. 1: Omnis multitudo secunda [Berthold: submissa] est ab uno.

69 Berthold of Moosburg, Expositio, 5A, p. 113, 1. 13 - p. 115, l. 70. Berthold's explanations of Avicenna's position resemble passages from Ulrich of Strassburg, De summo bono. Liber 4, Tractatus 2, 8-14, ed. A. Palazzo (Hamburg: Meiner, 2012), lib. IV, tr. 2, c. 9 (1), p. 27, l. 20 p. $28,1.49$.

Berthold of Moosburg, Expositio, 5B, p. 115, l. 72 - p. 118, l. 192. 
maintain that plurality is an immediate effect of the One. Giving a catena of citations from Dionysius on the divine differentiation (discretio), Berthold had to concede that here he was relying principally on texts about God as the Good and not as the One, and he reminded the reader that they will ultimately find that these two designations of the first principle are brought together in Proposition 13. Now, the passages from Dionysius all assert that God remains one while acting within plurality, but they do not explain precisely how this is so. First, then, Berthold decided to confront an objection, which he seems to have invented, that called Dionysius' authority on these matters into question: since Dionysius has spoken as "a theologian", these texts should be reserved for matters pertaining to voluntary providence and God's direct interventions in history. However, the objection continued, following "the theologising philosophers or philosophising theologians", one must hold that in the order of natural providence things proceed from the One in a mediated and linear fashion, just as Avicenna has proposed. Berthold responded that, on this question of the origin of multiplicity from the One, it makes no difference which order of providence was being considered. The Platonists do not even have to abandon the principle that from a simple one only one can come. ${ }^{71}$ The purpose of this objection and response, it seems, was to show that Dionysius, a theologian, argued according to the same necessary and rational assumptions as the theologising philosophers and philosophising theologians. The greatest of the Platonists, therefore, did not abrogate from the laws of natural reason. This also means that the fuller explanation that follows in Berthold of how the divine differentiation (discretio) immediately produces a plurality can be read back into Dionysius' texts. Berthold must show how the One can be an immediate source of plurality without denying the principle that from a simple one only a one can come.

Although he does not use these terms, his response appealed to something like the notion of enfolding and unfolding. ${ }^{72}$ Berthold first established that for the Peripatetics (Aristotle, Avicenna) and the Platonists (Plato, Dionysius, Boethius), God is as an intellective and volitional principle. The "archetypical world" in God is one in form and in reality and, similarly, his will is "one and immutable". According to the Peripatetics, since plurality is completely unlike the simple and immutable principle, what comes immediately from God must be a mediating principle or "singular one" (unum singulare), that is, the first

\footnotetext{
71 Berthold of Moosburg, Expositio, 5B, p. 116, 1. 108-111: ab uno singulariter existenti non debeat procedere nisi unum, et idem eodem modo manens semper natum est facere idem. 
created intellect. ${ }^{73}$ According to the Platonists, Berthold insisted, this conclusion does not follow:

Notwithstanding these doctrines, the position of Platonic philosophy is that, from the One, which is One as such and absolutely, remaining selfidentical in every way, plurality proceeds immediately, in such a way that it operates itself [agens se ipsum] in plurality and thus multiplies, as was put forward earlier by Dionysius. By 'plurality', I mean not only the partial [plurality] of the unities themselves, which is immediately related to the primarily One, but also the total [plurality] of the universe, insofar as the universe subsists in the intention of 'one' and 'good'. This intention in the First as such is not only the exemplary reason but also the efficient and final reason. ${ }^{74}$

The divine wisdom or art, full of "living, unchangeable reasons", is a principle of order. An order is both one and many. A "singular one", therefore, cannot adequately represent the archetypical world. In Albert's Summa theologiae these arguments were meant to establish the agreement between Aristotle (with his metaphor of the general and the army in the Metaphysics XII.10) and Dionysius concerning the procession of creatures. Berthold, however, having framed a debate between the Platonists and Peripatetics, intervened in Albert's text to reinforce the distinction of formal intentions, and emphasised the priority of "good" as the essential mode or intention of any given thing. ${ }^{75}$ Insofar as the universe, or anything in it, subsists in the intention of "one" or "good", it has come immediately from the One, and does so according to an ordered series.

It is here that we observe how the register of unity complements and corrects the one-sidedness of an exclusive focus on the Good. While the Good provides the dynamic and relational context within which an entity will receive

73 Here Berthold was summarising objections to the immediate procession of plurality presented in Albert the Great, Summa theologiae, pars II, tr. 1, q. 3, m. 3, a. 1, p. 23a-b. This was the same article Berthold had used on the exstasis divini amoris.

74 Berthold of Moosburg, Expositio, 5B, p. 116, 1. 130 - p. 117, 1. 137: His autem non obstantibus positio Platonicae philosophiae est, quod ab uno, quod est simpliciter unum et absolute et omnino eodem modo manens, procedit immediate multitudo ita, quod ipsum est agens se ipsum in multitudinem et sic multiplicans, ut supra positum est ex Dionysio; multitudinem, inquam, non solum partialem ipsarum unitatum, quae est immediata ad ipsum prime unum, sed etiam totalem universi, inquantum ipsum universum solum subsistit in intentione unius et boni, quae intentio in simpliciter primo non solum est ratio exemplaris, sed effectiva et finalis.

Berthold of Moosburg, Expositio, 5B, p. 118, l. 19o-192; 5C, p. 119, l. 206-207. 
its possibility and its existence, the essential order of invisible and separate substances must be defined by the structure of number and proportion. This was a principle Berthold accepted from Book II of Aristotle's Metaphysics: "a causal order requires a first, a middle, and a last". ${ }^{76}$ As we saw already in $7 \mathrm{~A}$ and now in ${ }_{5} \mathrm{~B}$, Berthold divided the ordered unities that arise immediately from the One into two groups, in accordance with Proposition 64 ("Every primordial unity establishes a twofold number: some of hypostases that are perfect in themselves; others of illuminations having their hypostasis in others"). ${ }^{77}$ In his commentary on Proposition 64, Berthold began by repeating the contrast between the Aristotelian understanding of unity as a transcendental notion identical with being, which has only esse in anima, and the Platonic view of unity as a res extra animam. ${ }^{78}$ For the Platonists, unity as a principle contains all that comes from itself in potency or virtually (virtualiter). This potency is either (1) active or (2) passive. These in their extreme instances apply to the One and to prime matter, respectively. The active potency is in turn subdivided, such that it can apply (1a) simpliciter to God, ( $1 \mathrm{~b}$ ) to a primordial cause, or (1c) to the trace of the One in any spiritual substance that requires further determination in order to subsist. ${ }^{79}$ This yields the distinction in Proposition 64 between the "the primordial unities" that subsist through themselves ( $1 \mathrm{~b})$ and their "illuminations" that require further determination in order to subsist (1c and 2).

Berthold at this point referred the reader to Proposition 62 ("Every plurality nearer to the One is fewer in quantity, but greater in power, than more remote pluralities" $)^{80}$ for his account of the precise number of the

${ }_{76}$ Berthold of Moosburg, Expositio, 5B, p. 118, l. 178-179; 62B, p. 182, l. 57-61. For a passage known to Berthold that brought together both registers of proportional structure and causal dynamism, see Dietrich of Freiberg, De visione beatifica, prooem. (1-2), p. 13, 1. 2-27.

77 Proclus, Elementatio theologica, prop. 64, p. 34, 1. 1-3: Omnis primordialis unitas duplicem substituit numerum, hunc quidem per se perfectarum ypostaseon, hunc autem illustrationum in aliis ypostasim habentium. In the Tria opuscula, he found this principle applied to the register of unity. See Proclus, De decem dubitationibus circa providentiam, q. 10, §63, p. 102, 1. 3-7: Duplicibus autem unitatibus entibus sive etiam bonitatibus, quas bonum illud produxit ens causa utrorumque et altero modo unum, et hiis quidem autotelon (id est per se perfectis), hiis autem dispersis in participantibus causis.

78 Berthold of Moosburg, Expositio, 64A-B, p. 193, l. 14 - p. 194, l. 54.

79 The trace of the One (1c) should be subdivided again because it must include (1c $\alpha$ ) the separate substances that are mentioned at $64 \mathrm{~F}$ and $(1 \mathrm{c} \beta)$ human souls, which are not discussed there. On the illumination or vestige of the One in the human soul as an active potency, see Berthold of Moosburg, Expositio, 24B, p. 129, l. 162-198, 162B, p. 17, l. 32-58.

8o Proclus, Elementatio theologica, prop. 62, p. 33, l. 1-2: Omnis multitudo propinquius uni ens quantitate quidem est remotioribus minor, virtute autem maior. 
self-subsistent principles ( $1 \mathrm{~b}$ and $1 \mathrm{c} \alpha$ ). Here, he produced what he regarded as a remarkable (miranda) table enumerating the principles populating the essential order of natural providence (from the One down to, and including, heavenly souls). ${ }^{81}$ The smallest possible essential order, he maintained, and therefore the order nearest to the One, is necessarily composed of the numbers 1 (first), 2 (middle), 3 (last). This corresponds to the six formal intentions of the primordial causes of unity, infinity, being, life, intellect, and soul. Berthold then assigned each primordial cause a number from 1 through 6 as its root (radix). For example, the number 6 corresponds to the soul. The soul is comprised of six formal intentions (goodness, infinity, being, life, intellect, soul). This root is then increased by the same proportion found in the highest order -6 (first), 12 (middle), 18 (last) - to reach the sum of 36 . In other words, in the essential order of the cosmos, there must be 36 heavenly souls. So persuaded was Berthold by this deductive reasoning that he used it to resolve an ancient debate about the exact number of heavenly movers: 36 falls almost in the middle of the figures proposed by Eudoxus (26) and Calippus (47)! ${ }^{12}$ As amusing or naive as this approach must seem, we should bear in mind that Berthold was convinced that the ecstasy of divine love has expressed itself in a supremely orderly way, and that only a model like this can explain how a plurality immediately unfolds from the One and how that One enfolds within itself the archetypical world.

In accordance with his views about the knowledge of God attained by the best of the pagan philosophers of antiquity, Berthold's interpretation of Proclus was thoroughly Trinitarian. Berthold held that a Trinitarian theology could and should be extrapolated from the text of the Elementatio theologica, not because this would extrinsically grant it the Christian form its final and perfect truth required, but because its own coherence as a revival of Plato's thought demanded it. For Berthold, the Platonists had harmonised the registers of unity and goodness, of order and fecundity, in a Trinitarian understanding of the first principle.

In one of the longest treatments of Trinitarian theology in the Expositio, Berthold argued that, since generation (the procession of the Son from the

81 Berthold of Moosburg, Expositio, 62B-C, p. 181, l. 20 - p. 184, l. 138.

82 Berthold of Moosburg, Expositio, 203F, p. 195, l. 177-196. 
Father) is "the communication of nature, it most of all befits that, which is most communicable". And since the first Good is most communicable, this is what Dionysius meant when he said that "the ecstasy of the love of the highest Good does not leave it without seed" (sine germine) - for, Berthold explained, "to sprout forth [germinare] is to generate". ${ }^{33}$ The spontaneous communication of the divine nature in the Trinity (bullitio or "boiling") is thus the precondition for God's spontaneous creative activity (ebullitio or "boiling-over"). ${ }^{84}$ Both dynamics are the result of what Berthold, commenting on the same passage from De divinis nominibus 4.10, called the amorous motion (motus amorosus) that moves the Good to communicate itself. ${ }^{85}$ For the principle to communicate itself in an orderly way, it must already be order itself or, in other words, as Berthold wrote in the Prologus, it must be the primarily Beautiful (prime pulchrum). ${ }^{86}$ The Trinity is the Beautiful because it is "the cause of the agreement and lucidity of universes, calling everything to itself, and gathering all in all into the same". ${ }^{87}$ From "this Beautiful there comes to all beings their beauty according to their proper measure; on account of the Beautiful there arise the concords, friendships, and communions of all things". 88 The relational context created by the Good or Beautiful was thus understood by Berthold as the Holy Spirit unfolding the interrelations present implicitly in the archetypical world or divine Word that is coeternal with the Father.

83 Berthold of Moosburg, Expositio, 40C, p. 41, l. 203-207: quia generatio communicatio naturae est, illi maxime conveniet, quod est maxime communicabile; sed prime bonum est maxime communicabile seu communicativum sui; ergo sibi maxime conveniet generatio. Et hoc est quod dicit Dionysius 4 cap. De divinis nominibus, exstasis amoris summi boni non sinit ipsum sine germine esse; germinare autem generare est. Cf. Albert the Great, Summa theologiae, pars I, tr. 7, q. 30, c. 1, p. 227, 1. 21-29.

84 On the theme of ebullitio, see M.R. Pagnoni-Sturlese, "A propos du néoplatonisme d'Albert le Grand. Aventures et mésaventures de quelques textes d'Albert dans le Commentaire sur Proclus de Berthold de Moosburg", in Archives de Philosophie 43(1980), p. 635-654. For Albert see, for example, Albert the Great, De animalibus, lib. xx, tr. 2, c. 1, p. 1306, l. 34- p. 1307, l. 8: Luminosum enim ita ebullit luces quod continue videtur moveri motu ebullitionis si ipsum est fons lucis sicut est sol [...]. Et sic est in fontali universitatis causa, a qua ebullitione procedunt bonitatum ipsius luces et formae quae in rebus distantibus receptae diversum esse accipiunt secundum diversam recipientium potestatum.

85 Berthold of Moosburg, Expositio, 16A, p. 24, 1. 23-25: Haec Dionysius, ubi clare exprimit motum amorosum esse in prime bono, quo se movet in sui multiplicationem et ad intra propriam naturam per emanationem originalem et ad extra per causalem.

86 Berthold of Moosburg, Expositio, Prol. 19, p. 29, l. 781: prime pulchrum, superbenedicta Trinitas.

87 Berthold of Moosburg, Expositio, Prol. 19, p. 29, 1. 778-779: causa consonantiae et claritatis universorum et ad se ipsum omnia vocans et tota in totis congregans ad idem. Berthold of Moosburg, Expositio, Prol. 18, p. 28, 1. 766-769. 
This Trinitarian philosophy of creation was first outlined in Prologus 9 and 11. As Berthold stated there, the world is made by wisdom, who has built its house upon seven pillars (Proverbs 9:1). ${ }^{89}$ Following the Clavis physicae, he explained that the paternal intellect has fashioned or "hewn out" these pillars or primordial causes in the Word, which is the divine art (ars), and these are divided and multiplied by the Holy Spirit in its effects. ${ }^{90}$ As we have seen, Berthold's response to the Peripatetic arguments about the procession of the cosmos from the simple One in ${ }_{5} \mathrm{~B}$ was based on the assumption shared by Platonists and Peripatetics that the first principle acts through intellect and will. In Berthold's view, these immanent operations of knowing and willing could be assimilated to the begetting of the Son and the mutual spiration of the Holy Spirit. ${ }^{91}$ Such a passage from the immanent operations to the distinction of persons in God was not something Thomas Aquinas, or many Dominicans who succeeded him in the 14th century, would accept; but it does find some precedent in the more emanationist Trinitarian theology of the Franciscan school that followed Bonaventure and, interestingly, in the theology of German Dominicans like Ulrich of Strassburg and Hugh Ripelin of Strassburg. ${ }^{92}$

89 Cf. Berthold of Moosburg, Expositio, Prol. 11, p. 18, l. 439 - p. 19, 1. 471. The seven pillars are those mentioned in $62 \mathrm{C}$, along with the lowest primordial cause of nature or body. Presumably, it was not included in 62 because its effects belong to the domain of becoming or generation, and therefore cannot be enumerated according to the patterns of an immutable essential order. At Berthold of Moosburg, Expositio, 101B, p. 211, l. 26-30, Berthold spoke of seven "formal perfections". For other instances, see, e.g., 8D, $23 \mathrm{D}$, 58A, 71D, $99 \mathrm{~B}, 133 \mathrm{E}, 14 \mathrm{OD}, 155 \mathrm{D}$.

90 Berthold of Moosburg, Expositio, Prol. 9, p. 14, l. 300 - p. 15, l. 320; 126B, p. 155, l. 44 - p. 157, 1. 97. Cf. Berthold of Moosburg, Expositio, 40C, p. 41, l. 177-179: Plato ponit in prime bono paternum intellectum formantem ex se verbum, quod est ratio omnium faciendorum, imago, Filius et ars Patris et mundus archetypus, hoc est principalis mundi typus.

91 Berthold of Moosburg, Expositio, 28B, p. 173, l. 77-81; 42F, p. 61, l. 201 - p. 63, l. 279.

92 See R. Friedman, Intellectual Traditions at the Medieval University. The Use of Philosophical Psychology in Trinitarian Theology among the Franciscans and Dominicans 1250-1350, 2 vols (Leiden: Brill, 2013), vol. 1, p. 171. According to the more emanationist approach, which Russell Friedman traces back to Richard of St. Victor, the persons of the Trinity are distinguished according to the ways in which they originate or receive divine being. Chapter 6 of Bonaventure's Itinerarium mentis in Deum can be regarded as a locus classicus for this approach, where Bonaventure read Dionysius through Richard, and used the principle that the Good diffuses itself as a way to establish the threeness of persons that must be conceived simultaneously with the divine unity as Being. Friedman distinguishes between the emanationist model and the more relational approach, which emphasised that the persons are defined by already fully formed relations of filiation and mutual spiration. The relational model, favoured by many Dominicans after Aquinas, therefore posited a sharper divide between the creaturely "psychological" intimations of the Trinity in 
We have seen already that Berthold's inspiration for his account of pagan knowledge of the Trinity came from a Franciscan, Thomas of York (Sapientiale I.6) in Proposition 131A-C ("Every god commences its proper operation from itself"). No less important was Dietrich of Freiberg's thorough integration of Augustine's psychological image of the Trinity into the Peripatetic cosmology of the separate intellects, ${ }^{93}$ which Berthold relied on in $131 \mathrm{D}-\mathrm{F}$. Accentuating Dietrich's argument, Berthold identified the ratio boni as the basis of the active overflow of any intellectual principle, whether in God or in intellects that are active through their essence (intellectus in actu per essentiam). Dietrich had already argued that the spontaneous diffusion or boiling-over (ebullitio) of a cause derives its fecundity from a hidden interior transfusion or boiling (bullitio).${ }^{94}$ In God, this interior transfusion constitutes an "order of nature" of distinct persons. In all essentially active intellectual principles below God (the primordial causes down to the highest portion of the human soul), it results only in a relational distinction within a single supposit. ${ }^{95}$ Thus in a spontaneous and free act of Trinitarian overflow, the One produces within itself simple principles (imagines Trinitatis) that are able to carry on the further work of determining the "ones" or "goods" ("vestiges") it has created. ${ }^{96}$

The continuity in this analogy between the creative and unbounded causality of the One or Good as Trinity and the bounded or determinate causality of the primordial causes was established through Berthold's interpretation of

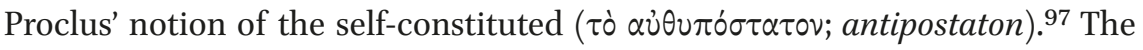
origins of this notion went back at least to Iamblichus (d. c. 325), who used it

the immanent operations of the human soul and its full reality in God, which is known only by revelation.

A. Colli, Tracce agostiniane nell'opera di Teodorico di Freiberg (Genoa: Marietti, 2010). Berthold of Moosburg, Expositio, 125D, p. 149, 1. 83-91.

95 Berthold of Moosburg, Expositio, 131E, p. 196, l. 176 - p. 197, l. 198.

96 On the gods as images of God, see Berthold of Moosburg, Expositio, $3_{2}$ E, p. 210, l. 156-158 and p. 211, l. 183 - p. 212, l. 201; 28C, p. 175, l. 150-151; 177E, p. 178, l. 165-169. Berthold's source was Dietrich of Freiberg, De visione beatifica, 1.2.1.1.6-7, p. 41, l. 2 - p. 44, 1. 46. See also the studies by K. Flasch, "Procedere ut imago. Das Hervorgehen des Intellekts aus seinem göttlichen Grund bei Meister Dietrich, Meister Eckhart und Berthold von Moosburg”, in K. Ruh (ed.), Abendländische Mystik im Mittelalter. Symposion Kloster Engelberg 1984 (Stuttgart: Metzler, 1986), p. 125-134; id., "Converti ut imago - Rückkehr als Bild. Eine Studie zur Theorie des Intellekts bei Dietrich von Freiberg und Meister Eckhart”, in Freiburger Zeitschrift für Philosophie und Theologie 45(1998), p. 130-150.

97 Onself-constitution in Proclus, see S. Gersh, From Iamblichus to Eriugena. AnInvestigation of the Prehistory and Evolution of the Pseudo-Dionysian Tradition (Leiden: Brill, 1978), p. 125-137; C. Steel, "Proklos über Selbstreflexion und Selbstbegründung", in M. Perkams, R.M. Piccione (eds), Proklos. Methode, Seelenlehre, Metaphysik (Leiden: Brill, 20o6), p. 230-255; D.G. MacIsaac, "The Origin of Determination in the Neoplatonism of Proclus", in M. Treschow, W. Otten, W. Hannam (eds), Divine Creation in Ancient, 
to account for the freedom of the rational soul. ${ }^{98}$ Proclus generalised the idea of self-constitution by relating it to substantial self-reversion (Propositions 42 and 43), which enabled him to apply it to almost all immaterial realities. In Proposition 40 ("Everything that proceeds from itself has a self-constituted essence and precedes those things that subsist from other causes"), ${ }^{99}$ the first passage in the Elementatio theologica devoted to the subject, Proclus connected the notions of self-sufficiency and self-constitution, and definitively located both in principles beneath the Good, since its simplicity is beyond self-sufficiency. ${ }^{100}$

For Berthold, however, although the Good is above self-sufficiency because of its superabundant power, it is not above self-reversion or self-constitution. ${ }^{101}$ On the contrary, according to Berthold's interpretation of Proclus in the context of Dietrich's metaphysics, the Good is superabundant or "boils over" precisely because of its self-reversion or interior transfusion (bullitio), which is also true of the gods proportionately in their own domains. When Berthold finally confronted Proclus' refusal of self-reversion in the One in the proof of Proposition 40, he did so carefully:

This [refusal] was disproved above in the declaration, unless perhaps the author wishes to say that, just as the primarily Good is better than selfsufficient principles, namely the antarkes, so also it is better than the per se subsistent, namely, the antipostaton. ${ }^{102}$

Medieval, and Early Modern Thought. Essays Presented to the Rev'd Dr Robert D. Crouse (Leiden: Brill, 2007), p. 141-172, at p. 157-166; E. Ludueña, La recepción de Eriúgena, p. $15^{\circ}-154$.

98 Henry of Ghent used the theorems of the Elementatio on self-reversion for the same purpose. See P. Porro, "The University of Paris in the Thirteenth Century. Proclus and the Liber de causis", in S. Gersh (ed.), Interpreting Proclus. From Antiquity to the Renaissance (Cambridge: Cambridge University Press, 2014), p. 264-298, at p. 269-275.

99 Proclus, Elementatio theologica, prop. 40, p. 24, 1. 1-2: Omnia que ab alia causa procedunt precedent que a se ipsis subsistunt et habentia essentia authypostaton.

100 Proclus, Elementatio theologica, prop. 40, p. 24, l. 17-18: Si autem bonum authypostatum, ipsum se ipsum producens non unum erit. There was a lacuna Moerbeke's translation after this line that omitted Proclus' brief explanation of his assertion: what proceeds from the One is not one; but if the One were self-constituted it would proceed from itself; therefore, the One would be both one and not one.

101 Berthold of Moosburg, Expositio, 1oF, p. 183, l. 229 - p. 184, l. 255. Cf. 9B, p. 169, l. 102-105.

102 Berthold of Moosburg, Expositio, 40 commentum, p. 45, l. 341-344: Istud est reprobatum supra in declaratione, nisi forte auctor velit dicere, quod, sicut prime bonum est melius sibi sufficentibus, scilicet antarkes, ita etiam sit melius per se subsistentibus, scilicet antipostaton. 
In other words, if Proclus only meant that the Good is above the self-sufficient goods or primordial causes (the antarkia described in Proposition 9) and in this sense is above "self-constituted principles", then this more qualified statement is correct. Now, although Proclus posited a kind of self-sufficiency among the gods in texts unknown to Berthold (e.g., Platonic Theology I.19), modern interpreters of Proclus doubt whether self-constitution would apply at that level, given the doctrine's intrinsic relation to self-reversion. ${ }^{103}$ So committed was Berthold, however, to Dietrich's Augustinian and Peripatetic metaphysics that it was unthinkable that self-reversion would not be at the root of all fecundity in the cosmos.

The Elementatio theologica provided several opportunities to address the theme of self-reversion (Propositions 15-17, 42-44, 82-83). Beginning his commentary on $15 \mathrm{~A}$, Berthold invoked Dietrich's conception of the intrinsic formal unity of the cosmos, which consists in "the redounding of one part into another", and in whose dynamism each part acquires the ratio boni. ${ }^{104}$ It is necessary to posit "essential relations" inherent in the nature of each part of this essential order, which preserve this dynamic hierarchy without compromising the simplicity of the parts. ${ }^{105}$ The essences that comprise such an order are completely identical with their operation. ${ }^{106}$ In other words, these essences are inconceivable apart from their intrinsic relation to the rest of the order; ${ }^{107}$ their operation of self-reversion is simultaneously the return to their principle and is nothing else but the outward expression of the first principle within the cosmos. ${ }^{108}$

This basic background helps us to understand Berthold's strategy for navigating Proposition 40. In 40A, he first described two kinds of procession that correspond to the general division of all things into the absolute and the relational (respectivum). ${ }^{109}$ These correspond to the "causal" (absolute) and "original"

103 See MacIsaac, "The Origin of Determination", p. 157-159, and the literature cited there.

104 Berthold of Moosburg, Expositio, 15A, p. 15, l. 12-24. Cf. 6C, p. 13o, l. 103-126.

105 Berthold of Moosburg, Expositio, 15A, p. 15, l. 39-46. Cf. 16A, p. 24, l. 14-31.

106 Berthold of Moosburg, Expositio, 15B, p. 17, l. 102-103.

107 Berthold of Moosburg, Expositio, 32B, p. 207, l. 52-57.

108 Berthold of Moosburg, Expositio, 15C, p. 18, l. 134 - p. 19, l. 139: Potest [se ipsum conversivum ] tamen habere partes ante totum, quae non ponunt in numerum, et sic motu amoroso, qui est virtus concretiva seu unitiva naturalis, festinat ad se ipsum ut ad principium formale suae propriae subsistentiae, et sic continet et figit se ipsum in esse transfundens se ipsum in se ipso se ipsum in alio esse respectivo generando.

109 Berthold of Moosburg, Expositio, 40A, p. 36, l. 11-14. The relational (respectivum) is a more general term than the relative (relativum), since the latter is confined to the category of relation, whereas the former is found in things outside that category. By this Berthold seems to mean that an essence can be intrinsically defined by its tendency (habitudo) toward something. See Expositio, 15A, p. 15, l. 31 - p. 16, l. 38. 
(relational) orders described in 21A-B and 29A. ${ }^{110} \mathrm{~A}$ causal order proceeds to the outside (ad extra) and into a multiplicity of absolutely ordered, distinct natures, whereas the Trinitarian, originative "order of nature" proceeds to the inside (ad intra) and does not result in any inequality of natures. Following Dietrich's interpretation of Augustine, Berthold maintained that this originative order is also found in intellectual creatures as images of God, where it results not in a distinction of persons but in three relationals (tria respectiva) within a single supposit."11 Berthold underscored that this original "order of nature" in God and in the images of God does not multiply their essences. ${ }^{12}$

In $4 \mathrm{OB}$, Berthold then provided definitions of generation and spiration as "emanations" that are general enough to apply to the Trinity or to its images in subordinate principles. ${ }^{113}$ From this general perspective, Berthold then moved to consider the specific differences in the proportion by rehearsing the grades of self-sufficiency he had outlined first in Proposition 9. ${ }^{114}$ The self-sufficient is defined as "that which has from itself and in itself the fullness of its proper goodness" as a formal cause. In this sense, God, and the gods in a secondary way, subsist by themselves whole and wholly (subsistunt se totis et totaliter), meaning that both are constituted only by one formal intention: "one" or

110 Berthold of Moosburg, Expositio, 21B, p. 78, 1. 84-99; 29A, p. 182, l. 12 - p. 184, l. 76.

111 Berthold of Moosburg, Expositio, 21A-B, p. 77, l. 40-41, p. 78, l. 89-9o, and p. 79, l. 122-124.

112 Berthold of Moosburg, Expositio, 40A, p. 37, l. 43-53. In 21B, Berthold gave a fuller account of what he meant by "order of nature" by relying on Albert the Great, Summa theologiae, pars I, tr. 9, q. 41, c. 2, a. 1, p. 317, 1. 87-97. In the background of Albert's text was Dionysius' statement (De divinis nominibus, $2.7,645^{\mathrm{B}}$ ), that the Father, Son, and Holy Spirit are "sproutings of the divine nature" (pullulationes divinae naturae). Here, Albert argued, "nature" must not be understood in the primary sense to mean "essence", because then Dionysius would have asserted that the divine essence is multiple. "Nature" must rather be understood in a secondary sense, as defined by Aristotle: "the power, from which the coming-forth comes forth" (vis, ex qua pullulat pullulans). In this sense, in the Trinity, "nature" stands for "person" (supponit pro persona) with the added connotation of a specific notion of coming-forth (consignificando notionem determinantem modum pullulationis), by which that nature is communicated from one person to another (e.g., paternity, generation, or spiration). In the self-constituted principles below the Trinity, Berthold added, "nature" stands for the relational (pro respectivo) and not for "person", but with the same added connotation of a specific notion of coming-forth.

113 Berthold of Moosburg, Expositio, 40B, p. 37, l. 57 - p. 39, l. 125; 42F, p. 61, l. 201-296. Berthold's sources here are not indicated in the apparatus fontium. His general definitions are taken from Dietrich of Freiberg, De visione beatifica, 1.3.2, p. 53, l. 2 - p. 56, l. 86. From John of Damascus, through Ulrich of Strassburg, Berthold also took a less general definition of generatio that clearly sets it apart from the mutable and temporal kind of generation found among creatures. See Ulrich of Strassburg, De summo bono. Liber 3, Tractatus 1-3, ed. S. Tuzzo (Hamburg: Meiner, 2004), lib. III, tr. 1, c. 2 (3), p. 10, l. 50 - p. 12, l. 103.

114 Berthold of Moosburg, Expositio, 9B, p. 17o, l.124 - p. 171, l. 147; 4OC, p. 39, l. 127 - p. 4O, l. 161. 
"good". The gods are only "formally" self-subsistent since they receive their unity or goodness from the One, and therefore depend on the One as their efficient cause. Here Berthold would look to Proposition 65 to say that the One subsists as "one" according to cause, and the gods subsist as "ones" according to "essence". In this sense, the gods are self-sufficient "not absolutely, but relatively".15 Invoking Proposition 64, Berthold described the gods as supremely self-sufficient as wholes and wholly (secundum se totum et totaliter) by virtue of their simplicity and their superabundant power to originate their unique formal determinations. In other words, as "essential" goods or ones the gods are "wholly" self-sufficient as formal causes, which allows them to act as prisms refracting the causality of the Good into their own orders. Next come entities constituted from at least two principles, which are self-sufficient "as a whole but not wholly": they are self-sufficient as wholes (sufficiunt sibi se totis per se) because they are essentially and always active, but since they are constituted out of more than one formal intention, they cannot be called "one" or "good" in every way (totaliter). Such entities are also known as beings existing as a species (entia secundum speciem). They are composite but not in such a way that they could be called "individuals"; their composition comes only from their essential or formal parts. These comprise the greater population of the invisible world below the gods in Berthold's Platonism: infinities, true beings, lives, and intellectual hypostases. Next, heavenly souls are independent or selfsufficient by their divine and intellectual operation, but their animating (animealis) operation is fulfilled only in a body. Rational or human souls, finally, have self-sufficiency only in virtue of their supreme part that is not conjoined to the body. ${ }^{116}$ This catalogue of self-sufficient principles may be summarised as follows:

115 Berthold of Moosburg, Expositio, 9B, p. 170, l. 108-112; 40C, p. 39, l. 132-137. For this crucial distinction between the primordial causes as subordinated to God (qua efficient cause) and as per se subsistent (qua formal causes), Berthold may have been inspired by Thomas Aquinas' commentary on the Liber de causis. See E. Ludueña, "The Gods and Causality".

116 In Berthold of Moosburg, Expositio, 43A, p. 66, 1. 21 - p. 67, l. 42, Berthold extended the self-constituted or self-conversive all the way from the One and to the possible intellect which, considered as a conceptional being (ens conceptionale) - that is, according to the mode of being that embraces the subject, object, and mode of its knowledge in act - exercises its independence by constituting the quiddities of things. What all these principles share is that they are, at least in their activity, independent (per se standi). On the possible intellect as ens conceptionale, see Dietrich of Freiberg, De intellectu et intelligibili, III.8.19, p. 183, l. 3 - p. 184, l. 51, and B. Mojsisch, "Sein als Bewußt-Sein. Die Bedeutung des ens conceptionale bei Dietrich von Freiberg", in K. Flasch (ed.), Von Meister Dietrich zu Meister Eckhart (Hamburg: Meiner, 1984), p. 95-105. The possible intellect, however, is not (as 
God: per se subsistens absolute

Gods: sufficiunt sibi/subsistunt et secundum se totas et totaliter

Entia secundum speciem: sufficiunt sibi/subsistunt secundum se totas sed non totaliter

Heavenly and human souls: sufficiunt sibi/subsistunt non se totis

Having recalled this order of principles, Berthold then proceeded to outline their dynamic interrelation in his comments on Proposition 40. He appealed to Augustine's acknowledgement that the Platonic doctrine of the divine "art" or "archetypical world" was equivalent to the Christian understanding of the coeternal and only-begotten Word. ${ }^{117}$ Following Dietrich of Freiberg, Berthold pushed this agreement to the limit by extending the Platonic doctrine of the divine art to principles beneath God. ${ }^{118}$ Finally, he went beyond even the letter of Dietrich's text toward a more complete account of the Trinitarian activity of these principles by identifying the role of the spirit (spiritu producentis vehente) in the conveyance of the form within the principle into its effect. ${ }^{119}$ Using a remarkable and singular epithet in the entire Expositio, Berthold then introduced two passages from Dionysius the Platonist (Dionysius Platonicus). One was the familiar passage we have seen several times already describing the Trinitarian emanations as "sproutings of the divine nature". The second follows it in the De divinis nominibus:

Every divine paternity and filiation is given to us and to the supercelestial powers from the primary paternity and primary filiation separated from all things. From these the supercelestial powers become gods, and the sons of gods, and deiform fathers, and are named minds, being perfected

ens naturae) an image of the Trinity because it is not essentially active. See Dietrich of Freiberg, De visione beatifica, 1.2.2, p. 46, 1. 3 - p. 53, l. 41.

117 Cf. Berthold of Moosburg, Expositio, 131B, p. 191, 1. 46 - p. 194, l. 117.

118 Cf. Dietrich of Freiberg, De intellectu et intelligibili, I.8.1-3, p. 141, l. 46 - p. 142, l. 74.

119 Berthold of Moosburg, Expositio, 40C, p. 41, l. 193-194. The phrase spiritu vehente was likely taken from Ulrich of Strassburg, De summo bono, lib. IV, tr. 1, c. 5 (6), p. 29, l. 64-82, where Ulrich rejected the view of certain philosophers, like Hermes, who posited an intermediary spirit bearing the forms of the fluxus from the source to its recipients. Cf. Albert the Great, De causis et processu universitatis a prima causa, lib. I, tr. 4, c. 1-2, p. 44, 1. 5 o and 57, and p. 44, l. 33. Ulrich criticised Arius for identifying this intermediary with the Holy Spirit and argued that the role of such a spiritus should be restricted to corporeal forms. For Berthold, on the contrary, following Thomas of York, the Hermetic spiritus was among the several acceptable witnesses to the pagan knowledge of the Holy Spirit. See Berthold of Moosburg, Expositio, 6E, p. 132, l. 202 - p. 133, l. 208, and 131B, p. 193, l. 81 - p. 194, l. 117, citing Sapientiale, lib. I, c. 14 and lib. viı, c. 6. 
spiritually (that is, incorporeally, immaterially, and intelligibly) by this paternity and filiation. ${ }^{120}$

As Berthold presented it, then, Augustine and Dionysius Platonicus authorised this extension of Trinitarian theology to subordinate principles and "gods". His singular use of the epithet Dionysius Platonicus in the entire Expositio displays the deeper assumptions that were at work here, which can be detected elsewhere in the commentary where we find these Trinitarian passages in the Areopagite cited almost in the same breath as phrases from the Hermetic Liber XXIV philosophorum. ${ }^{121}$ There was no opposition here between pagan and Christian Platonists on the question of first principles; in other words, for Berthold the Platonists held to a Trinitarian account of the divine as Platonists and only incidentally, in certain cases, as Christians.

This Platonism that Berthold held to be so profoundly in accordance with Christian doctrine evidently marked a significant departure from Proclus. Berthold, however, proceeded as if his interpretation conformed to the original Platonic doctrine. This is clearest when Berthold, perhaps anticipating Proclus' refusal of self-reversion in the One, presented an anonymous objection: "if the Good is itself producing itself", that is, if it is self-constituted, "it is not One".122 Berthold's response was a brief and standard assertion of Trinitarian divine simplicity - relations do not multiply the divine essence - with little further explanation. More interestingly, he followed this with what he seems to regard as an undesirable consequence of that argument, which even the objector

120 Berthold of Moosburg, Expositio, 40C, p. 42, l. 214-223: Omnis paternitas divina et filiatio data est et nobis et supercaelestibus virtutibus ex patriarchia ab omnibus segregata et filiarchia: ex qua, et di et deorum filii, patres et deiformes fiunt, et nominantur mentes, spiritualiter videlicet tali paternitate et filiatione perfecta, hoc est incorporaliter, immaterialiter, intelligibiliter [...]. Cf. Dionysius, De divinis nominibus, $2.8,645 \mathrm{C}$.

121 Berthold of Moosburg, Expositio, 40C, p. 42, l. 214-227: Hoc expresse vult Dionysius Platonicus 2 cap. De divinis nominibus, ubi dicit: 'Pater quidem est fontana deitatis [...].' Hermes etiam Trismegistus in prima regula theologica idem videtur intendere [...]. Cf. Expositio, 21F, p. 86, 1. 374-381: Ex praedictis verbis Dionysii manifestum est in thearchica processione divinarum personarum ordinem naturae sive naturalis originis incipere sive principiari, si ita licet dicere, in superaeterna emanatione a Patre, qui est fons supersubstantialis deitatis sive fontana deitas, qui etiam secundum Trismegistum et Alanum dicitur unitas in eo, quod Pater est principium, non de principio. Et sic 'unitas (scilicet Pater) gignit monadem (id est Filium, qui est principium de principio) et in se suum reflectit ardorem (scilicet Spiritum sanctum, qui est amor et nexus Patris et Filii).' Dionysius is also cited alongside the Hermetic Liber in Berthold of Moosburg, Expositio, 64C, p. 194, 1. 56-59; 137A, p. 15, l. 24 - p. 16, l. 36; and 141D, p. 48, l. 122 - p. 49, l. 143 .

122 Berthold of Moosburg, Expositio, 4oC, p. 42, l. 235-236: Nec valet instantia, qua posset dici, quod bonum, si est ipsum se ipsum producens, non est unum. 
would want to avoid: if respective distinction removes unity in the Good, so must it also compromise the unity of the gods. ${ }^{123}$ Perhaps his imagined interlocutor was an interpreter of Proclus who, like Dietrich of Freiberg, had identified the gods with the separate intellects. ${ }^{124}$ Such an interpreter would indeed be unwilling to compromise the real simplicity of the separate intellects (even though they are constituted out of multiple formal intentions), for this would undermine the identity of their essence with their operation. Berthold and anonymous objector shared the assumption that the gods and/or the separate intellects are simple and self-reflexive. Both sides of the dispute would agree that self-reflexivity is so intimately related to the fecundity of the separate principles that the objection must be ruled out.

Once it is granted that God and the primordial causes can be triune and yet simple, Berthold considered another objection arguing that, since he has affirmed a respective distinction in the gods but a distinction of persons in the Trinity, he has effectively made the gods simpler than the Trinity. ${ }^{125}$ This led Berthold to posit a basic but nevertheless crucial explanation of the difference between God and the gods that undergirds the entire metaphysics of first principles in the Expositio. He replied by pointing out that this respective distinction in the gods is in fact a sign of each their limitation: each god has a nature that is "supposited" (suppositata) because it depends on the Good as an efficient cause, and thus receives from outside itself its causal power to produce. It is in this sense, at the conclusion of $4 \mathrm{oF}$, that he will argue that the notion of the self-constituted "primarily" pertains to the self-sufficient gods, which are self-sufficient and limited as "good" but superabundant in their unique formal intentions, and not to God himself who is the superabundant Good. ${ }^{126}$ This was the basis for Berthold's attempt in the commentum to offer an acceptable interpretation of the letter of Proposition 40 in the face of Proclus' outright denial of self-constitution to the One. ${ }^{127}$

\footnotetext{
123 Berthold of Moosburg, Expositio, 40C, p. 42, 1. 237-239: Et praeterea, si distinctio respectiva adimeret unum in prime bono, ergo et in bonitatibus, quarum quaelibet est unum et bonum per essentiam secundum auctorem.

124 See n. 170-172, below.

125 Berthold of Moosburg, Expositio, 4oC, p. 42, l. 239 - p. 43, l. 251. Cf. Expositio, 28B, p. 175, 1. 136-138: In prima [Trinitas], natura est ratio producendi, sed ipsum respectivum est producens; in secunda productione natura absoluta suppositata est producens, sed bonum est ratio producendi.

126 Berthold of Moosburg, Expositio, 4oF, p. 44, l. 283-288.

127 Berthold incorrectly attributed to Proclus the notion that the archetypes exist in the mind of the Good. See Berthold of Moosburg, Expositio, 164D, p. 32, l. 58-9: Huic etiam alludit illud auctoris libro De malorum subsistentia cap. 15, ubi dicit 'apud conditorem universi
} 
As much as Berthold relied on Thomas of York, Dietrich of Freiberg, and his Hermetic sources for his understanding of Platonic Trinitarian theology, he was equally indebted to his Eriugenian sources like the Clavis physicae, the glosses on Dionysius that he attributed to Maximus, the Liber de causis primis et secundis, and the Homilia on John's Prologue for his explanation of how the gods arose within the Word and in what sense they are subordinate to the One. The doxographical outlook of the Expositio was thoroughly informed by Berthold's assumption that the author of the Clavis, supposedly Theodorus the abbot of Constantinople, was heir to a tradition of Dionysian theology that included commentators like Maximus, who transmitted teachings handed down from the Apostles. ${ }^{128}$ This tradition, in Berthold's view, had reconciled the divine names of Dionysius with Augustine's doctrine of the divine ideas. ${ }^{129}$ With this pedigree, Eriugena's synthesis of the Greek Fathers with Augustine in his doctrine of the primordial causes, which both remain within and proceed from the Word, became the Platonism that would unite Dionysius, Augustine, Proclus, and Boethius in Berthold's Expositio. ${ }^{130}$

esse omnes species et specierum numerum. For Proclus, the conditor is the Demiurge, who belongs to the lowest triad of intellectual gods.

128 Honorius Augustodunensis, Clavis physicae, c. 69, p. 48, 1. 4-5: Maximus philosophus tradit a successoribus apostolorum omnium que sunt quinquepertitam divisionem [...].

129 E.g., John Scotus Eriugena, Periphyseon, ed. É. Jeauneau (Turnhout: Brepols, 1996-2002), lib. II, 616C, p. 125, l. 3168-3191: Sunt igitur primordiales causae, quas rerum omnium principia diuini sapientes appellant, per se ipsam bonitas, per se ipsam essentia, per se ipsam uita [...]. Sed ne quis aestimet quae de primordialibus causis diximus nullius auctoritatis munimine fulciri, quaedam ex libro sancti patris Dionysii De diuinis nominibus huic operi inserere non incongruum duximus. Cf. Gersh, "The Content and Method of Platonic Philosophy", p. 497: "Clearly Berthold could not have worked out so successfully the rapprochement between Proclean noetic principles, Pseudo-Dionysian divine attributes, and Augustinian eternal reasons without recourse to the Eriugenian doctrine of primordial causes and their effects". That Eriugenism was so instrumental in bridging the Platonisms of Dionysius and Proclus confirms the verdict of J. Trouillard, "Érigène et la théophanie créatrice", in J.J. O'Meara, L. Bieler (eds), The Mind of Eriugena (Dublin: Irish University Press for the Royal Irish Academy, 1973), p. 98-113, at p. 98: "Quand on a le bonheur de lire Jean Scot Érigène, on est surpris de découvrir [...] une telle puissance de pensée et d'expression. Celle-ci lui de réinventer, à travers des documents mineurs, plusieurs des intuitions les plus originales du néoplatonisme".

130 Berthold of Moosburg, Expositio, 176C, p. 163, l. 206 - p. 164, l. 213: Verum ut ista diversitas [specierum] excludatur, sciendum, quod principale exemplar simplex est intra omnium causam, scilicet prime Deum sive eius mentem secundum Dionysium, Augustinum, Boethium et Platonem cum suis sequacibus, ut iam diffuse ostensum est, exemplaria vero sub primo principali exemplari, quae et ipsa dicuntur et sunt causae primordiales rerum sicut ipsi dii, non quod prime Deus ad extra respiciat in universum producendo, sed quia in eis et per ea determinat suam causalitatem utens eis quasi pro instrumento operationis suae. 
When Berthold read William of Moerbeke's translation of the Elementatio theologica, he found a text inherently amenable to this doctrine of the primordial causes. Moerbeke used the adjective primordialis eight times to translate

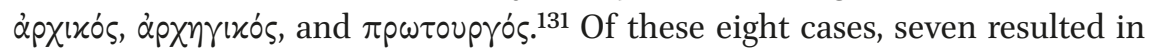
the syntagm primordialis causa or primordialis unitas. Berthold was attentive to these occurrences and sometimes cross-referenced the relevant propositions, ${ }^{132}$ and used Eriugenian sources for four of them (Propositions 64, 97, 121, and 125). In seven of the eight propositions, Dionysius also featured prominently in Berthold's comments, even though the terms primordialis causa and primordialis unitas were completely absent from the Corpus Dionysiacum..$^{133}$ As Robert Crouse has shown, this terminology in Eriugena derived from Augustine's De Genesi ad litteram (lib. vI, c. 10, §17) and from Bede's De natura rerum. ${ }^{134}$ Augustine was likely the source for the syntagm primordialis causa in Hugh of St. Victor, ${ }^{135}$ Peter Abelard, and Peter Lombard's Sentences (lib. II, d. 18, c. 5), and, through them, in the works of Alexander of Hales, Albert the

131 Propositions 64, 70, 71, 97, 113 comm., 115 comm., 121 comm., 125 comm.

132 For example, Expositio, $70 \mathrm{D}$ and $113 \mathrm{~F}$.

133 In certain editions of the Corpus, these terms would have appeared through Thomas Gallus' Extractio, in Dionysiaca, ed. P. Chevallier, 2 vols (Brugge: Desclée de Brouwer, 19371950), vol. 1, In De divinis nominibus, c. 5, p. 693, l. 340-1: Et quod de his dixi, de aliis ideis sive archetypis (scilicet aeternis rationibus Verbi) sentiendum est:verbi gratia, per se bonitas, per se veritas, per se aeternitas, per se ipsa virtus, et similia quae simpliciter et aeternaliter consistunt in Verbo Dei et primordialiter causant omnia existentia. Inter antiquas autem causas primordialior est ipsum esse per se. [...] Et invenies ipsas participationes primordialius fundari in ipso esse. Cf. Thomas Gallus, Explanatio in libros Dionysii, ed. D. Lawell (Turnhout: Brepols, 2011), p. 152, 1. 953 - p. 153, 1. 960: ET VT NOSTRIs. Quia primordiales causalitates mentes nostras excedunt nec sufficimus effectus creatos ad illarum causarum infinalitatem digne conferre [...]; p. 462, 1. 115-126: quia in Verbo Dei summe simplici continentur unitiue et simpliciter omnia exemplaria, et ita omnia exemplarium causata in eodem Verbo uniuntur [...]. ET illud VNVM, id est eterni Verbi unitas, EST ELEMENTATIVVM, id est primordialiter causatiuum, OMNIVM.

134 R. Crouse, "Primordiales Causae in Eriugena's Interpretation of Genesis. Sources and Significance", in G. Van Riel, C. Steel, J. McEvoy (eds), Iohannes Scottus Eriugena. The Bible and Hermeneutics. Proceedings of the Ninth International Colloquium of the Society for the Promotion of Eriugenian Studies Held at Leuven and Louvain-la-Neuve June 7-10, 1995 (Leuven: Leuven University Press, 1996), p. 209-220.

135 See Hugh of St. Victor, De sacramentis Christiane fidei, ed. R. Berndt (Münster i.W.: Aschendorff, 2008), lib. I, pars 2, c. 1-3, 205B-207D, p. 59, l. 2 - p. 62, l. 7, and Hugh's earlier Sententiae de divinitate, translated in B.T. Coolman, D. Coulter (eds), Trinity and Creation. A Selection of Works of Hugh, Richard, and Adam of St Victor (Turnhout: Brepols, 2010), p. 140-154. These texts are quite suggestive of an Eriugenian influence, and even criticise "some" who (wrongly interpreting Eriugena) would see the primordial causes as eternal creatures located between God and the rest of creation (Sententiae, p. 141). 
Great, Bonaventure, and Thomas Aquinas. After Eriugena and Thomas Gallus, Albert, Aquinas, and Ulrich of Strassburg were among the few later authors to employ the terms explicitly in their treatments of Dionysius. ${ }^{136}$ With Berthold, this Eriugenian synthesis of Augustine and Dionysius reached a new degree of fruition.

Prologus 3-5 set the tone for every subsequent discussion of the primordial causes in the Expositio. In these passages, Berthold first introduced his readers to the notion of primordial causes and went to great lengths to demonstrate how this terminology was faithful to Dionysius. According to Berthold, "the invisible things of God" can be taken in two ways, intransitively or transitively (intransitive vel transitive). ${ }^{137}$ Regarding their intransitive sense, Augustine and Dionysius were clearly in agreement. For Augustine, these invisible things are the eternal, unchangeable reasons in the Word (rationes aeternae et incommutabiles in Verbo Dei Patris), which Dionysius called "exemplars pre-existing in God". 138

The situation for the invisibilia Dei understood transitively was more complex. Berthold framed the discussion around De divinis nominibus 11.6, where Dionysius responded to a letter requesting clarification about what he meant when he sometimes said that God is life itself (per se vita) and, at other times, that God is the substantiator (substantificator) of life itself. ${ }^{139}$ Berthold will bring two more passages into play momentarily: De divinis nominibus 5.5 (read alongside the glosses of Maximus) and Epistula II, which also treats the problem raised in the letter mentioned by Dionysius. Berthold began, however, by citing Thomas Gallus, the Eriugenian De causis primis et secundis (which he attributed to Al-Farabi), and finally Maximus. All three texts referred explicitly to Dionysius and, satisfying the demands of Berthold's literal method, all three used the term invisibilia:

But if the invisible things of God are taken transitively, in this sense, according to Thomas Gallus commenting on chapter 11 of On the

136 Albert the Great, Super Dionysium De divinis nominibus, 5.24, p. 316, l. 64 - p. 317, l. 11; id., Summa theologiae, pars I, tr. 13, q. 55, m. 2, a. 1, p. 56oa; Thomas Aquinas, In librum De divinis nominibus Expositio, c. 1, lect. 2, §72, p. 21; c. 2, lect. 1, §113, p. 39; c. 9, lect. 1, §807, p. 301.

137 Berthold of Moosburg, Expositio, Prol. 3, p. 7, l. 78.

138 Berthold of Moosburg, Expositio, Prol. 3, p. 8, l.105 - p. 9, l. 120. Albert the Great presented the same dossier (Dionysius, Maximus, and Augustine): Summa theologiae, pars I, tr. 13, q. 55, m. 2, a. 1, p. 559b-561b; id., Summa theologiae, pars II, tr. 1, q. 4, m. 1, a. 2, p. 72a-77a; id., In I Sententiarum, d. 35, a. 7, p. 189a-191b.

139 Dionysius, De divinis nominibus, 11.6, 953B. 
Divine Names, 'the divine Good is said to be the Substantiator', namely, 'of his invisible things, which are the rays, so to speak, of superunified Goodness, such as per se being, per se life, and so on'. Al-Farabi discusses these invisible things in his treatise On the Cause of Causes, which begins, 'The Principle of principles', and states the following: 'Therefore, there are exemplars, the primary causes of things'. And below: 'The first causes, because of their infinite diffusion over all things and the incomprehensible height of the ineffable purity of their excellence, are not perceived by intellect, because they are not outside the First, who formed them in the principle.' And below: 'The invisible things are hidden away in the shadows of his excellence, but in their effects - brought forth, as it were, into a certain light of cognition - they ceaselessly appear'. Thus Al-Farabi. Concerning these primordial causes, which Dionysius calls 'per se power', 'per se being' or 'being-itself', etc., and 'the principles of beings', Dionysius himself says the following in chapter 5 of On the Divine Names: 'and being-itself is more ancient than per se life, and more ancient than per se wisdom? ${ }^{140}$

Like Thomas Gallus, Berthold clearly stated that the Good is the cause of these principles or processions; we have already seen Berthold discuss this in terms of efficient causality. In On the Divine Names 5.5 he found the precedent for positing a rank among the primordial causes. But once again he will elaborate this beyond anything he would find explicitly in Dionysius.

Before this, however, Berthold cited the first Eriugenian text of the Expositio, the De causis primis et secundis. This text, in addition to explicitly harmonising Augustine and Dionysius (notwithstanding it attribution to $\mathrm{Al}$ Farabi, which Berthold never questioned) offered the crucial description of

140 Berthold of Moosburg, Expositio, Prol. 4, p. 9, l. 134-149: Si vero accipiantur invisibilia Dei transitive, quorum secundum Vercellensem super 11 cap. Dionysii De divinis nominibus 'divina bonitas dicitur esse substantificatrix', scilicet 'suorum invisibilium quasi radiorum superunitae bonitatis, ut sunt per se esse, per se vita, etc.' - de quibus invisibilibus prosequitur Alfarabius in libello De causa causarum, qui incipit: 'Principium principiorum,' sic inquiens: 'Sunt igitur exempla causae rerum primariae'; et infra: 'Causae primae propter infinitatem super omnia diffusionem et incomprehensibilem altitudinem ineffabilis puritatis suae excellentiae nullo percipiuntur intellectu eo, quod non distant a primo, qui eas in principio formavit'; et infra: 'Invisibiles res in tenebris excellentiae suae absconditae sunt, in effectibus autem suis veluti in quandam lucem cognitionis prolatae non cessant comparere': haec ille -, de istis causis primordialibus, quas Dionysius vocat 'per se virtutem,' 'per se esse' seu 'secundum se esse', et huiusmodi et 'principia existentium, sicit dicit ipse Dionysius 5 cap. De divinis nominibus: 'Et est ipsum secundum se esse senius eo, quod est per se vitam esse, et eo, quod est per se sapientiam esse? 
the two-sided and transitional nature of these exemplars. ${ }^{141}$ The passage he cited from the treatise derived ultimately from Periphyseon II $\left(55^{\circ} \mathrm{C}-55^{1 A}\right.$ and $55^{2} \mathrm{~A}$ ), which contained Eriugena's commentary on the meaning of the "shadows" and "abyss" in Genesis 1:2. A briefer version of this passage was taken over into the Clavis physicae, which Berthold marked with a marginal cross (Ms Paris, BnF lat. 6734, f. 35v). Berthold's text of the De causis primis et secundis, however, as Ezequiel Ludueña observed, evidently included a phrase not found in the modern edition of Roland de Vaux or, for that matter, in the Clavis: the invisibilia are shadows and abysses diffusing through and above all things, and are unknowable "because they are not distant from the first" (eo, quod non distant a primo)..$^{142}$ This final clause allowed Berthold to account for the identity and distinction between the primordial causes and God, and to harmonise Dionysius with what he found, for example, in Propositions 123 and 162 of the Elementatio theologica, which speak of the gods as hidden in their superior or unitive aspect but manifest in the character of the pluralities they produce. That is, as "good", the primordial causes remain hidden in their source; as the cause of infinity, being, life, and so on, they are known from their effects.

Berthold gave a longer citation of the De causis primis et secundis in Proposition 56 ("Everything that is produced by secondary causes, is produced more eminently by prior and more efficacious causes, from which the

141 Al-Farabi must have been a complex figure in Berthold's mind. As the supposed author of De causis primis et secundis, he deserves the highest praise for describing the relation of the primordial causes to God in precise terms. However, as the supposed author of the Liber de causis, which categorically affirms that the "first of created things is being", he must belong with "unlearned" who are "sealed off in beings". See the table of Philosophifamosi in Berthold of Moosburg, Expositio, p. 4, l. 40-41: Alfarabius De causa causarum / item De causis; and ${ }_{71 D}$ D, p. 35, l. 123-127, cited above in Introduction, section 3, n. 15o. Cf. Expositio, 57B, p. 15o, l. 94-96: Licet etiam ista sint subtilius dicta prius et secundum intentionem auctoris De causis, tamen non sunt de absoluta consideratione istius auctoris, qui non ponit causas primarias proprie nisi ipsas bonitates propter earum simplicitatem.

142 Ludueña, La recepción de Eriúgena, p. 328-338. Cf. Honorius Augustodunensis, Clavis physicae, c. 86, p. 61, l. 3-6: que abyssus dicuntur propter incomprehensibilem altitudinem infinitamque sui per omnia diffusionem, que nullo percipitur sensu, nullo comprehenditur intellectu, tenebre autem propter ineffabilis sue puritatis excellentiam. See also De causis primis et secundis et de fluxu qui consequitur eas, ed. R. de Vaux, Notes et textes sur l'avicennisme latin aux confins des XII ${ }^{-}-X I I I^{e}$ siècles, c. 2, p. 92, 1. 12-16: cause rerum prime propter infinitam sui diffusionem et incomprehensibilem altitudinem et ineffabilis puritatis excellentiam, nullo percipiuntur intellectu, excepto illo qui eas in principio formavit. Since Berthold could have modified the parallel passage in the Clavis to suit this purpose, one can assume that the phrase was found in his copy of De causis primis et secundis. 
secondary causes were produced"), ${ }^{143}$ which clarified his interpretation of this passage:

After Al-Farabi shows that [1] the exemplars of all things exist in the first wisdom, in which all things are known as in their first exemplars, just as things caused are known in their first causes, he immediately says what these are: [2] 'The exemplars are, therefore, the first causes of things'. And below: [3] The first cause was never 'without the first causes of things that were made in it'. And shortly thereafter: 'The first causes, because of their infinite diffusion over all things and the incomprehensible height of the ineffable purity of their excellence, are not perceived by intellect, because they are not outside the First, who formed them in the principle'. [4] This is because in their effects or in their processions into intelligible forms, only their existence is known, not their essence, and [5] thus the primary causes come forth in those things, of which they are the causes, and they do not leave the first, namely, wisdom. ${ }^{144}$

This specifies [1] that the exemplars of all things exist in the divine mind, [2] that these exemplars are the first causes of things, and [3] that the first cause was never without these primordial causes made in it. ${ }^{145}$ All of this would apply to the intransitive sense of invisibilia that denotes the living, eternal reasons of things existing in the Word. Their transitive aspect came into view when Berthold wrote [4] that from the phenomenal world of intelligible forms, species, and definitions, one can only infer that these causes exist without grasping their quiddity. [5] Therefore, the primary causes are manifest in their effects but do not depart from the wisdom or mind of God. The epistemological point

143 Proclus, Elementatio theologica, prop. 56, p. 30, 1. 1-3: Omne quod a secundis producitur et a prioribus et a causalioribus producitur eminentius, a quibus et secunda producebantur.

144 Berthold of Moosburg, Expositio, 56D, p. 144, 1. 137 - p. 145, l. 148: Postquam ostendit [Alfarabius] [1] in prima sapientia esse omnium rerum exempla, in quibus sicut primis exemplis sciuntur omnia sicut causata in primis causis, statim subinfert, quid sint talia exempla dicens: [2] 'Sunt igitur exempla causae rerum primariae'. Et infra: [3] Causa prima numquam fuit 'sine prioribus rerum causis in se factis'. Et parum infra: 'Causae primae propter infinitam super omnia diffusionem et incomprehensibilem altitudinem ineffabilis puritatis suae excellentiae nullo percipiuntur intellectu eo, quod non distant a primo, qui eas in principio formavit.' [4] Quod autem in effectibus, hoc est in processionibus earum in formas intelligibiles cognoscuntur solummodo, quia sunt, non autem, quid sunt, et [5] sic principales causae in ea, quorum sunt causae, proveniunt, et primum, id est sapientiam, non reliquunt.

145 See also Berthold of Moosburg, Expositio, 99H, p. 202, 1. 152-159, where the primordial causes were described as "uncreated". 
at [4] brings us to the cusp of the transition from the intransitive, archetypical world and the transitive procession of creatures. In this way, the De causis primis et secundis has provided the basic insight about the primordial causes that Berthold will elaborate with principles derived from Propositions 64 and $65 .{ }^{146}$ The Good (causaliter) is properly diffusive only of goods (bonitates per essentiam and bonitates per participationem) while these goods are in turn the causes that strengthen the irradiations of the Good that are too weak to subsist by themselves. Like the Good, the gods are only known imperfectly by their processions. ${ }^{147}$ But since each god generates its own more limited "universe" by a superabundance of a formal intention, it is in fact better known than the Good. ${ }^{148}$ According to Berthold's theory of formal intentions, a primordial cause is one in re et intentione with what it essentially participates, namely, the Good itself. ${ }^{149}$ The notion of a unitas or bonitas per essentiam thus can serve the transitional function of being both a transcendent principle as a formal cause (identical with the One-Good as unum or bonum) but, insofar as it is an effect of the One-Good as an efficient cause (a god is not bonitas per causam but per essentiam), it has a limited or supposited nature. This duality explains how each god initiates its own characteristic intention from itself - the nearer a bonitas per essentiam is to the One, the greater the influence of its causal

146 Dionysius, De divinis nominibus, 13.3 was Berthold's preferred text for showing that Dionysius held that intention of "one" or "good" subsists in three modes. See Berthold of Moosburg, Expositio, 113E, p. 37, 1. 157 - p. 38, 1. 160: Et attende diligenter, quod sic enucleate distinguit [Dionysius] triplex unum, scilicet prime unum, quod vocat supersubstantiale unum et omnium causam, et existens unum, scilicet primo et per se unum, supra quod dicit esse prime unum sicut terminans ipsum, et quod est participans unum. See also, for example, Expositio, 1D, p. 77 , l. 226 - p. 78, l. 246; 5 D, p. 120 , l. 245 - p. 121, l. 282; 64F, p. 197, l. 149-154.

147 Berthold of Moosburg, Expositio, 162I, p. 21, l. 183 - p. 22, l. 188.

148 Berthold of Moosburg, Expositio, 123L, p. 133, l. 295 - p. 135, l. 348.

149 Berthold of Moosburg, Expositio, 2B, p. 84, l. 97-9: Quoddam enim participans et quo essentialiter participat, id est participans et participatum, sunt unum re et intentione. Et est summus modus participandi conveniens solum primordialibus causis. See also Expositio, ${ }_{125}$ D, p. 149, 1. 83-120: omne activum prius natura transfunditur in se ipso, quam redundet ad extra [...], ideo interior emanatio in ipsis diis est ratio et causa emicationis sive processus causalis, qua de occulto supersubstantialis unionis quilibet deus emicat se ipsum. [...] Sic ergo 'omnis deus existens unitas per se perfecta' per 114 et 'primordialis causa' per 97 tradendo 'universo ordini' suo propriam 'proprietatem' [...]. Et hoc est, quod dicit Theodorus in Clave loquens de primordialibus causis: 'Primae causae in se ipsis unum sunt et simplices nullique cognitio ordine definitae aut a se invicem segregatae: haec enim in effectibus suis partiuntur. [...] primordiales causae in principio omnium, scilicet in Verbo Dei, unum simplex atque individuum sunt, dum vero in effectus suos in infinitum multiplicatos procedunt'; ${ }_{117} \mathrm{C}, \mathrm{p} .69$, l. $54-$ p. 70, l. 61 . 
efficacy. ${ }^{150}$ By distinguishing each primordial cause (e.g., per se esse, per se virtus) as good from its intention as causal primordial principle, Berthold found an elegant account of the relation of God's wisdom to its processions that did not reify one apart from the other but preserved their dynamic relationship.

After citing the De causis primis et secundis in Prologus 4, Berthold cited a lengthy Eriugenian gloss to De divinis nominibus 5.5, in which the primordial causes are identified with the divine ideas and the processions. ${ }^{151}$ This comment, under the authority of Maximus, provided the crucial terminological equivalency between causae primordiales, ideae, formae aeternae, principalia exempla, situated these in the Word prior to the multiplying work of the Holy Spirit, and concluded by placing the entire doctrine under the shared authority of Dionysius and Plato. ${ }^{152}$ Not only was the Triune nature of God known to Plato, but so was the view that there are primordial causes that arise within the Trinitarian processions that will refract its causality.

Berthold then turned to De divinis nominibus 11.6 and the question of God's relation to these causes or per se principles. ${ }^{153} \mathrm{~A}$ feature of Dionysius' text prudently omitted by Berthold was the critique of the view that the cause of life, for example, is "a deity besides the super-divine life". Dionysius had explicitly denied that these principles of beings are "creative substances and persons, which [some] called the gods of beings and per se active creators". ${ }^{154}$ Berthold

150 The Clavis had not emphasised the internal division in each primordial cause into a creative and a created aspect. See S. Gersh, "Honorius Augustodunensis and Eriugena. Remarks on the Method and Content of the Clavis Physicae", in W. Beierwaltes (ed.), Eriugena redivivus. Zur Wirkungsgeschichte seines Denkens im Mittelalter und im Übergang zur Neuzeit. Vorträge des V. Internationalen Eriugena-Colloquiums, Werner-Reimers-Stiftung, Bad Homburg, 26.-30. August 1985 (Heidelberg: Winter, 1987), p. 162-173. Berthold's interpretation of the De causis primis et secundis and its phrase eo, quod non distant a primo thus brought him closer to Eriugena himself than the Clavis could.

151 Berthold of Moosburg, Expositio, Prol. 4, p. 10, l. 155-174. Cf. Eriugena, Periphyseon, lib. II, 615D-617A, p. 124, l. 3142-3188, and Honorius Augustodunensis, Clavis physicae, c. 116, p. 85, l. 4 - p. 86, l. 39. Another portion of Clavis c. 116 was used concerning participation at 2A, but it is only cited in full at Expositio, 128A, p. 166, l. 12 - p. 167, l. 57, alongside De divinis nominibus, 5.8-9 on the exemplars in God.

$15^{2}$ Berthold of Moosburg, Expositio, Prol. 4, p. 10, l. 165-169: 'Ideae a philosophis divinae voluntates appellari solent et praecipue a Platonicis, quoniam quaecumque voluit Deus facere, in ipsis principaliter et causaliter fecit'. Et infra: 'Has formas sive ideas Dionysius ceterique sancti appellant per se ipsam bonitas, per se ipsam essentia [...]'.

153 Coincidentally, in Periphyseon, lib. II, 617A-C, immediately following the passage that became the source for the scholium just mentioned, Eriugena also appealed to the authority of Dionysius and cited De divinis nominibus, 11.6 at length. This was not taken over into the Clavis.

154 For this reason, Albert the Great, Super Dionysium De divinis nominibus, 11.27, p. 424, 1. 80 p. 425 , 1. 36, placed Dionysius with Aristotle against the idolatrous "followers of Hesiod" 
preferred to cite and slightly modify Dionysius' positive statement that immediately followed: being itself (per se esse) can be said divinely and causally (divine et causaliter) of God himself, and divinely and participably (divine participabiliter) of the providential powers of the unparticipable God. ${ }^{155}$ This would correspond neatly to Berthold's own distinction of intransitive and transitive invisibilia. The primordial causes as intransitive are the divine wisdom or the archetypical world and are one (unum in re) with the divine essence. But as causes, they are transitive, and are the Good as "divinely participable". In this passage, Dionysius had reported the teaching of some of his "divine, holy masters": 156 they called the substantificator of per se bonitas and per se deitas "the Beyond-good" (superbona) and "the Beyond-deity" (superdea), and called per se bonitas itself "the beneficent and deifying gift coming from God". ${ }^{157}$ As Berthold interpreted him, Dionysius had thus posited some form of a subordination of these principles to God. Berthold presented this interpretation as consistent with Dionysius' Epistula II to Gaius, which outlined how God is above the "thearchy" - taken as a synonym for the primordial causes, deities, goodnesses and beneficent, deifying gifts of the unparticipable God. 158

and the Platonists. Thomas Aquinas, In Librum De divinis nominibus Expositio, c. 11, lect. 4, $\S 931-933$, p. 346, also interpreted this passage as a critique of the Platonists. See V. Boland, Ideas in God according to Saint Thomas Aquinas. Sources and Synthesis (Leiden: Brill, 1996), p. 299-303; Hankey, "The Concord", p. 163-169.

155 Berthold of Moosburg, Expositio, Prol. 4, p. 10, l. 179-180. Ludueña, La recepción de Eriúgena, p. $343^{-7}$, has noted a crucial variant: where Saracen's translation reads participaliter autem datas ex deo imparticipabili provisivas virtutes, Berthold has divine vero participabiliter datas. As Ludueña indicated, participabiliter appears in Albert the Great, Super Dionysium De divinis nominibus, 11.27, p. 424, 1. 74 and p. 425, 1. 41. Berthold's only other citations of De divinis nominibus, 11.6 - in Expositio, 63B, p. 187, l. 35 - p. 188, 1. 52; and 113A, p. 34, l. 35-44 - both read particulariter, although this may be the result of a copyist's error. Berthold's passing reference to De divinis nominibus, 11.6 at Expositio, 23A, p. 113, 1. 55-57 suggests that he generally intended participabiliter as the correct reading.

156 Albert the Great, Super Dionysium De divinis nominibus, 11.29, p. 425, l. 66-68, and Thomas Aquinas, In Librum De divinis nominibus Expositio, c. 11, lect. 4, §938, identified these individuals with Hierotheus and other disciples of the Apostles.

157 Berthold of Moosburg, Expositio, Prol. 4, p. 11, l. 186-196.

${ }_{15} 8$ Albert's comments on the Epistle focus on the problem of deification, and how deitas can be regarded as both created and uncreated. His solution distinguishes between the formal and efficient senses of "the principle of deification". God is said to be above the formal principle which is "the [created] participation of deity assimilating to God through grace or glory", while he is identical with the thearchy as the efficient cause of deity. See Albert the Great, Super Dionysii Epistulas, Epistula II, p. 483, l. 49-58. For Berthold, Epistula II referred to the self-sufficient gods (deus per essentiam) as formal causes and to their dependency on God as their efficient cause (deus per causam). 
Since Berthold was of course aware of Dionysius' outright rejection of any deity besides (praeter) God, he knew he must tread lightly. He would explicitly invoke the Proclean term "gods" for the first time only after citing the Psalms 95:3 and 97:9 that praise God as "far exalted above all gods", and in Psalm 50:1 as the Lord of gods (Deus deorum dominus), and after citing Paul, who subordinated "the gods in heaven and earth" to "our one God and Father, from whom are all things and we in him, and one Lord Jesus Christ, through whom are all things and we through him" (1 Cor. 8:5-6). ${ }^{159}$ The same gods mentioned by Paul (isti di), Berthold declared, are for Proclus "beyond beings and the measures of being, for every being is in them as number is in the monads, though beings proceed from them". Then there followed the pivotal text from De decem dubitationibus 10.63, where Proclus used the same principle found in Proposition 64 to establish that "one" and "good" exists in three ways: according to cause, existence, and participation.

Berthold anticipated that his readers would be uncomfortable with admitting the existence of "gods by essence". He invoked Boethius' remarkable argument in the Consolatio philosophiae that everyone in bliss is god (omnis beatus deus) to illustrate how there can be one God "by nature" and many gods as you please "by participation". "If you object", Berthold remarked, "that therefore there are [still] no gods by essence, I say that this does not follow, since every god by essence participates deity because it does not have deity in its superabundance". 160 The gods are subordinate to the immediate efficient causality of the Good - they participate or limit its superabundance - and do so in such a way that they are not distant from the first. That is, as formal causes constituted out of the single intention of "one" or "good" they refract the divine Light by proportionately exercising the same spontaneous and generative activity of the Good. In this way, Berthold's original interpretation of his Eriugenian sources (especially the Liber de causis primis et secundis) in terms of the distinction of formal intentions ("good", "infinite", etc.) and the relation between formal and efficient causality established the accord of Proclus and Dionysius on one of the central themes for the Elementatio theologica that would be most difficult for his contemporaries to accept: the existence of primordial causes that are divine by their essence.

At the heart of Berthold's determinedly Platonic approach to the separate substances was Proposition 65 ("Everything that subsists in any way, subsists principaliformiter according to cause, or according to essence, or according to

159 Berthold of Moosburg, Expositio, Prol. 4, p. 12, l. 218-226.

16o Berthold of Moosburg, Expositio, Prol. 4, p. 13, l. 248-25o. In 2A, p. 83, l. 48-53, this limitation of the higher by the lower is called the third "mode" of participation. 
participation in an exemplary way"). ${ }^{161}$ The same idea appeared also in Proclus' proof to Proposition 140, which Dietrich of Freiberg had cited as the exhaustive enumeration of the possible modes of any essential order. ${ }^{162}$ For Berthold, the principle is "so obvious that it is in no need of proof". 163 Berthold's elaboration of Dietrich's theory, after it has been subjected to the Platonic critique of the universality of abstraction and the metaphysics of being, would be impossible without this principle, which provided the law of proportionality that captured the way in which the separate substances must be truly ordered among themselves, independently of our thinking.

It was with these principles from Propositions 62-66, having established for the first time in the Prologus that the primordial causes or gods were in fact posited by both Proclus and Dionysius, that Berthold schematised the array of separate substances. ${ }^{164}$ As the final link in his catena of citations from Gallus, the De causis primis et secundis, the glosses of Maximus, Dionysius, the Scriptures, and Proclus, Berthold gave a heavily glossed citation of De divinis nominibus 11.6 and interpolated the entire population of natural providence into the Areopagite's text, from the six primordial causes, to their orders, to the self-subsistent members of those orders, and finally their participants. Despite his efforts to show that this simply was the common teaching of Proclus and Dionysius, Berthold's proportional reasoning about the relationship between God's unlimited causal influence and the limited influence of primordial causes in their partial universes was the teaching for which he himself will be cited in an anonymous commentary on the Sentences from 14th-century Regensburg. ${ }^{165}$

161 Proclus, Elementatio theologica, prop. 65, p. 35, l. 1-3: Omne quod qualitercumque subsistit aut secundum causam est principaliformiter aut secundum existentiam aut secundum participationem exemplariter.

162 Dietrich of Freiberg, De intellectu et intelligibili, II.1.2, p. 146, 1. 14-19: Plures modos non invenimus in essentialiter ordinatis; II.7.4, p. 151, l. 66-73. Berthold of Moosburg, Expositio, 65 F, p. 204, l. 109-114, concluded by finding this logical triad also in Dionysius, Epistula IX.2, $1108 \mathrm{~B}$.

163 Berthold of Moosburg, Expositio, 74C, p. 54, l. 137-142: Ubi primo notandum et quasi pro fundamento ponendum, quod omne, quod qualitercumque subsistit, aut secundum causam principaliformiter aut secundum essentiam aut secundum participationem exemplariter per 65. Sed species, de qua agitur, subsistit tam in causa principaliformiter quam in participantibus exemplariter, et hoc vere et secundum rem. Hoc enim ita manifestum est, quod etiam non indigent probatione.

164 Berthold of Moosburg, Expositio, Prol. 4-5, p. 12, l. 227 - p. 13, l. 263. Proclus, De decem dubitationibus circa providentiam, q. 10, §63 yields Propositions 64 and 65 (1. 231-242); Berthold applied Proposition 65 to Boethius, Consolatio philosophiae, lib. III, prosa 10 (l. 243-250), and Propositions 62 and 66 to Dionysius (1. 254-263).

165 Berthold of Moosburg, Expositio, 8D, p. 162, l. 178-209. See Conclusion, section 1, below. 
Just as Berthold used these Eriugenian sources to establish the subtle boundary between God and the highest of his works, so he also employed the Clavis to account for the dynamic presence of the Good as it moves through these causes or instruments of its causality:

Divine goodness and essence and life and wisdom and everything, which are in the font of all, first flow forth into the primordial causes and make them to be, then through the primordial causes into their effects in an ineffable way. 166

That is, the same Good courses through all things providentially. Since these causes, insofar as they are unities or goodnesses, are not strictly other than God, "in a broad sense" God is said to become (fieri) through them in his providential and creative procession (processus seu exitus). The procession of a cause "from the secrets of its eminence into an effect" is said not only of the primordial causes, "which are said to be made [fieri], since they essentially multiply themselves in their effects," but also of "God by his providence [...] as Dionysius says in the Letter to Titus". 167 In this respect, Dionysius' twofold usage of the term "procession" (effects proceed from a cause; a cause proceeds into its effects), ${ }^{168}$ was transmitted to Berthold through his Eriugenian sources. This is what undergirded his view about the ineffability at the depth of each thing (usia) by virtue of its immediate relation to the Good. ${ }^{169}$

166 Berthold of Moosburg, Expositio, 18B, p. 47, l. 112-5 = Honorius Augustodunensis, Clavis physicae, c. 126, p. 94, l. 13-6.

167 Berthold of Moosburg, Expositio, 3A, p. 92, l. 14-19: tunc est processus seu exitus rei existentis in actu ex secretis suae eminentiae in effectum, et sic non solum causae primordiales dicuntur fieri, cum se ipsas per essentiam multiplicant in effectus, sed etiam Deus ipse sua providentia, quae 'perfecta est', ut dicit Dionysius in Epistula ad Titum, quae est causa, ut sint omnia, et ad omnia procedit et in omni fit et continet omnia.

168 S. Gersh, "Ideas and Energies in Pseudo-Dionysius the Areopagite", in Studia Patristica 15(1984), p. 297-300.

169 Berthold of Moosburg, Expositio, 120D, p. 98, 1. 255 - p. 99, 1. 268: Non est autem alia providentia omnium et alia causa omnium, sed unus atque idem Deus, qui in omnia procedit et in omni fit [...]. Lux ineffabilis omnibus intellectualibus oculis semper praesens et a nullo intellectu cognoscitur, quid sit, per omnia diffusa in infinitum et fit in omnibus omnia; 120E, p. 100, 1. 306-8: Deus ex superessentialitate suae naturae, qua dicitur non esse primum descendens, in primordialibus causis a se ipso creatur et fit principium omnis essentiae; 123M, p. 136, l. 367-382: Dum ergo incomprehensibilis intelligitur, per excellentiam nihilum non immerito vocatur; atvero suis theophaniis incipiens apparere, veluti ex nihilo dicitur aliquid procedere, et quae proprie super omnem essentiam existimatur, proprie quoque in omni essentia cognoscitur. [...] Ipse factor omnium in omnibus factus. On the ineffability of usia, see $121 \mathrm{E}$, cited at 4.2, n. 50, above. 
This Platonic consensus on the Trinity and the primordial causes was the standard Berthold used when he incorporated Dietrich of Freiberg's notion of the essentially active intellect (intellectus in actu per essentiam) as an imago Trinitatis into his commentary. Dietrich had used this notion explicitly to interpret what Proclus meant by the gods in the Elementatio theologica. ${ }^{170}$ According to Dietrich, when Proclus spoke of "gods" he simply appropriated the term to "inferior substances, namely the intelligences", in order to indicate that the One was beyond the names "intellect" and "god". ${ }^{171}$ Berthold departed from Dietrich by assimilating Proclus' gods to the primordial causes or divine processions of Dionysius and not to the intelligences of the Liber de causis. ${ }^{172}$ This coincided with Berthold's extensive elaboration of one of Dietrich's own conceptual inventions, the notion that a certain set of separate substances can be understood ontologically as beings existing as a species (entia secundum speciem). Adopting this notion, Berthold will argue for the subordination of the separate intellects to the gods considered in terms of their constitutive formal intentions: the gods are constituted by one formal intention ("one" or "good"), and the intelligences out of many ("good", "power", "being", "life", and "intellect"). But this clear subordination of intelligences to the gods according to the dictates of Platonic reasoning came at the cost of a proliferation of separate principles that then must exist between the gods and intelligences (the orders of separately subsisting "infinities", "beings", and "lives"). These we found enumerated in the table at $62 \mathrm{C}$, but now we will look more closely at Berthold's justification for positing their existence.

170 Dietrich of Freiberg, De intellectu et intelligibili, 1.7.1, p. 140, 1. 21-28: illae intellectuales substantiae, quas philosophi intelligentias vocabant, de quibus agitur in Libro de causis et in libro Procli, quas in pluribus locis illius libri deos nominat, quamvis secundum diminutam et imperfectam rationem deitatis, sicut etiam Philosophus in XII Metaphysicae approbat dictum illorum, qui vocabant principia moventia caelos, vocabant, inquam, deos secundum diminutam et imperfectam rationem deitatis.

171 Dietrich of Freiberg, De cognitione entium separatorum, 9.2, p. 175, l. 70 - p. 176, 1. 81: Unde attendendo hanc Dei immensitatem Proclus in libro suo superordinavit omnibus intellectibus et secundum substantiam et secundum operationem quadam inexplicabili positiva nominis proprietate essentiam divinam dicens propositione $20:[\ldots]$ et omnibus intellectualibus hypostasibus superius ipsum unum. Ecce, caruit nomine positivo, quo exprimeret illam summam essentiam, quae Deus est, caruit, inquam, secundum intentionem suam, nec suffecit sibi nomen intellectus, immo nec nomen Dei, quae duo nomina appropriate inferioribus substantiis, id est intelligentiis, in processu eiusdem libri sui propositione 121[125], 130 [134], 136[140], 141 [145], et ibi in commento, ubi dicitur: 'Plena autem sunt omnia diis, et quod unumquodque habet secundum naturam, inde habet'.

172 E. Ludueña, "Creatio y determinatio en la Escuela Renana. De Alberto Magno a Bertoldo de Moosburg”, in Princípios. Revista de Filosofia, 22/37(2015), p. 77-97, at p. 87-94. 
Moving below the thearchy (God and the gods) to the numerous orders of entities that Berthold posited in the realm of being (from infinities to human nature) above the realm of becoming (nature and human individuals), we are immediately confronted with the question of the relationship between the creative causality of the One and the determinative causality exercised by the first of the primordial causes. Berthold identified this primordial cause - the prima unitas as distinct from the prime unitas or "the primarily God" - as "infinity" or the Unlimited. In so doing, he proposed a solution to a puzzle that has vexed Proclus' medieval and modern interpreters, namely, how to produce a coherent account of the relationship between the pair of Limit and the Unlimited ( $\pi \dot{\varepsilon} \rho \alpha \varsigma-\alpha \dot{\alpha} \pi \varepsilon ı \rho \vee v)$, discussed mostly in Propositions 89-92, and the gods. Proclus' most explicit statement about their relation in the Elementatio theologica at Proposition 159 ("Every order of gods is from the first principles, Limit and the Unlimited, but some relate more to the causes of Limit, others to the causes of the Unlimited"), ${ }^{173}$ has left his commentators from the time of Nicholas of Methone (d. 116o/1166) somewhat baffled, since it would seem to locate these two principles somewhere between the One and the gods, whose relation to the One was supposedly immediate. ${ }^{174}$

As the situation has been recently described by Jonathan Greig, there are two problems that confront Proclus' interpreters on this point. ${ }^{175}$ The first concerns the reconciliation of two apparently distinct causal models: one in which each supersubstantial god unites a series of entities that emerge from it and share its unique characteristic, and another in which Limit and the Unlimited are the immediate causes of the mixture of Being. The second problem is to avoid an undesirable consequence that could be drawn from in Proposition 159: if the orders arising from the gods are composed of Limit and the Unlimited, this would entail at least some composition in the gods themselves as principles of those orders. If so, this would mean that the gods are not in fact pure unities. ${ }^{176}$

173 Proclus, Elementatio theologica, prop. 159, p. 78, 1. 1-2: Omnis ordo deorum ex primis est principiis, fine et infinitate; sed hic quidem ad finis causas magis, hic autem ad infinitatis.

174 See E.R. Dodds' commentary to Proposition 159, in Proclus, The Elements of Theology, ed. E.R. Dodds (Oxford: Clarendon Press, $1963^{2}$ ), p. 281.

175 See J. Greig, "Proclus on the Two Causal Models for the One's Production of Being. Reconciling the Relation of the Henads and the Limit/Unlimited", in The International Journal of the Platonic Tradition 14(2020), p. 23-48, at p. 23-28.

176 Greig, "Proclus on the Two Causal Models", p. 28-31. 
Let us call the first the "integration" problem, and the second the "simplicity" problem.

Although Berthold did not directly raise these questions, we will see that they nevertheless provide a helpful way of summarising the advantages and shortcomings in his interpretation of Proclus on the Limit and the Unlimited. Berthold's proposal, in short, was that the One (prime unitas) should be identified as the Limit that produces a series of limits, which are the gods or primordial causes, and that the first primordial cause (prima unitas) should be identified as the Unlimited. This allowed him to avoid the integration problem altogether by maintaining that Proclus was in fact not outlining two different models of causality. There was one causal pattern derived from the principles of essential order and proportionality in Propositions 62-66, and this applied as much to the gods as to all other members of the essential order of natural providence. Each primordial cause generates a series from its own characteristic intention - in the case of the Good, this produces the intermediary principles (bonitates per essentiam) that, since they are substantial goods, refract its causal power. Each primordial cause also leaves a trace of its intention in every principle and order subordinate to it. This allowed Berthold to say that the primordial cause of being (prime entitas) and order arising from it, which follows immediately after the order of infinitas, is indeed constituted by Limit and the Unlimited (Proposition 89) precisely because Limit and the Unlimited leave a trace of their influence in every order of the gods (Proposition 159).

This proposal, however, led Berthold into some difficult territory relative to the "simplicity" problem. Berthold would want to maintain that his account of formal intentions did in fact preserve the unicity of each god as constituted from only the intention of "one" or "good", even though each god is subordinate to the One according to its own degree of "contraction". ${ }^{177}$ We may again recall the table of six formal intentions in $62 \mathrm{C}$, whose number at other times expanded to include the seven "pillars" or formal perfections of the house of God (unitas/bonitas, virtus, entitas, vita, intellectualitas, animealitas, and naturalitas). All that was required was to show that the first two intentions could be assimilated to the Limit and the Unlimited. But as soon as Berthold made this assimilation, he introduced a linear structure of subordination among the primordial causes. The One (prime unitas) or Limit was the immediate cause of the entire order of the gods as "ones" or "limits". The highest member within that order (prima unitas), the primordial cause of infinity or power (virtus), as

177 Berthold received the terminology of "formal intentions" and "contraction" from Dietrich, who used it to interpret the Liber de causis. See Dietrich of Freiberg, De intellectu et intelligibili, II.16.1, p. 157, l. 28-35. 
both an essential unity (unitas secundum essentiam) and an originary formal cause (infinitas secundum causam), would fit Berthold's desired model perfectly. However, every subordinate primordial cause within that order beginning with prime ens must be, in Berthold's words, "almost" (quasi) composite, insofar as it presupposes the activity of both the One and infinity, which he identified as an "auxiliary cause" (concausa) within the order of gods.

Readers of Proclus today would no doubt see this very linear model as a major departure from Proclus' own more sophisticated henology, even though it was so advantageous for Berthold's articulation of a coherent theory of causality in Proclus relative to the integration problem. ${ }^{178}$ Proclus in his commentary on Plato's Parmenides advanced an important but nevertheless obscure distinction between the way in which the gods arise from the One, "according to union" ( $\kappa \propto \theta^{\prime} \varepsilon \tilde{\varepsilon} \nu \omega \sigma(v)$, and the way entities arise from the gods, by sameness and difference. ${ }^{179}$ Furthermore, for Proclus, since the precise number of henadic principles can only be known to the gods, ${ }^{180}$ it would seem preposterous to fix their number to six or seven. But this is exactly what Berthold was invited to do under the guidance of Proposition 135, which established a direct correlation between the number of gods and the number of the genera of being. ${ }^{181}$ In the spirit of Dietrich, Berthold would hold that the entire exercise of the oblique motion would be undermined if one could not reason necessarily about the invisible things of God beginning from the creation that was suffused with divine order and beauty. ${ }^{182}$ Ultimately, however, and perhaps

178 For the positions of C. D'Ancona, E. Butler, G. Van Riel, and an original solution to the problem in Proclus, see Greig, "Proclus on the Two Causal Models", p. 31-46.

179 Proclus, In Platonis Parmenidem commentaria, ed. C. Steel, 3 vols (Oxford: Oxford University Press, 2007-2009), vol. 1, lib. I, p. 644, l. 9-10; lib. II, p. 745, l. 14-23; vol. 3, lib. vI, p. 1049, 1. 26-27.

180 Proclus, In Platonis Timaeum commentaria, ed. E. Diehl (Leipzig: Teubner, 1903-19o6), vol. 3, p. 12, l. 27-30.

181 Berthold of Moosburg, Expositio, 135M, p. 230, l. 301-303. At 139D, Berthold addressed the possible confusion arising from his interpretation, which places between the gods and the "genus of beings" an intermediate "order of infinities", according to the order of formal perfections. With a citation from Clavis, c. 119, Berthold explains that the infinities can be spoken of as non-beings. This equivocation appeared to satisfy the commentator.

182 Berthold of Moosburg, Expositio, 109B, p. 13, l. 29 - p. 14, 1. 37: qui cum constituatur ex sex unitatibus, ut per declarationem 62 demonstratum est, necessarium est, quod in ipso tali ordine partes ipsius distributae sint secundum partes senarii aliquotas ita, quod primum sit unum tantum, 2 secunda et 3 tertia; 126F, p. 158, 1.146-147: ponatur sub exemplo descriptionis ordinis deorum, qui necessario constat ex sex diis; $139 \mathrm{D}, \mathrm{p} .35, \mathrm{l} .76-81$ : Hanc enim negare non possumus secundum intentionem auctoris, quia ad hoc praeter alia supra praemissa enumerata motiva cogit nos natura ordinis essentialis, quem necessarium est, sicut et in aliis, immo prae omnibus aliis in multitudine uniali deorum salvum esse. Quod non esset, nisi 
more in accordance with Proclus' own intent, Berthold understood that the oblique motion was itself the means to a higher apprehension. The content of this apprehension Berthold found described, not in Proclus' commentaries on Plato, but, as we will see, in the Clavis physicae, which taught him that reason necessarily divided what was in itself the unified movement of God as the beginning, middle, and end of all things. ${ }^{183}$

Berthold's interpretation of the propositions on the absolute Limit and Unlimited followed from his views about the six-fold order of the gods. His first lengthy discussion of the subject is found in Proposition 9o ("The first [prima] Limit and the first [prima] Unlimited exist prior to everything constituted out of limit and the unlimited"). ${ }^{184}$ Berthold's first inclination would no doubt have been to use the well-established distinction in the Expositio between

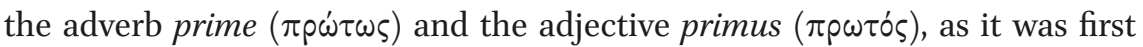
occasioned by Proposition 8. In such a view, the prima finitas mentioned in Proposition go should refer to the first effect of the primordial cause (e.g., prime finitas). However, in a rare departure from the letter of the Elementatio, Berthold proceeded directly to identify the One as prime finitas which, he argued, was what Dionysius had in mind when he spoke of the One limiting all things, including infinity (omnem quidem infinitatem terminans). ${ }^{185} \mathrm{He}$ further associated the causality of Limit with God's orderly arrangement of all things according to measure, number and weight. ${ }^{186}$ Using the law of proportionality in Proposition 65, he argued that the order of gods is in fact an order of limits (finitates), who would exercise the same dispositive power within their own domains. ${ }^{187}$

sex unitates contineret; 149F, p. 116, l. 165-172: Hoc igitur positio, cui non potest intellectus contradicere $[\ldots]$.

183 Berthold of Moosburg, Expositio, 125D, p. 15o, l. 103-109: Primae causae in se ipsis unum sunt et simplices nullique cognito ordine definitae aut a se invicem segregatae: haec enim in effectibus suis partiuntur. See also n. 216, below.

184 Proclus, Elementatio theologica, prop. 9o, p. 46, l. 1-2: Omnibus ex finitate et infinitate constantibus preexistit secundum se prima finitas et prima infinitas.

185 Berthold of Moosburg, Expositio, 9oA, p. 154, 1. 16 - p. 155, 1. 39: [...] Praemissis diligenter perspectis apparet ex sententia Dionysii prime unum, quod simpliciter omnia finit et terminat, esse prime finitatem. See also Expositio, 159H, p. 198, 1. 291-298, citing Dionysius, De divinis nominibus, 13.1 and 13.3.

186 Berthold of Moosburg, Expositio, 159H, p. 199, l. 308-311; 123K, p. 133, l. 271-287.

187 Berthold of Moosburg, Expositio, 9oC, p. 156, l. 90 - p. 157, l. 91. Incidentally, we may note that Proclus sometimes wrote that the Limit is more like the One. See Proclus, Théologie platonicienne, eds H.D. Saffrey, L.G. Westerink, vol. 3 (Paris: Les Belles Lettres, 1978), lib. III, c. 8, p. 33, l. 1-2; id., In Platonis Timaeum commentaria, vol. 1, p. 176, l. 11-12; id., In Platonis Parmenidem commentaria, vol. 1, lib. II, p. 738, l. 18-34; vol. 3, lib. vI, p. 1124, l. 6. 
According to Berthold, the first unity (prima unitas) among these gods or limits is power or infinity (prime virtus, infinitas). He presented this as the shared doctrine of Proclus, Dionysius, and the Clavis physicae. ${ }^{188}$ The Unlimited or "infinity" is the naturally consequent determination to arise after "limit" because, he argued, "it is necessary that every determining [principle] be of an opposed ratio to what it determines". 189 He does not explain how this rule would apply to lower formal intentions. For example, one might say that entitas determines infinity understood as non-entitas, and it may be that life would determine entitas as "not-life", but this is not clear from the text.

The "extremes of the universe", the gods and prime matter, share the common feature of being produced "by the primarily Good alone". 190 To explain the relation of prime matter to the subsequent determinative causality of prime infinitas, Berthold staged a confrontation between Plato and "others" (in this case, Dietrich of Freiberg) regarding the question of whether matter is "something one and simple through its essence". Opposing this thesis, Dietrich argued that matter is "many and essentially multiple" because of the plurality of its inherent capacities to receive different forms. ${ }^{191}$ To present Plato's alternative and correct position, Berthold took arguments from Ulrich of Strassburg stating that matter has a threefold being: (1) as simple in its substance, it is without composition and prior to "the first inchoation of form"; (2) as a "being of potency", it is subject to motion and change, insofar as it has "the inchoations of form", although it remains one by privation of any form in act, "and thus nothing yet is distinct in it"; (3) as "actual being", it is "determined by the act of form". ${ }^{192}$ This threefold distinction of matter, presented here as an exegesis of the Timaeus (which was not clearly stated in Ulrich) would correspond for Berthold to a precise sequence of causal influence, from (1) the Good, (2) to

188 Berthold of Moosburg, Expositio, 9oB, p. 155, l. 41 - p. 156, l. 77; 6oB, p. 172, 1. 66 - p. 173, l. 75, followed immediately by De divinis nominibus, 5.5 on the priority of per se esse relative to the other processions; 6oD, p. 173, 1. 98-107: Ubi notandum, quod hic [Dionysius] vocat 'totam' et 'per se ipsam virtutem' primam bonitatem intra ordinem unialem; $3_{3} \mathrm{~B}, \mathrm{p} .94, \mathrm{l}$. 7792. For the agreement of all three authorities, see Expositio, 139D, p. 34, l. 6o - p. 36, l. 117, where non ens in the Clavis is identified with the order of infinities.

189 Berthold of Moosburg, Expositio, 89B, p. 151, 1. 58-67.

190 Berthold of Moosburg, Expositio, 59C, p. 166, 1. 106-115.

191 Berthold of Moosburg, Expositio, 59C, p. 166, 1. 124 - p. 167, l. 148. Cf. Dietrich of Freiberg, De miscibilibus in mixto, ed. W. Wallace, in Opera omnia, vol. 4, 3.1-4, p. 32, l. 3 - p. 33 , l. 28.

192 Ulrich of Strassburg, De summo bono, lib. IV, tr. 2, c. 7 (2-6), p. 120, l. 18 - p. 124, l. 153. Berthold identified the inchoation of forms with Augustine's notion of the seminal reasons. See Expositio, 138 commentum, p. 31, 1. 246-248: secunda illustratio est infinitas ipsius materiae per incohationes omnium formarum in ea, quas quidam vocant rationes seminales, quas certum non esse eiusdem essentiae cum materia. 
power (virtus), ${ }^{193}$ and finally (3) being, for "prime matter, although it is a one when considered by itself, is yet unable to stand in the things of nature without [something] determining it". 194

As for the troublesome Proposition 159, Berthold maintained that it must be read in light of the Propositions 151-156, which concern "the properties of the gods, in comparison with one another and with their effects or orders". From this standpoint, Proposition 159 should be understood with reference to "a general property belonging to every order caused by the gods". ${ }^{195}$ In other words, he read the phrase "order of the gods" (ordo deorum) in the text as a subjective genitive, "the order that comes from the gods". In Berthold's view, this connected Proposition 159 both to Proposition 89 (the first result of Limit and the Unlimited is true Being), in that the order of being is clearly subordinate to the order of the primordial causes, and to Proposition 102, which stated that prime ens (the primordial cause of Being) bestows the mixture of Limit and the Unlimited.96

Berthold's commentary on Proposition 102 began by confronting an interpretation which, considering Proposition 89, would restrict the communication of Limit and Unlimited to true beings (enter entia) that alone participate "extensive infinity", either insofar as they are eternal in an atemporal sense or as perpetual through temporal succession. ${ }^{197}$ To avoid this result, Berthold introduced a distinction among the gods themselves. The primordial cause of being (prime ens) can be considered in two ways: as amethectum, ${ }^{198}$ it is

193 Berthold of Moosburg, Expositio, 57 G, p. 154, l. 224: materia prima, quae substantivatur per posse. Cf. Averroes, De substantia orbis, in Aristotelis opera cum Averrois commentariis, vol. 9 (Venezia: Junta, 1562-1574), c. 1, f. 3vL.

194 Berthold of Moosburg, Expositio, 89B, p. 151, l. 53-54. See also Expositio, 71D, p. 35, l. 128138: Verbi gratia: prime (prime] primae ed.) virtus determinat essentiam materiae primae, quae procedit a solo primo, per commentum 59, ad esse in potentia, puta ad virtutem receptivam formae, et sic essentia materiae subicitur virtuti; sed quia uterque effectus tam prime boni quam prime virtutis stat adhuc in quadam indeterminatione, ideo prime ens praesupponens effectum utriusque determinat et informat ipsum entitate, scilicet essentia formae; formae, inquam, talis, quae tantum dat esse.

195 Berthold of Moosburg, Expositio, 159, p. 189, 1. 5-7: [...] unam generalem proprietatem omnibus ordinibus a diis causatis convenientem. See also Expositio, 159D, p. 194, 1. 172-176.

196 Berthold of Moosburg, Expositio, 159F-G, p. 196, l. 229 - p. 197, l. 243.

197 Berthold of Moosburg, Expositio, 102A, p. 217, 1. 14-26.

198 William of Moerbeke inexplicably transliterated $\dot{\alpha} \mu \varepsilon \varepsilon \varepsilon \kappa \tau$ ¿ which he had translated elsewhere as imparticipatum (Propositions 23-24, 63 comm., 69 comm., 162 comm.). At Expositio, 99C, p. 20o, l. 69-81, Berthold inventively distinguished between imparticipatum and amethectum, arguing that the latter denotes a loftier kind of independent subsistence. That is, amethectum combines the senses of "the unparticipated", "the indivisible", and "the not-participating" (imparticipans). It is not only exalted above its effects, but it is "independent as such". In this sense, amethectum is equivalent 
"unbegotten"; 199 however, "as a unity included within the unifical order, it proceeds from two causes, namely, the primary cause and the auxiliary cause [concausa]". 200 Such a distinction within each primordial cause, as uncaused insofar as it is amethectum and yet dependent on the One, was a straightforward combination of Propositions 99 and 1oo. The gods are self-sufficient qua unities but are above self-sufficiency qua the super-plenitude of their distinctive intention. ${ }^{201}$ In one sense, this aligned with Berthold's characteristic distinction between the self-originating character of each god as a formal cause, coupled with its dependency on the Good as an efficient cause. However, we see here that Berthold has added another layer of complexity: the god of entitas (prime ens) depends both on the One and on prime infinitas as an "auxiliary cause". Berthold was careful to observe the difference between the more rarefied notion of the amethectum, which applies only to the gods, and the wider amplitude of the self-sufficient (antarkes). ${ }^{202}$ Yet this technical precision had to be abandoned to address the problem at hand, for Berthold finally conceded that prime ens "is, as it were, composed" from Limit and the Unlimited, which both "act in prime ente itself and with it". ${ }^{203}$ Only this can explain how all beings are recipients of the mixture of Limit and the Unlimited (according to Propositions 89 and 102). But the internal composition required to account for the serial order among the gods has compromised the pure simplicity of every god below prime infinitas. ${ }^{204}$

The conclusion drawn from Proposition 102 - that prime ens is "quasicomposite" because Limit and the Unlimited "act in prime ente itself and with it" - was used in Berthold's commentary on Proposition 159 to address

to the restricted senses of imparticipatum presented in Expositio, 23A, p. 112, l. 15 - p. 113, 1. 54 . However, at $161 \mathrm{~F}$, he was forced to admit that there is also a "less proper" sense of the term amethectum.

199 Cf. Berthold of Moosburg, Expositio, 23E, p. 117, l. 191-201, where Berthold presented this notion as the teaching of Dionysius.

200 Berthold of Moosburg, Expositio, 102B, p. 218, 1. 33-38: licet prime ens inquantum amethectum non sit ab alia causa, sed ingenitum per 99, tamen, inquantum est unitas quaedam intra ordinem unialem conclusa, procedit a duabus causis, scilicet principali et concausa. Principali, quod est prime unum, quod etiam directe est causa et totalis ipsius prime entis. Concausa, scilicet prima unitate intra ordinem, scilicet prime infinitate, quae est intermedia prime unius et prime entis per 92 in commento.

201 Berthold of Moosburg, Expositio, 99B, p. 199, l. 55-67; 100G, p. 208, l. 145-154.

202 Berthold of Moosburg, Expositio, 99A, p. 198, l.13 - p. 199, l. 41.

203 Berthold of Moosburg, Expositio, 102B, p. 218, 1. 43-48.

204 Cf. Berthold of Moosburg, Expositio, 23C, p. 115, l. 126-128: participatorum quaedam sunt simul, licet non secundum idem, participata, participantia et imparticipata, ut bonitates et unitates. 
"a controversy among the wise" concerning the origin of plurality and, more specifically, whether the dyad proceeds immediately from the One. From Thomas of York, who accepted their arguments, Berthold cited Avicebron, Gundissalinus, and Hermes on the dyad as the immediate product of the One and the root of plurality, which Avicebron and Gundissalinus identified as first matter and first form. ${ }^{205}$ Opposing such views were Dionysius, "whose authority prevails, since it is supported by infallible reason", and Boethius, who maintained that the angels and all things incorporeal are immaterial. Berthold resolved the controversy by distinguishing (or equivocating) between four different senses of the word "matter". ${ }^{206}$ (1) In "the strict sense", matter is what is "mixed with privation"; (2) in its "less proper sense", matter as it is found in the celestial bodies is identical with "the subject" of place and extension; (3) in its "wide sense", matter can mean anything that is subjected to act, such as rational souls and angels, which pass from intellection to non-intellection; (4) finally, in its "widest sense", matter can mean "an actual determining potency". The latter refers to the notion we have encountered already in section 4.1 in Berthold's account of "theological universality", according to which a more actual formal intention is determined or contracted by a more potential formal intention. In this fourth sense, one could say that "matter" is found in all beings beneath the gods as far as heavenly souls, in which there is a gradation of increasing formal determination and composition, but where the result nevertheless remains a single nature (unum in re). In this sense, then, everything proceeds from the dyad, which is "far better and more fittingly named the Limit and Unlimited". ${ }^{207}$ Nevertheless, when Berthold treated "the origin of these two principles" in themselves, he sought no compromise and rejected the arguments of Gundissalinus and Avicebron outright, using the principle from $5^{\mathrm{B}}$ that idem manens idem semper natum est facere idem, and the principle of procession by similitude. Since "nothing is the cause of its contrary", ${ }^{208}$ the One causes per se unities. Since two equally first principles

205 Berthold of Moosburg, Expositio, 159B, p. 191, l. 75 - p. 193, l. 137. Cf. Thomas of York, Sapientiale, lib. II, c. 11. On Thomas' hylomorphism, see D.E. Sharp, Franciscan Philosophy at Oxford in the Thirteenth Century (London: Oxford University Press, 1930), p. 63-64 and $83-85$.

206 Berthold of Moosburg, Expositio, 159C, p. 193, l. 139-167.

207 Berthold of Moosburg, Expositio, 159D-F, p. 194, l. 174 and p. 196, l. 229-233.

208 Berthold of Moosburg, Expositio, 159G, p. 197, 1. 249. This does not contradict his argument for the derivation of the Unlimited from the Limit in Expositio, 89B, p. 151, l. 58-59: omne determinans esse oppositae rationis ad illud, quod determinat, which referred to the emergence of new formal determinations that are unlike their cause owing to their distance or contraction of the cause's power. 
cannot emanate immediately and causally (causaliter) from the One, they are necessarily reduced to two principles or springs (scaturrigines): the prime unitas and the prima unitas. ${ }^{209}$

With the notion that infinity or prima unitas is the auxiliary cause (concausa) of the order of the gods, ${ }^{210}$ Berthold maintained that the order of unities is subject to the same rational laws as the rest of the invisible world: the highest member of any order acts as an auxiliary cause of its subordinate members. ${ }^{211}$ This determination of the causality of the One by prime virtus affects not only prime matter and prepares it for subsequent determinations, but "in some sense leaves a trace of its intention in the goodnesses following it". ${ }^{212}$ Nevertheless, Berthold did not overlook the more speculative interpretative possibility that his Eriugenian sources offered him: a model of the primordial causes or gods in which they are not so easily defined by linear structures. Commenting on Proposition 140, where Proclus alluded to the sympathy (compatientia) that is found in everything owing to the total presence of the higher principles in the lower, Berthold explained how each god not only leaves a vestige of its intention in the lower gods, as we would expect by now, but also that a lower god leaves a vestige of its intention in the order arising from a prior god. In other words, because prime intellectus leaves a vestige of its causal power in prime anima and prime natura, it "consequently" leaves a vestige "in the order

209 Berthold of Moosburg, Expositio, 159G, p. 197, 1. 263-264. Berthold frequently referred to the primordial causes as "springs", see $17 \mathrm{~A} ; 18 \mathrm{~B} ; 18 \mathrm{C} ; 99 \mathrm{~B} ; 100 \mathrm{D} ; 123 \mathrm{H} ; 131 \mathrm{E} ; 140 \mathrm{D} ; 143 \mathrm{D}$; $153 \mathrm{~B} ; 177 \mathrm{~F}$.

210 Berthold of Moosburg, Expositio, ${ }_{152}$ B-C, p. 141, l. 57 - p. 142, l. 81. An auxiliary cause is the summit (summitas) within a particular order and is itself subordinated to a primordial cause. See, for example, Expositio, 22B, p. 103, l. 180-186.

211 Berthold of Moosburg, Expositio, 159G, p. 198, 1. 278-286: immo [prime infinitas] relinquit vestigium suae principiationis etiam in ipsis diis. Sic ergo omnis ordo deorum, quem dii instituunt, est ex principiis primis fine et infinito formaliter et a primis principiis prime finitate et prime infinitate causaliter et originaliter, quorum unum est simpliciter primum, puta prime unum, aliud autem est secundario primum, a quo etiam tamquam a summo sui totus ordo deorum dependet; non iam proprie causaliter, sicut a primo simpliciter principio, sed suo modo, inquantum intra unum et eundem ordinem superius est concausa inferioris stans sub ordine principalis principii, quod principale per ipsum et cum ipso et in ipso sequentia producit.

212 Berthold of Moosburg, Expositio, 57G, p. 153, l. 209-214: Talis autem bonitas determinans et quasi informans causalitatem prime boni, ubi ipsa causalitas non valet in se ipsa subsistere, hoc est secundum gradum determinatae distantiae a primario boni actu, transcenso videlicet ordine bonitatum, quae sunt effectus simpliciter prime boni, incipit suam actionem in ordine virtutum, licet aliquale vestigium suae intentionis relinquat in sequentibus se bonitatibus. 
of infinities, true beings, and lives". ${ }^{213}$ This implies that the primordial causes in the Word act in concert. ${ }^{214}$ The enfolded order of the archetypical world is the basis for the unfolded sympathy of the cosmic order.

In one sense, of course, this example of prime intellectus was a convenient choice for this kind of mutual implication of intentions, inasmuch as it allowed Berthold to extrapolate Dietrich's notions of intellectus in actu per essentiam, essential causality, and the ontology of being according to species (ens secundum speciem) to higher principles that are not, strictly speaking, intellectual hypostases. But these passing acknowledgements of the relativity of a strictly linear model are consistent with Berthold's Eriugenian interpretation of Dionysius that we have noted already, where the strict divisions of reality according to the laws of proportion and analogy were resolved into a unified perspective that finds the first principle itself coursing through or being made in all things (ad omnia procedit et in omni fit). ${ }^{215}$ It was not by chance that, shortly after offering the example of prime intellectus leaving its vestige in the higher orders, Berthold cited the Clavis for the notion that God "descends from himself and creates himself in all things", and that the division of this providential act into a beginning, a middle, and an end, "are one in him, but are

213 Berthold of Moosburg, Expositio, 140D, p. 40, 1. 95-101: Sicut verbi gratia potentia prime intellectus non incipit ubi potentia prime boni vel prime infinitatis vel prime entis vel prime vitae, sed desursum, scilicet in ordine intellectuum, ubi primum manifeste apparet eius causalitas, licet aliquale vestigium suae intentionis relinquat et in prime anima et in prime natura et per consequens in ordine infinitatum, enter entium et vitarum. Et sicut dixi de prime intellectus potentiae incohatione, ita intelligendum est de aliorum deorum potentiis suo modo. This follows a citation of the Clavis physicae, c. 167 and 170, on the descent of all things from the Father of lights, and how "all things are from God and God is in all things [...], since from him and through him and in him all things are made".

214 On occasion Berthold would speak about the unique causality that belongs to each god: prime ens $(161 \mathrm{~A})$; prime vita $(53 \mathrm{~B}, 101 \mathrm{E})$; prime intellectus $(156 \mathrm{E}-\mathrm{F})$; prime anima $(129 \mathrm{D})$; prime natura $(20 \mathrm{~A}, 34 \mathrm{D}-\mathrm{F})$. Berthold's notion of a primordial cause of nature (prime natura) signaled a modification of Proclus who, in Proposition 21, carefully used "first" for the monadic One, Intellect and Soul, but "whole" for Nature. See M. Martijn, Proclus on Nature. Philosophy of Nature and its Methods in Proclus' Commentary on Plato's Timaeus (Leiden: Brill, 2010), p. 49. In 129D, Berthold identified the prime anima with the world soul (anima totius), which extends immaterially from the centre of the earth to the heights of heaven and directs particular souls to their proper places. He identified prime natura with Avicebron's notion of natura universalis (Fons vitae, lib. III, c. 45), the unified principle that brings together and sustains the composite parts of bodies because it acts upon "the universal body". All things that proceed from prime natura, according to Berthold's enigmatic statement, do so naturally (naturaliter). The world soul and natura universalis share the attributes of being unified principles whose activity is providential. Berthold of Moosburg, Expositio, 3A, p. 92, l. 14-19. 
diverse in the minds of those contemplating".216 The prayer at the end of the Prologus, we recall, was intended to lift the contemplator (theoricus) from the mode of dividedness to the unified vision of the divine light as the principle, the guide, and the goal of all things. For Berthold, then, the rational divisions of the order of natural providence according to the laws of proportionality, with the proliferation of separate substances they entailed, were meant to prepare the mind for this vision.

\section{Determination, Generation, and Light}

The intention of 'good' cannot subsist by itself. ${ }^{217}$

If Berthold relied on the distinction of efficient and formal causality to hold together the superabundant causality of the gods in the Word alongside their subordination to the One, he had to introduce a further level of differentiation to account for the constitution of principles in the essential order below "the thearchy". To this end, he adapted two interrelated doctrines from Dietrich of Freiberg to the framework of the Elementatio theologica: the ontological theory of beings existing according to species (entia secundum speciem), and the theory of the mode of causality that is constitutive of and exercised by them ("determination" or "information"). ${ }^{218}$

Berthold inherited directly from Dietrich of Freiberg the notion of "being according to species" or "being as such" (ens ut simpliciter). ${ }^{219}$ Dietrich had

216 Berthold of Moosburg, Expositio, 140E, p. 42, l. 151-158: super omnia Deus invisibilis et incorporalis et incorruptibilis potest a se ipso descendere et se ipsum in omnibus creare, 'ut sit Deus omnia in omnibus' et usque ad extrema rerum [...]. Deus totius universitatis conditae principium sit et medium et finis: principium, quia ab ipso procedunt omnia, medium, quia in ipso et per ipsum currunt omnia, finis, quia ipsum appetunt omnia, in quo quiescunt, quia nihil ultra quaerunt. Et haec tria in ipso unum sunt, in animis contemplantium diversa. Cf. Honorius Augustodunensis, Clavis physicae, c. 167, p. 132, 1. 7-10 and c. 171, p. 135, 1. 2-7. See also Expositio, 125D, p. 15o, l. 103-109, cited above at n. 183 , as well as the citation of the Clavis in n. 213, above.

217 Berthold of Moosburg, Expositio, 136E, p. 10, 1. 208: Intentio boni non potest ipsa subsistere.

218 On determinatio and informatio, see Albert the Great, De causis et processu universitatis a prima causa, lib. II, tr. 1, c. 17, p. 81, 1. 43-44 and lib. II, tr. 3, c. 13, p. 15o, 1. 44-63; Ulrich of Strassburg, De summo bono, lib. IV, tr. 2, c. 1 (3-4), p. 58, l. 28-46; Thomas Aquinas, Super Librum de causis Expositio, lect. 18, p. 104, 1. 1-17; Dietrich of Freiberg, De animatione caeli, 11.1-5, p. 22, l. 2 - p. 23, l. 28; id., De quiditatibus entium, 1.4, p. 99, l. 21-30.

219 On the synonymy of ens secundum speciem and ens ut simpliciter, see Dietrich of Freiberg, De intellectu et intelligibili, II.33.5, p. 172, 1. 22-28; id., Quaestio utrum substantia spiritualis sit composita ex materia et forma, ed. B. Mojsisch, in Opera omnia, vol. 3, II.20, p. 333, 
invented this notion as a way of accounting for the hierarchical subordination of separate substances within an essential cosmic order, in which the essence of every separate principle is identical with its operation. But the range of entities to which Dietrich applied it was more limited (intelligences and heavenly souls) than what we find in Berthold. Following the lead of the Elementatio, Berthold extended the range of ens secundum speciem upwards, into the order of infinities, and downwards, past the order of heavenly souls, to human nature as a species.

For both Dominicans, some kind of composition was required to explain the derivation or creatureliness of these separate substances without compromising the essential activity that was predicated upon their simplicity. The basic intuition that Dietrich and Berthold would not abandon was the assumption that the universe is an intrinsic unity (unum per se), and therefore it must be constituted out of an essential order, in which entities proceed from and return to their principles according to stable and necessary patterns. ${ }^{220}$ This essential order unfolds between the cosmological genera (maneries) of the One, the separate intelligences, as far as the heavenly souls and their bodies, which use the sublunary elements as instruments in order to produce their effects in the realm of becoming. This intrinsic order of the whole can be ensured only by the intrinsic and essential constitution of its parts. As Berthold put it, everything intrinsically related to something else in the order of essential causes is "a certain whole", but the relation of this whole to its own parts determines what place in the essential order it holds. ${ }^{221}$ The notion of ens secundum speciem was introduced to account for the intrinsic composition that distinguishes secondary causes from God without undermining the essential bonds of the order of natural providence..$^{22}$

1. 181-204. See also Berthold of Moosburg, Expositio, 2D, p. 87, l. 204-208: Si autem est unum, in quo est numerus secundum rem, hoc est dupliciter, quia vel facientia numerum sunt unum in esse vel plura. Si unum, tunc vel taliter unitum est ens ut simpliciter et secundum speciem tantum absque proprietate individuali vel est ens hoc et particulare et individuum.

220 Dietrich of Freiberg, De animatione caeli, 2.2-5.3, p. 13, l. 25 - p. 17, l. 30; id., De substantiis spiritualibus et corporibus futurae resurrectionis, 1.1-5.2, p. 303, l. 2 - p. 307, l. 17. For Berthold, see Expositio, 6B, p. 129, l. 75 - p. 13o, l. 126, as well as 33A, p. 214, l. 12 - p. 215, 1. 36. Cf. Flasch, "Einleitung" to Berthold of Moosburg, Expositio super Elementationem theologicam Procli. Prologus, Propositiones 1-13, p. xxxiii-xxxiv.

221 Berthold of Moosburg, Expositio, 66E-F, p. 5, l. 100 - p. 6, l. 13 .

222 Berthold of Moosburg, Expositio, 44A, p. 73, 1. 15-21: unaquaeque res est propter suam propriam operationem, ideo sola rei substantia seu essentia, si secundum se et absolute accipiatur, scilicet quantum ad solum esse, non sufficit intentioni naturae, nisi ipsa essentia sit operatio. [...] Absoluta enim essentia secundum se non habet rationem boni nec est de reali ordine universi, inquantum est unum totum perfectum specie et partibus, de cuius ordinis 
To explain this kind of composition, Dietrich looked to Aristotle(Metaphysics VII.10-11) for the distinction between formal parts (partes ante totum), which are simultaneously the principles of a simple form in the order of being and the parts of a definition in the order of knowing, and quantitative or qualitative parts (partes post totum), which are extraneous to the essential features of the thing. ${ }^{223}$ According to Aristotle, formal parts are "before the whole" insofar as they constitute the quiddity or definition of a thing and make it known in such a way that the whole can be said to depend on those parts. Parts "after the whole" have the nature of matter, meaning that they are the parts into which a thing is divided when it is viewed as a "this" and not in its universal definition. These material parts can be corporeal (flesh and bones, in the case of "this animal") or intelligible (the semicircle is part of "this circle"). ${ }^{224}$ Dietrich used these arguments to characterise the created separate substances in the order of natural providence. In his view, separate substances exist more like a species, ens secundum speciem (=ES), because they have only "parts before the whole". An Es is not an individual but a "singular". For an "individual" in the proper sense is what has "parts after the whole" or is an ens hoc $(=\mathrm{EH}) .225$

For Dietrich and for Berthold, the parts of a singular ES are principles. In an ES, these principles "retain their nature as principles", which explains why the essence, power, and operation of ES are one. ${ }^{226}$ That is, insofar as an essence does not require these extrinsic, accidental relations to realise its activity, it is incorruptible, its activity has no contrary, and as such the Es belongs to the

ratione est, ut una res fluat in aliam aliqua virtute activa. Cf. Dietrich of Freiberg, De intellectu et intelligibili, I.1.1, p. 137, l. 3-10, I.10.3, p. 143, l. 18-28; id., De accidentibus, 18.8, p. 79, l. 121 - p. 8o, l. 135 .

223 See especially Dietrich of Freiberg, De origine rerum praedicamentalium, 5.26, p. 187, 1. 221224, 5.62, p. 200, l. 650-662; id., De luce et eius origine, ed. R. Rehn, in Opera omnia, vol. 4, 10.1-12.2, p. 17, 1. 79 - p. 19, 1. 46; id., Quaestio utrum in Deo sit aliqua vis cognitiva inferior intellectu, 1.1 (6-7), p. 294, l. 36-48; id., Quaestio utrum substantia spiritualis sit composita ex materia et forma, II.25, p. 335, l. 252-269. See also id., De dotibus corporum gloriosorum, 2.3-4, p. 270, l. 12-23; id., De corporibus caelestibus quoad naturam eorum corporalem, ed. L. Sturlese, in Opera omnia, vol. 2, 3.2, p. 381, l. 98 - p. 382, l. 102; id., De accidentibus, 3.5, p. 57, l. 88-95; id., De quiditatibus entium, 7.5, p. 110, 1. 6o-71; id., De mensuris, 4.17, p. 231, l. 106-125; id., De magis et minus, 11.4, p. 55, 1. 64-68.

224 As Berthold explained at Expositio, 76K, p. 70, 1. 209 - p. 71, 1. 220, a substance, unlike an essence, has parts after the whole. These parts, when they are brought together by the form of the whole (forma totius), such as humanity (humanitas), have the mode of matter. Humanity considered in itself is an essence, but when it is determined in such and such parts (in has vel has partes), a substantial individual is constituted.

225 Suarez-Nani, Les anges et la philosophie, p. 56-73; Flasch, Dietrich von Freiberg, p. 314-319.

226 Berthold of Moosburg, Expositio, 34C, p. 229, l. 29o-311. 
essential structure of the cosmos. ${ }^{27}$ At the lower range of the essential order are heavenly souls. These, however, are called substantial rather than essential causes. Each heavenly soul is an EH because its activity partially depends on the heavenly body to which it is united.228 Finally, in the realm of becoming, there is no essential order. This is the domain of individuality and accidentality properly speaking, insofar as all spiritual or corporeal principles, whether angels, human individuals, or bodies, realise their activity in partial or total dependency upon accidental, extrinsic relations founded on quantity and quality. 229

These ontological conditions are related to distinct kinds of causality. EH come forth by generation, whereas Es come forth by "simple emanation", "determination", or "information". 230 What comes forth by generation passes from potency into act, and accordingly is first an EH before it is ES (which is accomplished by the universalising activity of the possible intellect). For example, nature produces a succession of individual horses, but the species "horse" is only reached through abstraction. As for what comes forth by determination, its "formal principles" are first Es by nature (prius natura). Certain entities, like heavenly souls or the agent intellects of human beings, are first ES and then, by a logical ordering, they are individuated and are E H. ${ }^{231}$

In one of the lengthiest discussions of this topic in the Expositio, Berthold contrasted ES and EH insofar as their principles are capable of union with one another (unibilia). ${ }^{232}$ That is, he proposed that we consider the opposing ways the constitutive principles of $\mathrm{ES}$ and $\mathrm{EH}$, insofar as they are principles, have simplicity, spirituality, and infinity. His argument proceeded from what is more known to us to what is unknown. "Imperfect" unitable principles, such as matter and form in a composite, are in "qualitative potentiality" and are, "so to speak, material" because their simplicity is inferior to the composite in which they must be united in order to exist in act. This union of matter and form in act has "spirituality" because they mutually conjoin in their

227 Dietrich of Freiberg, De intellectu et intelligibili, II.26.1-4, p. 164, l. 29 - p. 165, l. 57; id., De cognitione entium separatorum, 21.1-4, p. 185, l. 3o-6o.

228 Berthold of Moosburg, Expositio, 25C, p. 142, l. 166-172. Cf. Expositio, 44D; 5oC; 51A; 76D.

229 Dietrich of Freiberg, De animatione caeli, 8.2-3, p. 19, l. 6 - p. 2o, 1. 30, 15.1-2, p. 26, l. 38-53; id., De intellectu et intelligibili, III.21.2, p. 193, l. 103 - p. 194, l. 110.

230 Berthold of Moosburg, Expositio, 3A, p. 93, l. 37-38: Et tale fieri dicitur determinatio vel informatio, ut quidam dicunt, vel compositio. See also n. 218, above.

231 Berthold of Moosburg, Expositio, 3 B, p. 95, l. 116-121. Cf. Dietrich of Freiberg, De luce et eius origine, 10.1, p. 17, 1. 79-88.

232 For what follows, see Berthold of Moosburg, Expositio, 4 B, p. 105, l. 129 - p. 108, l. 242; 76D, p. $66,1.55-$ p. 67, l. 94 . 
essence (se mutuo penetrant penetratione essentiae), as is most evident in the "spirituality" of the simple and universal elements, which unite to form the four elements perceptible to the senses. Insofar as these individual principles, as principles, exist in potency, their "infinity" consists only in their indeterminacy. Accordingly, they cannot bring themselves to union in act, but require a higher agent (e.g., an artificer, a heavenly mover). The activity of this agent, in turn, presupposes these potential principles that it brings into substantial being by a process of generation. Since generation is preceded by motion and alteration, the principles themselves must be mutable and, for this reason, must exist first as individuals both in time and by nature before they are a species. Therefore, unlike the particular (angels; the human agent intellect prior to individuation) ${ }^{233}$ or the singular (ES), ${ }^{234}$ the individual constituted from such principles is measured by time; it comes to be and passes away due to the disproportion between its principles and the stable motion of the heavens.

As for the principles of unchangeable things or Es, Berthold asserted that they have a "simplicity" that is greater than any composite, whereas the simplicity of the principles of $\mathrm{EH}$ is subordinate to the composite they form. It follows from this that their "spirituality" is also greater, for what is simpler is capable of greater compenetration. Finally, unlike the principles of $\mathrm{EH}$, the "infinity" of the principles of Es consists in their actuality rather than potentiality. This actuality, however, still stands in relation to a higher active "efficient" principle. But rather than being brought into act by that agent, these lower principles actively limit, contract, or "determine" the power of the immediately higher cause and act upon the "elaborated" substrate that the higher cause has produced. In this way, we have a process of "determination" that occurs by an order of nature and not by a temporal order (unlike "generation"); that is, determination unfolds by simple emanation into being (per simplicem emanationem in esse). Every principle that comes forth by determination, even

233 Berthold of Moosburg, Expositio, ${ }_{51}$ C, p. 115, l. 98 - p. 116, l. 111.

234 Berthold of Moosburg, Expositio, 84B, p. 128, l. 20 - p. 129, l. 44. An individual is corporeal and has quantitative partes post totum. A "particular" has qualitative partes post totum, and through them it is determined within "the most specific species", and yet it remains "one in being" and is not numbered by its parts. The "singular" subsists "singularly per se", having partes ante totum that retain their nature as principles. In Expositio, 10B, p. 180, 1. 122-132, we read that the members of the order of antarkia (ES), whose essence is identical with their power and operation, differ from one another specifically (specifice), until we reach heavenly souls, which are "individuated" by their operation. In a hierarchia comprised of angels, the substance, power, and operation of each member differ, and each member is a particular (particularis). 
if it is limited or contracted, is nevertheless identical with its operation. ${ }^{235}$ As Berthold put it in a succinct and remarkable turn of phrase, their possibility is their existence (in eis sit idem posse et esse). ${ }^{236}$ We might say that, for Berthold, the domain of Es, from the order of infinities to heavenly souls (prior to individuation) and to human nature as a species, corresponds to the contents of "the archetypical world" and is, in some sense, nothing else than its unfolding from the divine Word. ${ }^{237}$

For Berthold, this process of determination could only be understood if one adopted a Platonic rather than Aristotelian perspective on universality. This is most apparent in his commentary on Proposition 74 ("Every species is a certain whole, for it subsists from many [parts], each of which complete the species, but not every whole is a species"). ${ }^{238}$ Following Eustratius, he held that there are fundamentally only two kinds of species: one is the result of abstraction, the other is separate by nature. ${ }^{239}$ The first is constituted by the actualised possible intellect from the parts of the form. ${ }^{240}$ It is through this process that natural beings pass from the state of EH to ES, since the possible intellect is what makes the universality in such things (intellectus agit universalitatem in rebus). The second kind of species exists in rerum natura apart from any activity of our intellect. Berthold argued that since the participant (participans) exists in reality, so must the greater entity in which it participates (participatum): "many human beings are one human being by participation in the species". Every species of the second kind, then, is an ES belonging to essential order of the cosmos. Some things belong to the intrinsic order of the universe only as species (ES), while others do firstly as species, and secondly as individuals, as is the case for angels and human souls. For the

235 See Berthold's analysis of the seven regulae from Boethius' De hebdomadibus in Expositio, 2A, p. 83, l. 54 - p. 84, l. 93.

236 Berthold of Moosburg, Expositio, 4B, p. 108, 1. 238.

237 Berthold of Moosburg, Expositio, Prol. 10, p. 16, l. 364 - p. 17, l. 385. A comparison can be made on this point with Henry of Ghent, who held that the number of creaturely essences and that of the divine ideas were equal and finite. See P. Porro, "Ponere statum. Idee divine, perfezioni creaturali e ordine del mondo in Enrico di Gand", in Mediaevalia 3(1993), p. 109-159.

238 Proclus, Elementatio theologica, prop. 74, p. 39, l. 1-3: Omnis quidem species totum quoddam est: ex pluribus enim subsistit, quorum unumquodque complet speciem; non omne autem totum species.

239 Berthold of Moosburg, Expositio, 74A-C, p. 51, l. 44 - p. 55, l. 185. See also Expositio, 67C, p. 9, l. 6 o - p. 12, l. 134; 176D, p. 165, l. 242-253; 177I, p. 183, l. 335 - p. 184, l. 349.

240 See Dietrich of Freiberg, De origine rerum praedicamentalium, 5.26-33, p. 187, 1. 209 p. 19o, 1. 311. See also Dietrich of Freiberg, De visione beatifica, 3.2.9.7 (3), p. 98, l. 11-18; id., De intellectu et intelligibili, III.36.1-III.37.5, p. 208, 1. 25 - p. 209, l. 7 O. 
latter group, the species is "more truly and more really in the nature of things than its individuals". 241

Berthold corroborated this argument about the two kinds of species with Anselm's famous denunciation of "the heretical dialecticians" who say that universals are only "vocal sounds", and who therefore suppose that colour is nothing other than the body in which it inheres and that wisdom is nothing other than the soul of the person in whom it is found. ${ }^{242}$ According to Anselm, such confusions arise when reason is covered over with bodily imaginings (in imaginationibus corporalibus obvoluta), a judgement that Berthold shared based on his own interpretation of the De mystica theologia of Dionysius as a guide to the discord over universals. For Anselm, the heretical consequences of this contemplative failure are felt in the domains of Trinitarian theology and Christology. Without real universals, Anselm contended, one cannot even begin to understand how three persons in the Trinity are one God, or how it was that Christ assumed human nature and not a human person. Berthold's only addition to these points was a lengthy citation from the Clavis physicae, that explained how humanity (humanitas) is both simple in its cause and "more than infinite" in individuals, as an example of a Platonic species.

This theory of the two kinds of species was closely related to Berthold's theory of form, which also assumed the ontology of ES and EH, but proposed a greater continuity between the two domains. As Sylvain Roudaut has observed in a recent synthesis, Berthold's doctrine of form and formal causality expanded the application of these terms far beyond their more limited place in Proclus' Elementatio theologica, which in Proposition 74 located forms at the level of intellect and thus subordinated them to the levels of being and wholeness. ${ }^{243}$ Berthold was more influenced in this regard by Albert the Great, who distinguished between separate or forming form (forma formans) and immanent or informing form (forma informans). ${ }^{244}$ At other times he followed Ulrich of Strassburg, who delineated the grades of form from God to accidental, inanimate form. ${ }^{245}$ With Albert, Berthold presented the ranks of animate forms in terms of their gradual approximation of the first mover and its capacity to

241 See Suarez-Nani, Les anges et la philosophie, p. 6o, for an illustrative comparison of Thomas Aquinas and Dietrich of Freiberg on the subordination of individuals to species in the cosmic order.

242 Berthold of Moosburg, Expositio, 74C, p. 55, l. 186 - p. 56, l. 227.

243 S. Roudaut, "Founding a Metaphysics of Light in Proclus' Universe. Berthold of Moosburg's Theory of Forms", forthcoming.

244 Berthold of Moosburg, Expositio, 41C, p. 49, l. 73 - p. 51, l. 148.

245 Berthold of Moosburg, Expositio, 112D, p. 27, l. 73 - p. 3o, l. 165. 
constitute and govern an articulated whole. ${ }^{246}$ Heavenly souls, followed by human souls, are the highest rank of forma informans, since they are partially related to the bodies they move. A forma formans, by contrast, subsists in itself and remains outside what it determines (foris manens). These include all Es beneath the gods as far as intellectual hypostases, which are "formed" by determinatio, in that the subject elaborated by the higher principle is "informed" or determined by lower, primordial "forms" or causes.

In his account of determinatio, Berthold combined Dietrich of Freiberg's theory of causality with the doctrine of flux (fluxus) developed by Albert the Great (De causis et processu universitatis I.4) and Ulrich of Strassburg (De summo bono IV.1.5), who was his preferred source on the theory of fluxus. ${ }^{247}$ Berthold discussed fluxus extensively in his commentary on Proposition 18 ("Everything deriving being to others is primarily that, which communicates the derivation to the recipients"), ${ }^{248}$ where William of Moerbeke's translation of Xopnyouv as derivere brought Proclus' text directly into the semantic field of the metaphysics of flow. Berthold's definition of derivation ("derivation is both a simple and continuous causal emanation, preserving the identity of essence of the flowing form in the entire flow") depended on Ulrich's treatment of fluxus. ${ }^{249}$ As Berthold explained it, "derivation" conserves the identity of form or intention between the cause and effect (unlike equivocal causality), while remaining unaffected by its action (unlike univocal causality) and, unlike causes that are principles (principatio), it does not enter the being (esse) of what is derived.

246 Berthold of Moosburg, Expositio, 205A-C, p. 209, l. 12 - p. 212, l. 121.

247 De Libera, Métaphysique et noétique, p. 190-191, has explained how Ulrich's modifications of Albert's doctrine of flux anticipated the doctrine of essential causality articulated by Dietrich and Berthold. With Albert, Ulrich affirmed (1) that form is what flows, because the origin of fluxus is the form of the light of the first universally active Intellect; (2) form is said to flow insofar as it goes out from the first principle, and not insofar as it comes from a material potency; (3) the origin of fluxus is the Giver of Form (dator formarum), since anything that bestows form on anything else does so by virtue of the abundance of this source. To these views, Ulrich added (4) what flows is essentially identical and differs only in being; (5) the differentiation of being comes from the diverse realities into which the form flows; (6) this differentiation is comparable to the multiplication of a genus in its species, which does not multiply the essence of the genus but only its being. Dietrich's synthesis of these ideas with those of Proclus, according to De Libera (p. 204), allowed him to elaborate the doctrine of essential causality in its definitive form.

248 Proclus, Elementatio theologica, prop. 18, p. 12, 1. 1-2: Omne derivans esse aliis ipsum prime est hoc quod tradit recipientibus derivationem.

249 Berthold of Moosburg, Expositio, 18C, p. 5o, l. 245-246: derivatio est emanatio causalis simplex et continua conservans identitatem essentiae formae fluentis in toto fluxu. 
Following Albert and Ulrich, Berthold took one of his preferred examples of fluxus from the activity of an artificer. The art in the artificer's mind "flows" through the body's limbs and its tools, and through these the form is gradually determined until it is realised in the artefact. ${ }^{250}$ The same form is found in the art and in the artefact (idem essentia) and differs only in the mode of its existence (secundum aliud esse). To break through the materiality of the metaphor to a more adequate understanding of the process of determinatio, one should conceive the art itself as capable of producing artifacts by its simple intellectual light, without the need of bodily limbs, instruments, and matter. ${ }^{251}$ To this effect, in Proposition 18, Berthold used the example of the sun. For the sake of argument, he noted, we might suppose that the sun is an essential cause (though in fact it is a heavenly body that acts as an instrument of an intellectual principle). He then proposed we make a twofold comparison between the sun and its effects. (1) Compared with the sun's essence as such, the effect is identical with the cause, for the sun not only contains the effect in its power, but precontains (praehabet) its effect in a nobler and more eminent mode than the effect exists in itself. Considered simply as essence, the sun is "identical with all its gifts", indeed "is itself its gift", but in a more eminent mode. However, (2) compared with "the essential modes or properties of the sun", in which the substance of the sun is founded (fundatur), such as "incorruptibility, luminosity, moving in this particular way", the effect is counted as something distinct from the sun in both being and essence. ${ }^{252}$ Only (1) where there is an identity of essence within a diversity of being or nature, can we speak of derivation. The second comparison (2) falls within the domain of causality in the strict sense, in which effects differ from causes in being and in essence. ${ }^{253}$ Dietrich of Freiberg, who had inspired this distinction of derivation and causality, explained that the difference in being and in essence in the second comparison means that the efficient power of the heavens does not retain its "proper intelligibility" when it is found in its effect, ${ }^{254}$ because the stable disposition of celestial power is received only imperfectly in sublunary matter.

$25^{\circ}$ Albert the Great, De causis et processu universitatis a prima causa, lib. I, tr. 4, c. 6, p. 49, 1. 8 o - p. 5o, l. 11; Ulrich of Strassburg, De summo bono, lib. IV, tr. 1, c. 5 (2), p. 27, l. 16 - p. 28 , 1. 27. Albert also compared the ebullitio of the sun and of the first cause to the practical intellect in De animalibus, lib. Xx, tr. 2, c. 1, p. 1307, l. 11 - p. 1308, l. 30.

251 Berthold of Moosburg, Expositio, 174A, p. 137, l. 39-45.

252 Berthold of Moosburg, Expositio, 18D, p. 52, l. 300 - p. 53, l. 323.

253 Berthold of Moosburg, Expositio, 18D, p. 53, l. 324-341. We should assume that Berthold took the second comparison as the statement of the fact.

254 Dietrich of Freiberg, De intellectu et intelligibili, III.21.1-2, p. 193, l. $100-$ p. 194, l. 110. 
(1) The first comparison brings us directly into the domain of determination and the kind of causality that characterises Es. According to Berthold, there are three kinds of determination. ${ }^{255}$ (1a) In a logical consideration, the potential genus is determined into act by the species through the differentia; ( $1 \mathrm{~b})$ among material beings, a potency for form is determined in the act of form; (1c) in derivation, the more actual is determined by the more potential. In all three cases, the determinable, "existing in the determinate", maintains its proper essence, intention, and property, and is numbered only according to being. While it is clear what the subject of determination is in (1a) and ( $1 b$ ), either the genus or the material potential for form, what is the subject of the (1c) third kind determination, which evidently was most important for Berthold? The answer to this is not forthcoming in Proposition 18 and requires us to look elsewhere in the Expositio.

According to Proposition 64, the One immediately produces two kinds of unities: those that subsist in themselves (the gods), and those that subsist in another. The members of the latter group are the subject of either determination or generation - determination in the case of Es (immutable species, forming forms, or true forms), and generation in the case of $\mathrm{EH}$ (informing forms, and the images of true forms). In a remarkable passage, Berthold explained how, in every es below the gods, we find "unities" that are unable to subsist by themselves (non valens subsistere) as they are in their immediate relation to the One, owing to their "distance" in the procession that unfolds necessarily according to an essential order. ${ }^{256}$ These unities are nothing else than the "unities exalted above the nature of the mind" described by Dionysius or, as Proclus called them, "vestiges of the One" (the expression unum animae would be inappropriate here for the numerous principles prior to souls). These unities are illuminated by principles subordinate to the One, which strengthens them to

255 Berthold of Moosburg, Expositio, 18D, p. 53, l. 342-354. See also Expositio, 3E, p. 97, l. 206 p. 98, l. 247. At Expositio, 167E, p. 65, l. 210-220, following Dietrich, Berthold distinguished between the principles of the essence of an intellectus in actu per essentiam, and the parts of the form that are gathered in the definition.

256 Berthold of Moosburg, Expositio, 12A, p. 198, 1. 39-67: In separatis [...] similiter aliqua de praedictis causarum generibus, licet secundum aliam rationem a praefatis, inveniuntur. [...] Causa autem subiectiva et quasi materialis accipitur penes intentionem causalioris principii, quae, cum in se et per se non possit subsistere propter distantiam sui a prime sua causa, per aliam intentionem proximi subordinati producentis quasi informatur, determinatur et singularizatur. On the role of determination in strengthening these vestiges that cannot subsist on their own, see also Expositio, ${ }_{3} \mathrm{E}, 3 \mathrm{OA}, 41 \mathrm{C}, 59 \mathrm{D}, 64 \mathrm{~B}, 65 \mathrm{~F}, 90 \mathrm{C}, 137 \mathrm{~F}$, and $138 \mathrm{~B}$. The role of "proximity" and "distance" in any essential order was emphasised already in ${ }_{1} \mathrm{C}$, after Berthold spoke of the ecstasy of divine love that leads God to create the universe. 
subsist - this is what occurs through determination. ${ }^{257} \mathrm{~A}$ lower god determines with its own irradiation the immaterial substrate already elaborated by one or more prior principles. At the root of all of these substrates among spiritual substances is the vestigium unius. ${ }^{258}$ But, Berthold stated clearly, at least in the case of the determination of an Es, "the subjective cause" of determination is still more actual than the subsequent determination it receives. ${ }^{259}$ This is how the Es enumerated in the table at $62 \mathrm{C}$ arise.

We may locate this account of the determinatio or derivatio of ES within a larger framework of the modes of procession that Berthold systematised from Dietrich of Freiberg in his commentary on Proposition 29 ("Every procession is made through the likeness of the secondaries to the primaries"). ${ }^{260}$ Following Dietrich, Berthold made a distinction between what proceeds (1) from reason (a ratione) and (2) what proceeds according to reason (secundum rationem). ${ }^{261}$ (1) When something proceeds "from reason", the reason itself is the productive principle, such that no other power is required to bring about the procession; it would be as if the art of playing the lute were to play the lute by itself. Dietrich identified this as the mode according to which "the images of God", that is, every intellectus in actu per essentiam from the separate substances to the human agent intellect, proceed insofar as they are imagines Dei. By contrast, (2) to proceed "according to reason" means that the reason is in the producer who has an additional power (virtus elicitiva) that brings about the production.

257 Berthold of Moosburg, Expositio, 162B, p. 17, l. 33-46: Et tales unitates sunt divinissima, quae sunt in essentiis entium, vitarum, intellectuum et ceterorum, et sunt supposita traditionibus aliorum deorum, quorum illustrationes pertingunt ad ipsa sicut a prime uno elaborata, et sunt susceptiva omnis processus, qui est ab ipsis diis, et praecedunt simpliciter omnes donationes ipsorum deorum per 71. Hae enim sunt illae unitates, de quibus aliqualiter dictum est super 135, et sunt in nobis excedentes secundum Dionysium 7 cap. De divinis nominibus 'mentis naturam', et vocantur unitates superexaltatae. Sicut igitur in nobis sunt illud intimum et supremum, quod Deus in natura nostra plantavit, quod etiam est 'vestigium' et illustratio solius prime 'unius', quod determinatur ulterius aliis illustrationibus, puta virtutis, entitatis, vitae, intellectualitatis et ceteris, ita est proportionaliter in omnibus enter entibus supra hominem et citra deos, quod videlicet solius prime unius, super quam fundant aliae causae primordiales suas illustrationes secundum ordinem totalitatis earum.

258 Berthold of Moosburg, Expositio, 4B, p. 107, 1. 231-234.

259 Berthold of Moosburg, Expositio, 41E, p. 51, l. 169-179; 71E-F, p. 36, l. 140-153; 98B, p. 193, 1. 85-86.

26o Proclus, Elementatio theologica, prop. 29, p. 19, 1. 1-2: Omnis processus per similitudinem secundorum ad prima efficitur.

261 For what follows, see Expositio, 29B-C, p. 184, l. 78 - p. 185, l. 127, which relies on Dietrich of Freiberg, De intellectu et intelligibili, II.32.1-II.36.3, p. 170, l. 104 - p. 175, 1. 115. For a fuller account of Dietrich's position, see also De visione beatifica, 1.2.1.1.1-1.2.1.1.5, p. 37, 1. 10 p. 41, 1. 69. 
What proceeds in this way are the determinate species of things (e.g., the species "horse") that have (2a) an exemplary form (forma exemplaris) in God. EH properly speaking also proceed (2) "according to reason", but in addition to requiring (2a) the specific determination that comes from the exemplary form, they have a further determination that God knows in their (2b) ideal form (forma idealis). Es, however, proceed both (1) as an image and (2a) according to an exemplary form. This accounts for their self-subsistent "singularity", which is simpler than "individuality", but which is nevertheless determinate because it corresponds to an exemplary form in the divine mind. According to Dietrich, their mode of procession as (1) images predominates over (2a) that determinacy, since each intellectus in actu per essentiam is "a likeness of the totality of being" because it understands all being as such, and not just of some part of being. For Berthold, who was able to refine Dietrich's position on this point, the true realisation of $(1)$ is found in the gods, whereas every Es below the gods as far as the separate intelligences proceed according to both (1) and (2a). Berthold also clarified that, in the case of heavenly souls and human beings, we must be dealing with some combination of (1), (2a), and (2b), since their relation to body makes them individuals, even though their highest part is an essentially active intellectual principle. Finally, Berthold noted, generable and corruptible things proceed only according to ( $2 \mathrm{a})$ an exemplary form and $(2 \mathrm{~b})$ an ideal form.

Berthold elsewhere made similar refinements of Dietrich's order of essential causes or intellectus in actu per essentiam. ${ }^{262}$ Dietrich had elaborated a theory of three kinds of causes: (i) essential, (ii) substantial, (iii) and accidental causes. In this model, God and Es are essential causes. An essential cause is an essence that produces another essence through a simple outflowing (per simplicem defluxum), without motion or change. The only difference between God's activity and that of the Es from this point of view corresponds to the amplitude or determination of the causal activity - that is, how many formal intentions are presupposed by the Es. Berthold was not satisfied with this generic description of essential causality and thus subdivided it into three levels: (ia) the unbounded causality of the Good; (ib) the limited, but relatively unbounded causality of the gods; (ic) and the determinate and contracted causality of the Es. Each god produces an entire cosmic series, whose intention is equally present to all, but this is contracted within the order by the auxiliary cause (concausa) at the order's summit, which makes each member of that

262 Berthold of Moosburg, Expositio, 7 B, p. 146, l. 265 - p. 151, l. 447, supplemented with Expositio, 51A, p. 113, l. 11 - p. 114, l. 33 . 
order a singular. ${ }^{263}$ From here, Berthold simply summarised Dietrich's account of substantial and accidental causes. In a substance, the essence is contracted (contrahitur) to being either in potency or in act, and with this comes all the extraneous instruments and attributes that are needed for the substance to be realised in act. In this way, the substance is "contracted further to individuals" or EH possessing "parts after the whole". A thing can vary in its substance, insofar as it passes from an imperfect to a perfect state, but it cannot vary in its essence. Heavenly souls with their bodies are the paradigm of substantial causes. They presuppose the essences of generable things that have been constituted by ES and draw them out of potency into actuality through their motions and with celestial heat and light, as far as the imperfection of sublunary matter will allow. ${ }^{264}$ Finally, accidental causes presuppose substance, and act upon the extrinsic features of the thing.

As we descend from the realm of being (ES) into becoming (EH) we see that the entire procession, from God to the material world, is related in Berthold's understanding of formal perfections or "intentions". The One existing according to cause produces only "ones", either according to essence or participation, which are immediately related to it. Each entity in its ground, insofar as it is one or good, is immediately dependent upon the creative causality of the One. Each of the six gods originates from itself a unique formal intention reflecting its rank within the order of primordial causes. We have seen how this model forced Berthold to admit both that a higher god leaves a vestige of its formal intention in the lower god and that a lower god leaves a vestige of its formal intention in the order arising from the higher gods. This reminds us that the gods, despite falling into a rank when viewed from their effects, remain ineffably in the divine Word insofar as they are substantial goods that are "made" and not "created", and that creation proceeds from God according to the modalities latent in the archetypical world. ${ }^{265}$

A series arises from each primordial cause according to "a causal procession", which Berthold defined as "an emanation of a nature from another nature that preserves the natural distinction within an intentional identity".266 This description of the intelligible unity of a causal order as "intentional" came from Dietrich of Freiberg, who had used it relative to Propositions 21 and 97 of

263 Compare Berthold of Moosburg, Expositio, 7 B, p. 147, l. 306-316, with Expositio, 38B, p. 28, 1. 49-51.

264 Berthold of Moosburg, Expositio, 25C, p. 142, l. 177-186; 72C, p. 39, l. 53 - p. 40, l. 82.

265 Berthold of Moosburg, Expositio, Prol. 9, p. 14, l. 300 - p. 15, l. 32 .

266 Berthold of Moosburg, Expositio, 29A, p. 183, 1. 54-55: emanatio naturae a natura salvans distinctionem naturalem in identitate intentionali. 
the Elementatio theologica. ${ }^{267}$ Dietrich argued that the unity of the universe derives from the fact that "the essence of the first principle" is diffused "intentionally" by its causal power. ${ }^{268}$ That is, the same essence is found in the effects of the first principle, but it exists in each according to the recipient's mode of being.

Berthold included these passages from Dietrich in his commentaries on Propositions 21 and $97,{ }^{269}$ but he only explained exactly what he understood by the term "intention" in Proposition $71 .{ }^{270}$ There Proclus had outlined the important principle that each lower cause presupposes the causal power of the higher cause as well as the substrate that the higher cause has elaborated. Berthold's discussion of the meanings of intentio, it must be noted, was not prompted by the presence of the term in the Elementatio, but rather by Proclus' use of the word "illuminations" ( $\dot{\varepsilon} \lambda \lambda \dot{\alpha} \mu \psi \varepsilon ı \varsigma$, illustrationes) to describe the causality exercised by the gods. ${ }^{271}$ In one sense, Berthold explained, "intention" can refer to what exists indifferently in the soul or outside the soul. Such intentions are either "the six transcendentals according to Aristotle" (ens, res, aliquid, unum, verum, bonum), which "are identical in reality, but distinct in reason", or are the parts of a definition (genus, differentia, and species). In another sense, "an intention is distinguished from the thing in the soul", and this again has two senses. If it "implies an imperfection", we say that "the existence colour in the [transparent] medium" is intentional (intentionale), which presumably means that the illuminative power of colour is weaker or imperfect compared to that of light. If "intention" denotes something that brings about a perfection, then it refers to the formal intentions of "good", "infinite", "being", and so on, as they exist in the primordial causes or, in a more contracted way, in the

267 Dietrich of Freiberg, De cognitione entium separatorum, 74.2-5, p. 237, 1. 99-118.

268 Dietrich of Freiberg, De cognitione entium separatorum, 79.3, p. 242, l. 36-41: De ista autem unitate seu una intentione, de qua tot et talia dicta sunt, ut apparet intuenti, potest expressius dici sic, videlicet quod ipsa est essentia primi principii in se ipsa existens secundum proprietatem substantiae suae, sed intentionaliter secundum virtutem suam diffusa per rerum universitatem, quo tota rerum universitas non solum ab ipso tamquam a causali primo principio, verum etiam inter se secundum partes suas causaliter dependeat.

269 Berthold of Moosburg, Expositio, 21I, p. 91, l. 531-539; 97B, p. 186, l. 42-53.

270 Proclus, Elementatio theologica, prop. 71, p. 38, l. 1-9: Omnia que in primordialibus causis totaliorem et superiorem ordinem habentia in effectibus secundum eas que ab ipsis illustrationes supposita aliqualiter fiunt partialiorum traditionibus; et que quidem a superioribus illustrationes suscipiunt eos qui a secundis processus, ille autem in hiis locantur; et ita precedunt participationes alie alias, et illustrationes alie super alias desuper ad idem pertingunt subiectum, totalioribus preoperantibus, partialioribus autem super illorum operationes sui ipsorum traditiones elargientibus participantibus.

271 Berthold of Moosburg, Expositio, 71A, p. 32, l. 21 - p. 33, l. 47. 
higher members of their orders and in their participants. Berthold then went on to contrast the Platonic and Aristotelian understandings of what it means to be a "common" intention. For Aristotle, it had to do with the universality of predication or signification. For Plato, intentions were understood to be common in reality (intentiones communes secundum rem), and it was of course this approach that Proclus adopted in Proposition $71 .{ }^{272}$ These contrasts are familiar enough. What was new in Berthold's account was the close association of the intentio extra animam, the irradiation or illumination of the primordial causes, with the natural phenomena of light and colour.

The top and bottom of Berthold's cosmology are connected seamlessly in his theory of the diffusion of light. It is here that we come full circle and understand why the metaphor of the sun served so well to illustrate the ecstatic creative activity of divine love. This went beyond a commonplace association. In Propositions $36,37,125$, and 143 , we find that Berthold not only used light as a metaphor to describe the procession and conversion of all things. He understood the dynamics of these orders by extrapolating from specific principles concerning the nature and diffusion physical light that had been propounded by the perspectivists: Alhazen (De aspectibus, translated c. 1200), Roger Bacon (De multiplicatione specierum and Perspectiva, early and mid-126os), Witelo (Perspectiva, mid-127os), and John Peckham (Perspectiva communis, c. 1280). ${ }^{273}$ Berthold may have known the works of all these 13th-century perspectivists. He was certainly familiar with Alhazen's De aspectibus ${ }^{274}$ and Dietrich of Freiberg's De iride et radialibus impressionibus (after 1304). ${ }^{275}$

272 Berthold of Moosburg, Expositio, 71D, p. 33, l. 51-62.

273 This natural scientific dimension of Berthold's metaphysics been recognised since Barbara Faës de Mottoni's analysis of Propositions 36 and 37; see B. Faës de Mottoni, "Il problema della luce nel Commento di Bertoldo di Moosburg all'Elementatio theologica di Proclo", in Studi medievali 16(1975), p. 325-352. Alain de Libera concluded his fundamental study of the German Dominicans with Berthold's theory of light as a way of summarising the characteristic motifs of that intellectual culture; see De Libera, La mystique rhénane, p. 410-423. Most recently, Sylvain Roudaut has examined Berthold's synthesis of Dietrich of Freiberg's theory of perfectional form and his incorporation of other sources like Avicebron and Adam Pulchrae Mulieris, and has demonstrated that we can indeed speak of "a metaphysics of light" in the Expositio; see Roudaut, "Founding a Metaphysics of Light", forthcoming.

274 Berthold of Moosburg, Expositio, 143O, p. 72, 1. 435 - p. 73, 1. 46 o.

275 We may recall here the glosses on Aristotle's Meteorology attributed to Berthold that appear in the margins of Dietrich's De iride (in Ms Basel, Universitätsbibliothek, F.IV.30, f. 56v-

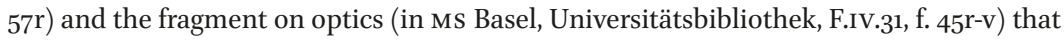
was copied by the same scribe responsible for Berthold's text of Macrobius' In Somnium Scipionis and the fragment of Proclus' De decem dubitationibus circa providentiam. The 
Berthold's discussions of light in Propositions 125 and 143 were guided by his standard procedure of basing his comments on the precise terminology used by Proclus (125: emicare; 143: a divino lumine). ${ }^{276}$ These passages, however, should be read alongside his more systematic exposition of a theory of light in his commentaries on Proposition 36 ("Of all things that are multiplied through procession, the primaries are more perfect than the secondaries, and the secondaries are more perfect than those that come after them, and so on in the same way") and Proposition 37 ("Of all things subsisting through conversion, the primaries are more imperfect than the secondaries, and the secondaries are more imperfect than those that follow them, but the last things are the most perfect"). 277 These commentaries marked a flagrant departure from his exegetical method, since in Propositions 36 and 37 Proclus had made no reference to light or illumination. Berthold's decision to give a summary of the entire metaphysics of the Elementatio theologica, as it can be recapitulated in the pattern of procession and return, through a theory of light allows us to glimpse some of the deepest assumptions he brought to the text. Perhaps the only comparable passage in this respect was Berthold's presentation of the astrologer as a paradigmatic example of the human vocation to be a nexus Dei et mundi, mediating between the stable realm of being and the changeable realm of becoming, according to the Proclean notion of "ruling the world with the gods". 278 Both passages not only clarify Berthold's interpretation of the philosophical principles of the Elementatio as a representative text of the Platonic tradition, but also hint at his broader assumptions about how this divine science was continuous with the philosophy of nature.

Berthold's approach to Propositions 36 and 37 moved across three levels of light (the physical, the intellectual, and the supersubstantial). For both commentaries, even though Proposition 36 begins, so to speak, "from above" and Proposition 37 "from below", Berthold started out from the laws of physical light, and from there moved to treat intellectual light and, finally, supersubstantial light. His preferred authorities for describing the level of intellectual

glosses and the fragment on optics are edited in Sturlese, "Note su Bertoldo di Moosburg O.P.", p. 249-256.

276 Proclus, Elementatio theologica, prop. 125, p. 63, l. 1-4, cited in n. 42, above; prop. 143, p. 71, 1. 1-3: Omnia deteriora presentia deorum subsistunt; et si ydoneum sit participans, omne quidem quod alienum a divino lumine fit, illustratur autem omne subito a diis.

277 Proclus, Elementatio theologica, prop. 36, p. 22, l. 1-3: Omnium eorum que secundum processum multiplicantur prima sunt perfectiora secundis et secunda hiis que post ipsa, et consequenter eodem modo; prop. 37, p. 23, l. 1-3: Omnium secundum conversionem subsistentium prima sunt imperfectiora secundis et secunda hiis que deinceps; ultima autem perfectissima.

278 Berthold of Moosburg, Expositio, Prol. 16, p. 24, l. 636 - p. 25, l. 646. 
light were Aristotle, the Liber de intelligentiis of Adam Pulchrae Mulieris, and Avicenna; on supersubstantial light, Berthold turned to Dionysius and again to Adam. For the foundational analysis of physical light, Berthold appealed to "the perspectivists" in general (probably Alhazen and Dietrich), all of whom were indebted to Aristotle's De anima II.7 and chapter 3 of his De sensu et sensato. ${ }^{279}$

Berthold's analysis of physical light centered on radiant forms (formae radiosae) and the process of propagation or radiation (radiatio). ${ }^{280}$ Light and colour are radiant forms. Unlike a physical form such as heat, which exclusively inheres in its subject, a radiant form is an inherent quality that informs its subject "in a certain order towards the outside", by which it diffuses and multiplies itself. According to Berthold, three things coincide in the process of radiation: (1) the principle, (2) the medium, and (3) the mode of propagation. His account of (1) the principle was basically Aristotelian. ${ }^{281}$ The transparency (diaphanum) as such is unbounded (interminatum). Light (lumen) is a quality received into the transparent as a form is received by its subject. Light in the transparency constitutes the transparency in act (perspicuum). ${ }^{282}$ The perspicuum is either bounded (terminatum), and as such is colour, or is compressed (conculcatum), and as such is visible light (lux visibilis); in other words, colour exists at the boundary of the transparent, while light exists in the transparent.

Berthold devoted more attention to (2) the medium and (3) mode of radiation. (2) The transparency is said to be "transmissive" of any form "because of a certain ejection of its parts from one another", and thus it is ordered to the outside (ad extra). At this point, Berthold appealed to Dietrich's notion of essential causality and stated repeatedly that a radiating form retains its nature but takes on a different mode of being (secundum aliud esse) outside its subject. Visible light thus "proceeds according to its essence outside itself, making itself

279 For an overview of perspectivist optics in Alhazen and its Western reception, see A.M. Smith, Alhacen's Theory of Visual Perception. A Critical Edition, with English Translation and Commentary, of the First Three Books of Alhacen's De aspectibus, the Medieval Latin Version of Ibn al-Haytham's Kitāb al-Manāẓir, 2 vols (Philadelphia: American Philosophical Society, 2001), vol. 1, p. lii-cxii.

280 Berthold of Moosburg, Expositio, 36A, p. 15, l.13 - p. 17, l. 8o; 37A, p. 22, l. 11 - p. 24, l. 79 .

281 Aristotle, De anima, II.7, 418a26-419b2; id., De sensu et sensato, 3, 439a12-44ob25.

282 Diaphanum and perspicuum were generally treated as synonyms, the latter being the Latin translation of the former, which was a transliteration from the Greek. Berthold, however, seems to have followed Dietrich (De iride II.4) who used diaphanum for the transparency in its potential state and perspicuum for its actualised state. 
be outside itself according to its essence, but according to another mode of being". 283

As for (3) the mode of radiation, Berthold stated that visible light diffuses itself over a spatial distance. As such, he argued, it relates by nature first to what is more distant, and consequently only to what is proximate (per prius re ipsa et ordine naturae respiciat magis distans). From this principle we could infer, for example, that prime matter is an immediate effect of the Good, whose intention would pass immediately through the entire universe as "one" or "good" until it reached the term most distant from it. Berthold underscored the point that light diffuses itself in a linear fashion, because linear movement implies the pure extrapolation of part after part (per eiectionem in distantia ut distantia inquantum huiusmodi) without the connotation of return (reditus). Such an assertion might lead us to expect that Berthold will focus more on circularity in Proposition 37, which concerns the order of conversion. But that is not what we find. He reaffirmed that the linear radiation of light indeed corresponds to procession; but for Berthold the paradigmatic example of conversion is the perpendicular incidence of a ray on a reflective surface, so that the ray is reflected directly back to its source. ${ }^{284}$

The Neoplatonic cosmological structure of procession and return is probably most frequently imagined in terms of nested circular patterns, where each moment of procession is extrinsic to each moment of conversion. According to Berthold's proposal that it be likened to the linear diffusion of a ray reflected upon itself, every moment of procession is also a conversion. This defies our temporal imagination. It is, however, a perfect analogy for the dynamics of essential causality that Berthold developed from Dietrich of Freiberg. ${ }^{285}$ Indeed, when Berthold discussed the "reflection" or conversion of "intellectual light" in $37 \mathrm{~B}$, he cited this crucial passage from Dietrich's De visione beatifica:

In the order of things that is intrinsic with regard to the disposition of essential causes and effects, the posterior are not found without the prior, nor any of those that are last without the absolutely first. Likewise, these acts, which are concepts [conceptus] that are always essentially in act,

283 Berthold of Moosburg, Expositio, 36A, p. 16, 1. 46-5o: ut eadem lux secundum substantiam sit secundum esse nature in proprio subiecto, sit autem et alibi et extra se secundum aliud esse non solum secundum aliquem effectum, sed etiam secundum suam essentiam procedens ad extra se et faciens se extra se secundum suam essentiam, sed secundum aliud esse in concernendo per se distantiam localem eorum, in quae se diffundit.

284 Berthold of Moosburg, Expositio, 37A, p. 22, l. 30 - p. 23, l. 6 o.

285 De Libera, La mystique rhénane, p. 419-423. 
and which, in each degree of their order, remain fixed by the conception [conceptione] which is their own essence, do not conceive anything without this very conception by which they conceive their productive principle, and would have no existence without it. And thus, since such things both proceed and subsist by their conception, by which they conceive their principle (and this conception is nothing else but a certain essential reflection or conversion into their very principle), it is necessary that all such principles are subsistences according to conversion, even though procession and conversion are the same in reality, just as radiation is in its own way. ${ }^{286}$

As Berthold well understood, at the level of Es, whose essence is identical with their operation, every moment of procession is equally a moment of conversion. The only difference between this mode of "radiation" and that of the Good relates to the medium. Whereas these intellectual radiant forms are diffused through a medium, which in the analogy is equivalent to the subject elaborated by the primordial causes above it, the superintellectual light of the Good presupposes no medium at all, but simply multiplies itself (multiplicans se suis processibus in omnia), and yet remains one in its multiplication (unum in multiplicatione et unum in processione). In this linear optical model, the selfcommunication of the Good in procession is timeless and identical with the conversion of intellectual creatures to the Good.

The linear diffusion and reflection of light was therefore the most adequate illustration of the exstasis divini amoris that is at the ground of the universe. As Berthold's comments on Propositions 125 and 143 reaffirm, the name "light" befits God in several ways, but most of all God's essence as Goodness. ${ }^{287}$ For just as light is the most formal and noblest of all sensible forms, and has the

286 Berthold of Moosburg, Expositio, 37B, p. 24, l. 91-97: Sicut in ordine rerum, qui est per se quantum ad dispositionem essentialium causarum et causatorum, posteriora non inveniuntur sine prioribus nec aliquid eorum, quae sunt post, sine simpliciter primo, ita isti actus, qui sunt quidam conceptus per essentiam semper in actu, quorum quilibet in aliquo gradu sui ordinis figitur sua conceptione, quae est eius essentia, nihil concipiunt sine ea conceptione, quae concipiunt suum principium productivum, sicut et nullam entitatem haberent sine eo. Et sic, cum huiusmodi res ex sua conceptione, qua concipiunt suum principium, et procedant et subsistant, ipsa autem conceptio non est nisi quaedam in ipsum suum principium essentialis reflexio sive conversio, necessarium est omnia talia principia esse subsistentia secundum conversionem, licet conversio et processio sint idem secundum rem, sicut etiam suo modo in radiatione.

287 Berthold of Moosburg, Expositio, 143L, p. 69, l. 312-314: Et ideo Dionysius in idem ponit haec duo, scilicet bonum et lumen. Pulchrum autem mediante lumen reducitur ad rationem boni, cum pulchritudo sit consonantia cum claritate. 
perfections of all visible qualities in itself in a unified and simpler way than they are in themselves, so "the Goodness of the gods" embraces all of their formal perfections or colours within itself. ${ }^{288}$ For this reason, the primordial causes can be likened to prisms refracting the Good into their respective orders. ${ }^{289}$

It may be that the image of the linearity of the diffusion of Goodness in Berthold's thought ran even deeper. We have already seen that, for Berthold, of the soul's three motions, the direct or "linear" was the highest. For the soul that moves in this way, the creatures of the world have become transparent to their divine ideas, allowing the mind to ascend rapidly through the modes of cognition until it reaches a transitory enjoyment of the intellectus adeptus and, within that reflexivity, apprehends God through non-reflexive ignorance above the mind. This ignorance, as Berthold read in Dionysius (De divinis nominibus 7.3), occurs "when the mind, having departed from everything else, and then also sending itself away, is united with the super-resplendent rays, and is illuminated hither and yon [inde et ibi] by the inscrutable depth of wisdom". 290 This is how the minds of those "who sit in darkness and the shadow of death" are illumined and filled by the rays of truth. ${ }^{291}$ When the soul is raised to the cognition of the unum animae, it becomes united to this same linear progression of the Good to and from itself by non-reflexively mirroring (inde et ibi) the paternal and providential light. In this way the microcosm will be harmonised with the macrocosm.

288 Berthold of Moosburg, Expositio, 143L, p. 68, 1. 301-308: Sicut enim lux est maxime formalis et nobilis inter omnes formas sensibiles et habet in se unite et simpliciter et excellenter perfectiones omnium qualitatum visibilium adeo, quod etiam sit hypostasis, id est formalis subsistentia, omnium colorum, ita bonitas deorum consistit in hoc, quod ipsa sola ratione suae supersubstantialitatis est pura et immixta et sic omnino formalis nihil habens vel de materia vel materiae condicionibus sibi permixtum, immo nec de aliis intentionibus formalibus essentialiter.

289 Cf. Berthold of Moosburg, Expositio, 125B, p. 149, l. 61-64: ita dii, qui sunt per se bonitates, radios bonitatis, quos copiosissime sicut supremae et provectissimae essentiae suscipiunt ad instar prime boni omnibus suis intentionibus subiectis, copiosius largiuntur essentialiter, universaliter et impausabiliter infundendo.

290 Berthold of Moosburg, Expositio, 123D, p. 129, l.152-155. The only other citation of this text is in Expositio, Praeamb. C, p. 68, l. 533-538.

291 Berthold of Moosburg, Expositio, 143L, p. 70, l. 352-357: Prime enim Deus est simpliciter prima, purissima, simplicissima et superperfectissima veritas et ratio incommutabilis omniquaque diffundens radios suos in omne verum, licet per prius superimpleat ipsos deos superintellectuali lumine et consequenter omnes supercaelestes mentes, et sic descendat usque ad illuminationem nostri, 'qui' etiam quasi 'in tenebris et umbra mortis sedemus.' Cf. Luke 1:79: illuminare his qui in tenebris et in umbra mortis sedent. 